\title{
Quasi-Rationality in Action: A Study Of Psychological Factors in Merger Decision-Making
}

\begin{abstract}
JAMES A. FANTO*
This article shows how recent behavioral and psychological literature is useful for understanding merger decision-making by conducting a psychologicallyoriented empirical study that reveals the presence of psychological motivations or factors in mega-merger decision-making. The data set is the ten largest stockfor-stock mega-mergers for each of the last three years-the heyday of the megamergers. It first situates the article in an ongoing study of the mega-merger "wave" and presents the necessary behavioral and psychological background to the empirical study. It next describes the method of the study, which involves creating a "grid" of psychological factors and applying it to public representations of decisions by the boards of the merging firms in the data set, in order to detect the presence of the factors in this decision-making. It then presents the results of the empirical study and offers a narrative explanation of them. To reinforce the shareholder value destruction in the mega-mergers, the article also provides evidence of value loss in the thirty mega-mergers. Finally, it discusses the implications of the empirical study for corporate and securities law relating to mega-merger decision-making. Here it finds that courts and policymakers accept a psychologically simplistic view of this decision-making by both boards of directors and shareholders. It also argues that both corporate law and federal securities laws require reform so that regulators and courts can address the influence of psychological factors in merger decision-making. The article concludes by offering examples of possible legal reform.
\end{abstract}

I would take issue with the idea that most mergers end up being failures. I know there are studies from the 1970s and ' 80 s that will tell you that. But when I look at many companies today-particularly new-economy companies like Cisco and WorldCom-I have a hard time dismissing the strategic power of M\&A.

-Alex Mandl, Chairman and CEO of Teligent. **.

\footnotetext{
* Professor, Brooklyn Law School. I thank Philip Lindenbaum for his research assistance, Jeffrey Rachlinski and Daniel Greenwood for valuable comments on an earlier draft, Dean Joan Wexler for a summer stipend and one-semester sabbatical, and Larry Mitchell for his invitation to the Summer 2000 Sloan Program for the Study of Business in Society, sponsored by the George Washington University Law School, which inspired the article. (C) 2001 by James A. Fanto. All rights reserved.

${ }^{* *}$ Dennis Carey (moderator), Lessons From Master Acquirers: $A$ CEO Roundtable on Making Mergers Succeed, HaRV. Bus. REV., May-June 2000, at 145, 146.
} 
Most academic studies of mergers argue that a majority of mergers are not beneficial to the acquiring company.... The overwhelming majority of negotiated strategic mergers that I have been involved in over a 45 -year period were successful for the acquiring company.

- Martin Lipton, renowned takeover lawyer. ${ }^{* * *}$

Even factually informed people tend to think that risks are less likely to materialize for themselves than for others.

-Professor Cass Sunstein
(referring to psychological literature on optimism and self-serving bias).

\section{INTRODUCTION}

By all accounts, the stock-for-stock mega-merger is the kind of transaction that characterized the 1990 s and continues to mark the first decade of the new millennium. 'The examples of this kind of transaction, where two enormous publicly owned firms combine or, in legal parlance, "merge" through an exchange of their stock, are thus numerous during the recent past. One exemplary mega-merger that comes to mind is the largest to date-the combination of the Internet firm America Online and the entertainment conglomerate Time Warner. ${ }^{2}$ Although concentrated in telecommunications, financial services, and oil, the transactions have also occurred in other industries. ${ }^{3}$

Unfortunately, the success record of the current mega-mergers, like so many predecessor transactions, is poor. Available data suggest that the transactions

\footnotetext{
${ }^{* * *}$ Martin Lipton, Mergers: Past, Present and Future 10 (Jan. 10, 2001) (unpublished manuscript, on file with author).

***** Cass R. Sunstein, Behavioral Analysis of Law, 64 U. CHI. L. REV. 1175, 1183 (1997).

${ }^{1}$ A mega-merger is generally understood to mean a merger of large firms where the acquiring and acquired or target firm are of comparable size. See Richard T. Bliss \& Richard J. Rosen, CEO Compensation and Bank Mergers 9 (Feb. 2000) (unpublished manuscript), at http://papers.ssm.com (May 28, 2000) (defining bank mega-merger as an acquisition "where the total assets of the target bank immediately before the merger announcement are at least ten percent of the acquirer's pre-merger assets and where the target is not a failed bank'); Edward J. Kane, Incentives for Banking Mega-Mergers: What Motives Might Regulators Infer from Event-Study Evidence? 20 (Jan. 25, 2000) (unpublished manuscript), at http://papers.ssm.com/sol3 (Mar. 3, 2000) (defining bank mega-merger as transaction involving one of the largest bank holding companies that increases its pro-forma size or market capitalization by at least one-half the amount of assets shown for the twelfth largest bank holding company).

${ }^{2}$ See Martin Peers et al., AOL, Time Warner Leap Borders to Plan a Mammoth Merger, WALL ST. J., Jan. 11, 2000, at A1.

${ }^{3}$ See infra Part V.D.
} 
destroy, and will continue to destroy, value for shareholders of the combined firm. The new firm will simply underperform comparable firms that have not engaged in a similar mega-transaction. This value destruction often arises because the firm fails to achieve the economies of scale or scope and other "synergies" that it promised and because nimble competitors take advantage of the new firm's efforts to bring its two parts together in order to erode its position in its product markets.

It is therefore not surprising that business and finance scholars study and try to explain the persistence of these value-destroying transactions. One popular explanation focuses on the psychological reasons for the deals. According to this account, chief executive officers (CEOs) of acquiring firms are both overoptimistic and, in many cases, hubristic in proposing and affecting the megatransactions. ${ }^{6}$ Ignoring past evidence of the probable failure of this kind of transaction and even the combination difficulties facing them in the proposed deal, top executives nevertheless believe that their transaction will be the exception to the rule and they single-mindedly push forward to implement it. Indeed, in their desire to ensure that the combination is effected, they often "bid up" the price of the target so high as to lower even more the chance of success of the merger.

It is now appropriate to move beyond the psychological explanations for destructive mergers offered in these early studies. The simple reason is that, in recent years, there has been considerable development in psychological and behavioral studies on decision-making. The rich academic literature that has emerged and that is now influencing legal studies suggests complex psychological motivations for the transactions besides managerial hubris. ${ }^{7}$ For example, although the overconfidence of CEOs no doubt plays a large part in the decision-making on the transaction and is likely to be particularly present in a mega-merger, a merger will often also be motivated by a strong fear on the part of both firms' managers and board members of losing the firms' respective competitive positions-i.e., of losing their "status quo." In behavioral terms, this

${ }^{4}$ See AlFRed D. Chandler, JR., SCALE AND SCOPE: THE DYNAMICS OF INDUSTRIAL CAPITALISM 17 (1990) (defining scale economies as "those that result when the increased size of a single operating unit producing or distributing a single product reduces the unit cost of production or distribution" and scope economies as "those resulting from the use of processes within a single operating unit to produce or distribute more than one product").

${ }^{5}$ MARK L. SIROWER, THE SYNERGY TRAP: HOW COMPANIES LOSE THE ACQUISITION GAME 6 (1997) (defining symergy as an "increase in competitiveness and resulting cash flows beyond what the two companies are expected to accomplish independently").

${ }^{6}$ For the classic discussion of this problem in mergers, see Richard Roll, The Hubris Hypothesis of Corporate Takeovers, 59 J. Bus. 197 (1986). See generally Bernard Black, Bidder Overpayment in Takeovers, 41 STAN. L. REV. 597 (1989) (providing an early summary of the psychological literature).

${ }^{7}$ See infra Part III. 
fear reflects the presence of a "status quo" bias. ${ }^{8}$

This article proposes to show how recent behavioral and psychological literature would be useful for understanding merger decision-making by conducting a psychologically-oriented empirical study, but not a psychologicallycontrolled experiment, ${ }^{9}$ that reveals the presence of psychological motivations or factors in the mega-merger decision process. It uses thirty total transactions--the ten largest announced stock-for-stock mega-mergers in 1998, 1999, and 2000. The article examines the justifications for the transactions that the combining firms offer in public documents that are credible representations of board decision-making and to which legal liability attaches. These documents include press releases announcing the transactions and combined registration and proxy statements filed with the Securities and Exchange Commission (SEC) in which both firms seek shareholder approval of the merger and the acquiring firm registers the shares used in the share exchange. In particular, the examination of this data is designed to detect the existence or nonexistence of behavioral and psychological factors that might have motivated decision-making in the megamergers.

This article does not end with presenting its empirical findings, even though by themselves they are significant for the light that they shed on decision-making in the recent mega-mergers. It discusses the findings in relation to the corporate law and federal securities law governing merger decision-making. Under this law, courts and governmental authorities, like the SEC, presume that merger decisionmaking is essentially a rational process limited generally to information processing, and they rarely intrude upon or question it provided that there are appropriate indicia of rationality in the process. If, however, behavioral and psychological factors are found to figure so prominently in merger decisionmaking, even when the process otherwise appears rational, the law's approach to regulating this process is seriously flawed. This approach is particularly troubling, moreover, if there is any empirical evidence-some of which the article provides-that the exercise of the factors correlates with value-destroying mergers. The empirical findings of the article thus suggest that both corporate and securities law need to be reformulated to take account of the reality of merger decision-making, and the article offers some examples of this reformulation.

The article proceeds as follows: Part II briefly situates the article in an ongoing study of the mega-merger "wave" and of the value destruction resulting from the stock-for-stock mega-mergers. Part III presents the necessary behavioral and psychological background of the empirical study. It first refers to the previous

\footnotetext{
${ }^{8} I d$.

${ }^{9}$ Typical psychologically-controlled experiments often involve studies that use college students (or others) as subjects in order to attempt scientifically to isolate behavioral effects. See, e.g., Jennifer Arlen, Matthew L. Spitzer \& Eric L. Talley, Endowment Effects, OtherRegarding Preferences, and Corporate Law (Apr. 21, 2000) (unpublished manuscript, on file with author).
} 
psychological explanations for problems in mergers and then surveys the contributions of recent psychological and behavioral studies that are particularly relevant for understanding merger decision-making. This survey sets forth the motivations, biases, and heuristics (shortcut ways of thinking) that make up the psychological factors common in decision-making.

Part IV presents the empirical study's method and database. It explains why the empirical approach was selected over alternative approaches and justifies the reliability of the chosen method. It next describes this method and the data set of the empirical study. The study creates a "grid" of the psychological factors and then applies it to public representations of decisions by the boards of the merging firms in thirty announced stock-for-stock mega-mergers, in which they discuss their reasons for the mergers and ask shareholders to support their merger proposal, in order to detect the presence of the factors in this decision-making. This part also answers possible objections to the method. Part V presents four tables with the results of the empirical study and then offers a narrative explanation of the results. To show that, like the typical merger, these megamergers generally destroy shareholder value, this part then presents evidence of loss of shareholder value in the thirty mega-mergers. It concludes by discussing the suggestive, but inconclusive, evidence establishing a causal relation between the psychological factors and this value destruction in the relevant mega-mergers.

Finally, Part VI discusses the implications of the empirical study for corporate and securities law relating to mega-merger decision-making. It first examines how courts, in applying this law, account for the presence of the psychological factors in this process. It finds, in fact, that they accept a psychologically simplistic view of merger decision-making by both boards of directors and shareholders. It then questions efforts by legal scholars to suggest that this simplistic judicial view actually masks a more sophisticated legal awareness of and accommodation with psychology in merger decision-making. Second, Part VI argues that both corporate and securities law require reform so that regulators and courts can address the influence of psychological factors in merger decision-making. It offers several examples of possible reform, such as a proposal that both SEC disclosure rules and Delaware's corporate law duty of disclosure be enhanced to encourage boards of companies proposing a megamerger to engage in certain decision-making steps that could help counter the influence of the psychological factors, and a related proposal requiring more disclosure from investment banks delivering fairness opinions in the transactions. Part VI also suggests that a particularly useful reform would be for courts to accord less deference to boards in merger decision-making and argues that this reform might follow from courts increasing their awareness of the role of the psychological factors in decision-making. Part VII concludes that the article's study demonstrates the forceful presence of psychological factors in merger decision-making. 


\section{AN ONGOING STUDY OF MEGA-MERGERS}

This article is the second in a series of studies of merger decision-making with a focus on mega-mergers. The first article discussed how the mega-merger is the emblematic transaction of the 1990s and early 2000 s and identified both the anecdotal and scientific evidence of the destruction of shareholder value in these transactions. ${ }^{10}$

There is no reason to revisit the issues discussed in this earlier article, particularly the available evidence of value destruction from the mega-mergers. Rather, it is important here only to emphasize a few points made in that article, which are critical to this article's empirical study, and to situate the study as part of a larger, ongoing project. First, as the term is used here and in the previous article, mega-merger means a combination of some of the largest firms in a given industry, where the target is of comparable size to the acquirer. The legal form of the transaction, moreover, is usually a merger of the target firm with a subsidiary of the acquirer where the shareholders of the target receive acquirer stock and the target firm becomes an acquirer subsidiary, the classic reverse triangular merger. ${ }^{11}$ Under corporate law (and sometimes under stock exchange rules), the board of each firm must approve the transaction and, in most cases, must seek shareholder approval for it. ${ }^{12}$ Very often the combination is presented as a "merger of equals," which means that, from the perspective of both firms, the transaction is almost a partnership. Not only do the assets, liabilities, and employees of the firms combine, but also do those groups who are the focus of corporate governancethe CEOs, board members, and shareholders.

Second, neither this article nor its predecessor is intended to deny that CEOs, board members, and their advisors have organizational and industrial justifications for and rational strategies relating to mergers. ${ }^{13}$ The literature on

${ }^{10}$ See James A. Fanto, Braking the Merger Momentum: Reforming Corporate Law Governing Mega-Mergers, 49 BUFFALO L. REV. 249, 251, 256-57 (2001). The article then offered several explanations for these transactions, particularly highlighting the psychological pressures that push CEOs to propose, and boards of directors, shareholders, and financial professionals to go along with, the transactions; the absence of political pressure on decisionmakers; corporate law jurisprudence that promotes this kind of merger as a preferred alternative to the leveraged buy-outs (LBOs) of financial raiders of the 1980s; and corporate practice that hinders "rethinking" of the transaction once boards have agreed to it. The article finally argued for a reform to Delaware corporate law that would encourage boards to resist the "momentum" of a mega-merger by having courts impose an enhanced fiduciary duty upon them when the boards are evaluating this kind of transaction.

"See Ronald J. Gilson \& BERNARd S. BlaCk, The LAW AND FNANCE OF CORPORATE ACQUISTIONS 670-71 (1995) (describing transaction structure).

${ }^{12}$ See WLlLAM J. CARNEY, MERGERS AND ACQUISTIONS 714-16 (2000) (discussing some basics of shareholder voting in triangular mergers).

${ }^{13}$ However, these justifications and strategies are not above criticism on their own economic and financial terms. See, e.g., RICARDO J. CABballero \& MOHAMMAD L. 
mergers, including mega-mergers, in the business, organizational, economic, and finance disciplines is extensive and is devoted to explaining both rational reasons for the occurrence of these transactions and rational ways of improving them. ${ }^{14}$ The literature even identifies instances when the exercise of this kind of rationality in merger decision-making can be characterized as "perverse"-for example, CEOs engage in mergers primarily to increase their own compensation or perquisites, a rational, self-interested goal. ${ }^{15}$

Third (and this is the central point of the ongoing research project), the persistence of value problems in mergers, particularly in the mega-mergers, suggests that calculative rationality may not tell the whole story about merger

Hammour, INSTITUTIONS, Restructuring, AND MACROECONOMIC PERFORMANCE 30-31 (MIT Dep't of Econ., Working Paper No. 00-02, 2000), at http:/papers.nber.org/papers/w7720 (last visited Aug. 29, 2001) (explaining that most merger and acquisition activity involving restructuring has occurred when stock prices are high because sellers are encouraged by this liquidity to sell their firms); NAM-HOON KANG \& SARA JOHANSSON, CROSS-BORDER MERGERS AND ACQUISITIONS: THEIR ROLE IN INDUSTRIAL GLOBALISATION 30-33 (OECD STI, Working Paper No. 2000/1, 2000), at http://www.oecd.org/dsti/sti/prod/wp200_le.htm (last modified Jan. 10,2000 ) (explaining industrial, firm-level, technological, and governmental reasons for crossborder mergers); RAGHURAM G. RAJAN \& LUIGI ZNGALES, THE GOVERNANCE OF THE NEW ENTERPRISE 26-27 (Nat'l Bureau of Econ. Research, Working Paper No. 7958, 2000), at http://papers.nbder.org/papers/w7958 (last visited Aug. 29, 2001) (discussing recent merger wave in "human capital" terms); Vojislav Maksimovic \& Gordon M. Phillips, The Market for Corporate Assets: Who Engages in Mergers and Asset Sales and are there Efficiency Gains? 29 (Nov. 20, 2000) (unpublished manuscript), at http://papers.ssm.com/sol3/ papers.cfm (Mar. 16, 2000) (finding that mergers tend to occur when there is a positive "demand shock" to an industry and assets and firms subsequently are purchased by the best users). But see Pankaj Ghemawat \& Fariboirz Ghadar, The Dubious Logic of Global Megamergers, HARV. BUS. REv., July-August 2000, at 63,65 (strongly questioning the economic rationale for global megamergers and pointing out that concentration in industries has actually declined over the past fifty years); Allen N. Berger et al., Globalization of Financial Institutions: Evidence from CrossBorder Banking Performance, 3 BROOKINGS-WHARTON PAPERS ON FN. SERVICES 47-50 (2000) (reviewing in detail the reason for cross-border mergers of financial institutions and finding that domestic banks are generally more efficient than foreign banks, except banks from the United States, which calls into question the absolute logic of cross-border mega-transactions in financial services); Kane, supra note 1, at 20-23 (explaining results from event studies showing post-announcement gains in value from bank mega-mergers-based on total of stock market gains from each firm on day of announcement-may be due to perceived advantages from a bank's achieving market power and "too big to fail" status, rather than to expectation of achievement of the promised synergies).

${ }^{14}$ See, e.g., Shaker A. Zahra \& Sherry S. Chaples, Blind Spots in Competitive Analysis, 7 ACAD. MGMT. EXECUTIVE 7 (1993) (discussing common flaws in executives' analysis of competitors, but also focusing on executives' psychological and cognitive limitations).

${ }^{15}$ See, e.g., Jay Hartzell et al., What's in It for Me? Personal Benefits Obtained by CEOs Whose Firms Are Acquired 10-12, 14-16 (March 2000) (unpublished manuscript), at http://papers.ssm.com/sol3/papers.cfm (July 24, 2000) (presenting data showing that target CEOs extract wealth gains from the acquirer in retum for agreeing to allow their firms to merge, with such gains being lower when the $\mathrm{CEO}$ obtains a position with acquirer). 
decision-making. That is, the frequent, spectacular failures in mergers may well point to something other than a problem in rational decision-making. A problematic merger, for example, may not result from the failure of decisionmakers to process particular information or to carry on their deliberations long enough, or from their understandable, all-too-human inability to foresee particular consequences. Rather, problems with mergers could arise from the exercise of psychological factors in the decision-makers that invariably and repeatedly cause them to react to, and to understand, information in given ways or to overlook completely information that does not support their chosen path. ${ }^{16}$

There is growing evidence that even in human activities like merger decisionmaking, where people are understood generally to exhibit rational behavior, people often think and behave not entirely in a rational manner. They do not act irrationally, but they act quasi-rationally. ${ }^{17}$ My earlier article emphasized how the prevalence of the mega-mergers owed much to psychological momentum as CEOs felt pressure to imitate competitors doing large transactions, boards felt compelled to follow persuasive CEOs who had a good acquisition track record, and financial professionals and investors went along with the momentum that the business press promoted and politicians did not oppose. ${ }^{18}$ The purpose of this article is to conduct an empirical study that helps unpack and identify the specific psychological factors that contribute to the momentum and affect merger decision-making and to consider the implications of the findings for the view of merger decision-making found in the law. A full justification for and explanation of the empirical study require a review of the relevant behavioral and psychological literature.

\footnotetext{
${ }^{16} \mathrm{~A}$ related issue, but one not addressed in this article, is how psychological issues may "make or break" the success of a merger. See, e.g., MAURIZIO ZOLLO \& DIMA LESHCHINKSKII, CAN FIRMS LEARN TO ACQUIRE? DO MARKETS NOTICE? 24 (Wharton Fin. Inst. Ctr., Working Paper No. 00-01, 2000), at http://fic.wharton.upenn.edu/fic/wfic/papers (last visited Aug. 29, 2001) (discussing how an acquirer's elimination of senior management in a target firm destroys value in the combined firm "due to the non-cooperative or even antagonistic environment which is typically established as a consequence of the perception of unfair decision-making in the integration phase").

${ }^{17}$ See RICHARD H. THALER, QUASI RATIONAL ECONOMICS xxi (1991) ("Quasi rational behavior exists, and it matters. In some well-defined situations, people make decisions that are systematically and substantively different from those predicted by the standard economic model.").

${ }^{18}$ One way in which a merger "wave" can destroy value is subtle. In essence, the wave has a "contagion" effect: the merger of one firm in turn provokes other transactions as firms scramble to keep up with one another. As a result, there is a kind of arms race to do these destructive transactions. Cf. ROBERT H. FRANK, LUXURY FEVER: WHY MONEY FAILS TO SATISFY IN AN ERA OF EXCESS 122-45 (1999) (discussing studies explaining why human behavior is highly influenced by an individual's understanding of his or her relative position in society and thus by the actions of others).
} 


\section{A REVIEW OF THE BEHAVIORAL AND PSYCHOLOGICAL LITERATURE}

In one attempt to explain the value destruction caused by mergers, particularly those of the conglomerate merger wave that occurred after World War II, legal and finance scholars turned to psychology. Finance scholar Richard Roll offered the classic explanation: CEOs are simply overconfident and hubristic regarding the transactions. ${ }^{19}$ They thus propose and complete mergers without even seeing, or accepting the probability of, a negative outcome. Related psychological research on the "winner's curse" has also been used to explain failed mergers, although usually those resulting from competitive bidding. ${ }^{20}$ Under this theory, a CEO of an acquiring firm is so eager to do a merger that he or she loses track of the limited possibility of value creation from the transaction and overbids for the target, thus assuring that the combination will ultimately fail to increase shareholder value.

Since the use of this psychological literature to account for mergers, there have been considerable behavioral and psychological studies of decision-making and a sustained and growing application of them to situations governed by the law. It is fair to say that law and psychology (or, more broadly, law and human cognition) is one of the most fertile areas of current legal and finance research. Legal scholars are paying more attention to the studies, which brings even more psychological research and insight into legal discussions. This approach has expanded across legal studies. ${ }^{21}$ Moreover, business and financial specialists are

${ }^{19}$ See supra note 6. Managerial literature on mergers continues this focus on CEO overconfidence. See, e.g., Bliss \& Rosen, supra note 1, at 18-19 (summarizing conclusion that bank CEOs increase their own compensation from mergers even when shareholders experience a loss, but offering no conclusion as to whether current bank mega-mergers are worthwhile).

${ }^{20}$ See Richard H. THALER, THE WINNER's CuRSE: PARADOXES AND ANOMALIES OF ECONOMIC LIFE 50-62 (1992).

${ }^{2 !}$ See, e.g., Russell B. Korobkin \& Thomas S. Ulen, Law and Behavioral Science: Removing the Rationality Assumption from Law and Economics, 88 CAL. L. REV. 1051, 1053 (2000) (arguing that principles in behavioral sciences such as sociology and psychology may revitalize the fading law and economics theory); Donald C. Langevoort, Behavioral Theories of Judgment and Decision Making in Legal Scholarship: A Literature Review, 51 VAND. L. REV. 1499, 1506-19 (1998) (reviewing the impact of behavioral psychology on legal literature). This new trend in legal scholarship is not free from criticism. See Mark Kelman, Behavioral Economics as Part of a Rhetorical Duet: A Response to Jolls, Sunstein, and Thaler, 50 STAN. L. REV. 1577, 1586-91 (1998) (contending that behavioral economics does not offer an adequate predictive model); Richard A. Posner, Rational Choice, Behavioral Economics, and the Law, 50 STAN. L. REV. 1551, 1552 (1998) (arguing that behavioral law and economics scholars overemphasize inrationality and that many behavioral problems can be explained by rational choice theory and evolutionary biology). But see Christine Jolls, Cass R. Sunstein \& Richard Thaler, Theories and Tropes: A Reply to Posner and Kelman, 50 STAN. L. REV. 1593, 1603-04, 1607-08 (1998) (explaining the scientific foundations of behavioral law and economics - in response to Posner-and observing - in response to Kelman-that studies have shown that the approach may result in predictions of behavior); Shira B. Lewin, Economics and 
increasingly exhibiting a behavioral and psychological orientation. ${ }^{22}$

These intellectual developments suggest that the application of a behavioral and psychological approach to merger decision-making may well increase understanding of this process. For this application, which is the purpose of the article's empirical study, it is necessary to outline (i) the general purpose of the behavioral and psychological studies and (ii) the psychological factors whose existence has been well documented in the literature. The purpose of this new approach in legal studies is to address problems arising under the dominant law and economics (L\&E) approach. Under this approach, the paradigm of human decision-making is rational choice: people rationally weigh alternatives with a dispassionate cost/benefit calculation in making decisions. ${ }^{23}$

Yet this paradigm may well be significantly flawed as a model of human behavior. Considerable empirical evidence suggests that people often do not behave in ways predicted by the model. For example, studies show that a person places more value on an object in his or her possession than what is rationally justifiable; i.e., he or she refuses to part with the object unless given a value that is in fact greater than its well-established market value. ${ }^{24}$ Behavioral and psychological studies have thus pointed to a need for an account of a person and individual decision-making different from the rational choice model in order to explain and to predict how people in fact make decisions and behave. ${ }^{25}$ This account of human behavior is critical for legal studies because laws and legal rules are often designed to affect and modify behavior, and this goal can hardly be achieved without the best available understanding of the behavior itself.

While it is impossible to do justice to the considerable psychological and behavioral research, including its applications in law and finance, it is useful to summarize briefly some of its findings to identify the psychological factors used in the empirical study. By now, a reader of law reviews can take his or her pick of articles comprehensively summarizing the literature, and there is little need for another one. ${ }^{26}$ The behavioral and psychological account offers a richer

Psychology: Lessons for Our Own Day from the Early Twentieth Century, 34 J. EcoN. LT. 1293, 1295-99 (1996) (discussing the history of economics in the 20th century and its simultaneous resistance to psychology and interest in psychology at the expense of other social sciences).

${ }^{22}$ See generally HOWARD SHEFRI, BEYOND GREED AND FEAR: UNDERSTANDING BEHAVIORAL FinANCE AND THE PSYCHOLOGY OF INVESTING (2000) (general discussion of behavioral finance); ANDREI SHLEIFER, INEFFICIENT MARKETS: AN INTRODUCTION TO BEHAVIORAL FNANCE (2000).

${ }^{23}$ Korobkin \& Ulen, supra note 21 , at 10-16 (for full explanation of versions of rational choice theory).

${ }^{24}$ THALER, QUASI RATIONAL ECONOMICS, supra note 17, at 167-88 (discussing this phenomenon, which is known as the "endowment effect").

${ }^{25}$ Jennifer Arlen, Comment, The Future of Behavioral Economic Analysis of Law, 51 VAND. L. REV. 1765, 1766 (1998).

${ }^{26}$ See, e.g., BEHAVIORAL LAW AND ECONOMics (Cass R. Sunstein ed., 2000); Christine 
description than rational choice theory of the motives for and the process of human behavior and decision-making, which may help an analyst predict human behavior and form policies likely to modify and influence it. ${ }^{27}$ This perspective understands human behavior as emotional and impulsive, rather than exclusively rational: by their nature people often focus on the present and the short term (i.e., they are "myopic"), exclude the future, and react emotionally to the present. ${ }^{28}$ Thus, they will often place inappropriate value on a present risk or attraction and find themselves either too preoccupied with or unable to resist it. ${ }^{29}$

Other behavioral phenomena deal not so much with an emotive focus on the present as with limitations on human calculative rationality itself, sometimes called "bounded rationality. ${ }^{, 30}$ Here the difference between the view of human beings offered by behavioral studies and that of the rational choice model is clear, for the former points to psychological constraints on rationality. People do not calculate rationally, but they exhibit various biases that prevent or distort rational calculation. Human beings react more strongly to losses than to gains (i.e., they have "loss aversion"). In other words, they have a bias towards the status quo and become attached to what they have (known as the "endowment effect"). ${ }^{31}$ Under

Jolls et al., A Behavioral Approach to Law and Economics, 50 STAN. L. REV. 1471 (1998); Jolls et al., supra note 21; Korobkin \& Ulen, supra note 21; Langevoort, supra note 21; Cass R. Sunstein, Behavioral Analysis of Law, 64 U. CHI. L. REV. 1175 (1997) [hereinafter Sunstein, Behavioral Analysis]; Cass R. Sunstein, Behavioral Law and Economics: A Progress Report, 1 AM. L. \& ECON. REv. 115 (1999) [hereinafter Sunstein, Behavioral Law and Economics]. If anything, there now may be too many general studies of the behavioral and psychological law field, and more specific studies in particular legal disciplines are thus needed.

${ }^{27}$ See Arlen, supra note 25, at 1767 ("Economic analysis can only be improved by incorporating a richer and more accurate view of human behavior."); Richard H. Thaler, From Homo Economicus to Homo Sapiens, 14 J. ECON. PERSP. 133 (2000) ("My predictions can be summarized quite easily: I am predicting that Homo Economicus will evolve into Homo Sapiens."). This richer description of behavior may be tied to certain "basic" ways of thinking formed in the evolution of our species. See Leda Cosmides \& John Tooby, Better than Rational: Evolutionary Psychology and the Invisible Hand, 84 AEA PAPERS \& PROC. 327, 329-30 (1994) (arguing that the mind evolved in specific ways to respond to situations facing our evolutionary ancestors). The behavioral perspective may also be more accurate because it agrees with findings of neurobiology that find considerable fault with the view that only "calculative" rationality governs human decisions. See ANTONIO R. DAMASIO, DESCARTES" ERROR: EMOTION, REASON, AND THE HUMAN BRAIN 190-91 (1994) (discussing the biological basis for reason and decision-making).

${ }^{28}$ See Korobkin \& Ulen, supra note 21, at 1113-26 (discussing the power of visceral cravings and myopia and focus on sunk costs); Sunstein, Behavioral Law and Economics, supra note 26 , at $122-23$.

${ }^{29}$ Because so much of our behavior developed in the situations facing our evolutionary ancestors, this focus on the present was likely adaptive for survival. See STEVEN PINKER, How THE MIND WORKS 42 (1997) (explaining that natural selection operates over thousands of years as people adapt to their environments).

${ }^{30}$ See, e.g., Sunstein, Behavioral Law and Economics, supra note 26, at 131.

${ }^{31}$ See Korobkin \& Ulen, supra note 21, at 1107-13; Sunstein, Behavioral Analysis, supra 
another bias, people dislike extremes in their decision-making and thus tend to select the middle ground over those extremes. ${ }^{32}$ Another bias that affects decisionmaking is the well-known over-optimism, whereby people overestimate the probability of an outcome favorable to them or exaggerate their own chances or abilities when making a decision. ${ }^{33}$ In addition, people over-weigh the probability of past outcomes. This is the classic "hindsight bias" where, in retrospect, people feel that decision-makers in the past should have predicted the outcome that was in fact not predictable given information actually available at the time. ${ }^{34}$ Accordingly, in decision-making of all kinds individuals do not always calculate in a dispassionate way, weighing the value of each choice as it is established on an impersonal market, but will likely favor particular choices or outcomes or simply assign them more weight. Again, in behavioral parlance, people act quasirationally, not rationally nor irrationally.

While biases represent limitations on rationality, there are related ways of thinking that people have adopted to deal with and to simplify decision-making. They may not always produce the best outcomes in individual cases although they may work generally well. ${ }^{35}$ These are known as "heuristics."36 For example, a person may focus on something that is noticeable to him or her as the issue deserving attention or the problem needing a solution, even if, according to the probabilistic order of importance, it should not receive this focus (the "availability" heuristic). ${ }^{37}$ The heuristic can have significant consequences, particularly regarding attention to harms or risks, when people become overly focused on a problem that is present in their consciousness, such as an airplane crash, and ignore others, such as an automobile accident, that are statistically more likely to occur. Related to this way of thinking is the heuristic of "anchoring," whereby people make judgments on the basis of a value or impression that is initially given or accepted, even if the value is arbitrary and not appropriate for the issue to be decided. ${ }^{38}$ In a similar vein, people often reason or engage in decision-making based on present cases, examples, or values from

note 26 , at $1179-81$.

${ }^{32}$ See Sunstein, Behavioral Analysis, supra note 26, at 1181-82; Sunstein, Behavioral Law and Economics, supra note 26, at 135-36.

${ }^{33}$ See Korobkin \& Ulen, supra note 21, at 1091-95; Sunstein, Behavioral Analysis, supra note 26 , at 1182-84.

${ }^{34}$ See Korobkin \& Ulen, supra note 21, at 1095-1100; Sunstein, Behavioral Law and Economics, supra note 26, at 138-39.

${ }^{35}$ People often need to simplify decision-making because it is too complex or presents problems of ambiguity. See Korobkin \& Ulen, supra note 21, at 1077-84.

${ }^{36}$ See, e.g., Sunstein, Behavioral Law and Economics, supra note 26, at 139-42.

${ }^{37}$ See, e.g., Korobkin \& Ulen, supra note 21 , at 1087-88 (observing that, under the availability heuristic, people focus on salient events in their decision-making and ignore their probability, which can lead to error if the events are not truly representative).

${ }^{38}$ See Korobkin \& Ulen, supra note 21, at 1100-02; Sunstein, Behavioral Law and Economics, supra note 26, at 141. 
which they then move away only incrementally. ${ }^{39}$

These are characteristics of individual human cognition, as is befitting a behavioral or psychological focus. It would be a mistake, however, to understand the new behavioral research as limited to this individual focus, for the social focus is also important in this research. First, the research indicates that presentation or "framing" devices may trigger the biases and emotional effects. A choice outcome can be helped along, for example, by framing the desired choice as the middle one between extremes. ${ }^{40}$ This finding implies that behavioral modification can affect large groups of people.

Second, social pressures have been shown to magnify the individual cognitive biases. For example, there exists the cascade phenomenon whereby the exercise of the availability heuristic in a few individuals spreads to others, either because others believe that the first individuals are privy to special information or because they desire to be recognized as part of a group that advocates a particular perspective. ${ }^{41}$ Indeed, the power of a group to reinforce individual cognitive limitations and even to create its own limitations is particularly relevant for decision-making in small groups, like boards of directors, which are cohesive and face difficult, stressful decisions, such as mega-mergers. ${ }^{42}$

Third, much research in social cognition is aimed at understanding "grouplevel knowledge structures," including those that might be shared by all those in an industry, that both orient and distort the thinking and behavior of decision-

\footnotetext{
${ }^{39}$ See Sunstein, Behavioral Analysis, supra note 26, at 1189-90.

${ }^{40}$ See Korobkin \& Ulen, supra note 21, at 1104-05; Sunstein, Behavioral Law and Economics, supra note 26, at 139.

${ }^{41}$ This "herd" movement need not depend upon a quasi-rational mental factor but could also be based on a rational choice of an individual. See SUSHIL BIKHCHANDANI \& SUNIL SHARMA, HeRd BEHAVIOR IN FINANCIAL MARKETS: A REVIEW 5-12 (Int'l Monetary Fund, Working Paper No. WP/00/48, 2000), at http://www.imf.org/extemal/pubs/cat (last visited Aug. 29, 2001) (explaining how "cascades" of behavior can arise from individuals' basing their decisions on others' actions either because the former interpret the actions as revealing something about the information that others possess or because they have a rational interest in hiding their own incompetence by following others).

${ }^{42}$ The socially motivated distortions of rationality are properly understood as different from, yet often supporting, individual cognitive limitations. A classic form is the "groupthink" syndrome, which is the tendency of individuals to arrive at distorted judgments because of attachment to group norms. See IRVING L. JANIS, GROUPTHINK: PSYCHOLOGICAL STUDIES OF POLICY DECISIONS AND FIASCOES 174-77 (2d ed. 1982). On the issue of conditions, such as group cohesiveness, giving rise to "groupthink," and symptoms of the group cognitive problems, see id. at 242-59. Of course, just as individuals can act rationally, groups can enhance rationality and optimal decision-making. See, e.g., James D. Westphal, Collaboration in the Boardroom: Behavioral and Performance Consequences of CEO-Board Social Ties, 42 ACAD. OF MGMT. J. 7, 20 (1999) (presenting "study [that] suggests that in fact board effectiveness and ultimately firm performance may be enhanced by close, trusting CEO-board relationships combined with moderate to high levels of CEO incentive alignment"). It is simply important to realize that groups, like individuals, do not always act rationally.
} 
making groups. ${ }^{43}$ It is thus important to recognize that the psychological and behavioral approach includes the social approach because the individual and social paradigms often interact with, and reinforce, each other. ${ }^{44}$

One must be cautious, however, about applying these psychological and behavioral insights. The appearance and strength of biases may well depend upon the context of their exercise. ${ }^{45}$ A corporate agent, for instance, might not exhibit the same "endowment effect" towards a corporate good, and, in working for his or her principal, may be less susceptible to certain biases. As a general matter, moreover, the psychological and behavioral approach may not yet be able to offer a full, theoretical explanation for complex decision-making, such as that exhibited by a board in a mega-merger. ${ }^{46}$

Yet the power of the psychological, behavioral, and social psychological research to explain human behavior should not be underestimated, even if it should be applied with caution and care, just because the application of the

${ }^{43}$ See James P. Walsh, Managerial and Organizational Cognition: Notes from a Trip Down Memory Lane, 6 ORG. SCIENCE 280, 280-321 (1995) (reviewing and summarizing literature in the managerial and organizational cognition literature); James D. Westphal \& Edward J. Zajac, Defections from the Inner Circle: Social Exchange, Reciprocity, and the Diffusion of Board Independence in U.S. Corporations, 162 ADMN. SCI. Q. 161, 178 (1997) (explaining growth of board independence in social exchange terms; board members who are also CEOs at other firms and who have experienced activism become activists themselves and "diminish their resistance [to] or even actively support such change... so as to restore balance to their social exchange relationships").

${ }^{44}$ See Timur Kuran \& Cass R. Sunstein, Availability Caiscades and Risk Regulation, 51 STAN. L. REV. 683, 711 (1999). According to the authors:

The frames through which individuals interpret a situation are generally formed socially. Their reference points for assessing gains and losses are generally given by popular conventions and communicated through conversation, not chosen by individuals autonomously. Anchors, which in principle can vary enormously across individuals, are in practice the product of social interactions and widely shared information flows.

Id. The focus on the social from the L\&E perspective also comes from current work on shared view or "norms." See generally Korobkin \& Ulen, supra note 21, at 1127-34; ROBERT C. ELLICKSON, THE EVOLUTION OF SOCIAL NORMS: A PERSPECTIVE FROM THE LEGAL ACADEMY (Yale Law Sch. Program for Studies in L., Econ., and Pub. Policy, Working Paper No. 230, 1999), at http://papers.ssm.com/sol3/papers.cfm (Nov. 28, 1999).

${ }^{45}$ For example, Professor Arlen has observed that the "endowment effect" might be reduced or "matted" when it concerns an easily available consumer good or one held for a short time. See Arlen et al., supra note 9, at 14-16.

${ }^{46}$ See Kelman, supra note 21, at 1590-91; Robert E. Scott, The Limits of Behavioral Theories of Law and Social Norms, 86 VA. L. REV. 1603, 1646-47 (2000) (criticizing simplistic legal application of behavioral theories to law). But see Korobkin \& Ulen, supra note 21 , at 1073 ("There is no doubt that a single, universally applicable theory of behavior is convenient and highly desirable. But if universality is inconsistent with sophistication and realism, legal policymakers are better off foregoing universality and, instead, creating a collection of situation-specific mini-theories useful in the analysis of discrete legal problems."). 
research to law is a developing field. Indeed, its application to specific decisionmaking situations is likely to be highly fruitful because, by identifying the various psychological factors at work, it underscores and tries to understand and explain the richness and complexity of any decision, rather than to reduce a decision to a simple, but unconvincing, rational process. ${ }^{47}$ Mega-mergers are a particularly appropriate field for this application because decision-making in these large transactions is complex. Because, moreover, this kind of decision-making has resulted in so many poor outcomes, it is critical to identify further the mental characteristics that may have led to these results. ${ }^{48}$

\section{METHOD AND DATA}

The goal of the empirical study is to identify the psychological factors (of the kind outlined above) that contribute to the momentum of mega-merger decisionmaking. ${ }^{49}$ This should be an important finding, for decision-making in a merger, particularly a mega-merger, is the archetypal example of a heightened, calculative rationality that the rational choice model would appear to explain well. ${ }^{50}$ Because

${ }^{47}$ Social scientists are also trying to improve rational decision-making. See, e.g., Jerayr Haleblian \& Sydney Finkelstein, The Influence of Organizational Acquisition Experience on Acquisition Performance: A Behavioral Learning Perspective, 44 ADMIN. SCI. Q. 29, 34-36, 51 (1999) (finding that firms may learn from acquisitions experience, but in a complex way, for they must learn to generate from past acquisitions information that is relevant to a new, but similar, acquisition and to disregard their past experience when facing a completely unique, new acquisition).

${ }^{43}$ That is, if one looks at the evidence on mergers, one is hard-pressed to say that decisionmakers have rationally learned to avoid problems in these transactions. See Korobkin \& Ulen, supra note 21 , at 1071-72.

${ }^{49}$ The study thus follows legal scholars' call for more empirical work on law and behavioral studies. See Korobkin \& Ulen, supra note 21, at 1058 ("To progress beyond the current initial stage of scholarship, legal scholars will have to conduct more empirical and experimental work of their own to test whether these hypotheses [of behavioral studies] are in fact true in the particularized settings they study.").

${ }^{50}$ Indeed, because of this rationality, some feel that organizations and groups in business are not prone to quasi-rationality. See, e.g., Langevoort, supra note 21, at 1515 ("Because corporations and other business associations are so subject to market constraints, there have been long-standing doubts as to whether psychological biases, even if robust at the individual level, are likely to have much impact on organized economic behavior."). Cf. DONALD C. LANGEVOORT, THE HUMAN NATURE OF CORPORATE BOARDS: LAW, NORMS AND THE UnINTENDED CONSEQUENCES OF INDEPENDENCE AND ACCOUNTABIITY 8 (Geo. L. Ctr., Working Paper No. 241402, 2000), at http://papers.ssm.com/sol3/papers (Sep. 18, 2000) [hereinafter LANGEVOORT, HUMAN NATURE] ("Perhaps even in the world of investing -and maybe even with respect to things like board independence-symbols matter more than we think.'). But see Korobkin \& Ulen, supra note 21, at 1071. The authors state:

Certainly, firms that make clearly suboptimal decisions routinely or in extremely important circumstances may be driven out of business, but competition in product or capital markets is rarely so perfect that a firm that occasionally makes decisions that fail to maximize 
a mega-merger is such an important event for a firm, it receives a tremendous amount of attention from the staffs of firms, CEOs, and board members, as well as from investment bankers, lawyers, and other investment professionals. ${ }^{51}$ The attention is magnified when the merger involves two large firms with widely held shares that are closely followed by investment professionals, as in a mega-merger. Given these circumstances, which would appear to eliminate all but rational reasons for the decision, it would be important to show empirically that psychological factors are also present in the decision-making. ${ }^{52}$

The method of the empirical study, however, poses difficulties. A typical psychological or social psychological experiment would involve a researcher's interaction with CEOs, board members, and shareholders in an attempt to identify and isolate the influence of psychological factors on their merger decisionmaking. However, it is difficult to obtain access to these individuals, particularly when they supervise some of the largest firms in the world and have business and legal reasons to maintain the confidentiality of their discussions, ${ }^{53}$ or when, in the case of shareholders, they are so geographically dispersed. In any event, even if a researcher could question CEOs and board members about their decision-making, he or she would be evaluating participants' views of past decisions, which would not involve a controlled experiment and which might well be influenced by hindsight bias with the participants justifying their past actions in light of the later success or failure of a merger. ${ }^{54}$ It is also difficult to separate the influence of a

profits will face bankruptcy or be taken over by firms that do maximize.

Id.

${ }^{51}$ See Dennis Carey (moderator), Lessons from Master Acquirers: A CEO Roundtable on Making Mergers Succeed, HARV. BUS. REV., May-June 2000, at 147-48 (CEOs and former CEOs speaking about mergers and acquisitions; while some of them deny the reality of the negative results of mergers, others highlight many ways in which mergers fail and admit that the transactions are risky).

${ }^{52}$ Others have suggested that behavioral biases are present in this kind of decision-making. See Ghemawat \& Ghadar, supra note 13, at 69-70 (discussing various management biases that predispose executives and boards to engage in mega-transactions: e.g., CEOs focusing only on increasing revenues, using inflated stock prices, being stuck in an industry mind-set, following the "herd behavior" of an industry, being personally committed to a deal, and trusting selfinterested advisors).

${ }^{53}$ Management scholars do conduct field research involving directors. See, e.g., Mason A. Carpenter \& James D. Westphal, The Strategic Context of External Network Ties: Examining the Impact of Director Appointments on Board Involvement in Strategic Decision Making, 44 ACAD. OF MGMT. J. (forthcoming 2001) (manuscript at 13-16) (describing a process of studying board strategic behavior by sending written questionnaires to board members, but noting that "requests for participation linked the current study with an ongoing series of surveys on top management issues conducted by a major business school to which hundreds of their peers had responded").

${ }^{54}$ Another approach is shown in JANIS, supra note 42 . He studies decision-making by members of the executive branch based on extensive analysis of reports or autobiographies of participants in the decisions and of interviews with them (e.g., decision-makers in the Cuban 
rational from a quasi-rational factor in a merger without a relatively long time period to judge the success or failure of a transaction and without controlling for all possible factors influencing a decision.

An alternative is to design an experiment that replicates in a controlled environment merger decision-making by having available people (such as law students) simulate board decisions. Aside from posing ethical problems when conducted by someone other than a trained psychologist, ${ }^{55}$ this classic psychological experiment also may not capture the richness and complexity of a real-life merger decision. ${ }^{56}$ While psychologists should continue to conduct these kinds of experiments, other approaches are available to legal scholars if the point is to establish that psychological factors play a role in mega-mergers decisionmaking.

One readily available data source for an empirical study of mega-mergers is the group of documents reflecting what CEOs and board members of each merging firm publicly say about their decision-making at or near the time of the process. ${ }^{57}$ Under federal securities laws, they are required to give their reasons for the transaction, from the announcement of the deal until its consummation, and particularly when seeking shareholder approval of the transaction..$^{58}$ Indeed, this

missile crisis). Social psychologists have made efforts to systematize his approach by, for example, evaluating and comparing the views of numerous participants in and reviewers of a particular decision. See, e.g., Philip E. Tetlock et al., Assessing Political Group Dynamics: A Test of the Groupthink Model, 63 J. PERS. \& SOC. PSYCH. 403 (1992). The problem is that similar research materials are not generally available on decisions by boards because their decisions are not of historical importance and thus do not generate much available archival materials (other than board minutes) or scholarly attention in the absence of substantial litigation. Occasionally, the decisions receive journalistic attention. See generally BLL VLASIC \& BRADLEY A. STERTZ, TAKEN FOR A RIDE: HOW DAIMLER-BENZ DROVE OFF WITH CHRYSLER (2000) (discussing management deliberations leading up to this notorious, value destroying mega-merger).

${ }^{55}$ One of the most disturbing aspects of the current interest in behavioral studies by law professors is that it may spawn inappropriate experiments on law students by people who have no real competence to conduct them.

${ }^{56}$ Even Mason Carpenter and James Westphal admit in their study of board participation in strategic decision-making that their "empirical approach does not permit a direct examination of the cognitions that mediate these relationships." Carpenter \& Westphal, supra note 53, at 29. See also Arlen, supra note 25, at 1769 ("[T] he environment in which people actually operate and make choices is far more complex than the environment of most behavioral experiments."); $i d$. at 1777 ("In addition, individuals making risky choices in the real world often are subject to more than one bias and employ multiple heuristics, with sometimes conflicting effects.").

${ }^{57}$ This empirical study is thus related to the social psychological approach where psychologists study decision-making from reports of participants in the process. See supra note 42 and accompanying text.

${ }^{58}$ See U.S. SECURTIES AND EXCH. COMM'N, FoRm S-4 (REgisTration STATEMENT UNDER SECURTIES ACT OF 1933), Item 4(a)(2) (2000), at http://www.sec.gov/divisions/corpfin/forms/s-4.htm (last modified Nov. 28, 2000) (stipulating inclusion of the "reasons of the registrant and of the company being acquired for engaging in 
federal disclosure is grounded upon a state corporate law statutory requirement that board members of a firm first approve a merger and recommend it to their shareholders. ${ }^{59}$ As a federal, if not state, legal matter, these reasons include the "beliefs" and "opinions" of the CEOs and board members. 60

There are several reasons why these documents are reliable sources of data for the presence and the exercise of psychological factors in merger decisionmaking by boards of directors. First, under both federal securities law and state corporate law, board members have legal liability for the statements, including for their expression of beliefs and opinions. ${ }^{61}$ Second, because the official SEC filings for a merger are reviewed and screened by so many people (particularly by lawyers concerned about litigation if the transaction is unsuccessful and executives worried about disclosing too much information to competitors), psychological factors must have played a role in the decision-making if evidence of their presence manages to survive the screening and appears in the SEC statements. ${ }^{62}$ Third, the psychological factors detected are not only indicative of board decision-making, but also are intended to persuade shareholders to vote for the merger in question. That is, because the SEC documents show both what influenced the CEOs and board members and what they believe should affect the shareholders, any psychological factors appearing in the documents are overdetermined and thus likely to have played a role in the decision-making. Indeed, the hypothesis here is that CEOs and board members are not cynical or manipulative. Rather, they generally believe in a merger and try to persuade others of the reasons that they themselves found persuasive. ${ }^{63}$

The empirical study is as follows: The data are the ten largest announced U.S.

the transaction"). Form S-4 is used to register the securities of an acquirer in a stock-for-stock merger and may also be used as a proxy statement to explain the transaction to target and acquirer shareholders and to seek their vote to approve it. Id. at General Instruction E.

${ }^{59}$ See RODMAN WARD, JR. ET AL., FOLK'S ON THE DELAWARE GENERAL CORPORATION LAW $\S 251$ (b) (4th ed. 2000). The focus in this article, as in the ongoing study, is on Delaware corporate law, the applicable law for corporate governance of most U.S. publicly owned firms.

${ }^{60}$ See Virginia Bankshares, Inc. v. Sandberg, 501 U.S. 1083, 1091-96 (1991) (explairing that opinions and beliefs are statements of "material fact"); see also infra Part VI.A.

${ }^{61}$ See 15 U.S.C. $\$ \S 77 \mathrm{k}, 771$ (1994); supra note 60.

${ }^{62} \mathrm{Cf}$. Edmund W. Kitch, The Theory and Practice of Securities Disclosure, 61 BROOK. L. REV. 763, 846-74 (1995) (discussing a company's reasons for secrecy when undertaking SEC mandated disclosure).

${ }^{63}$ See, e.g., JANIS, supra note 42, at 247; see also Langevoort, supra note 21 , at 1506 ("Indeed, some biases create self-fulfilling prophecies by prompting others to behave in a more favorable fashion. In this sense, using the term irrationality may convey an unnecessarily pejorative connotation."). Again, the psychological focus is not meant to deny, but only to supplement, the rational deliberative activity of board members and management, which the management literature highlights. See, e.g., Carpenter \& Westphal, supra note 53, at 26-29 (discussing findings showing that the extent of board participation in strategic decision-making depends upon board background and upon whether the state of the industry of the firm is stable or rapidly changing). 
stock-for-stock (or primarily stock) mega-mergers for each of the last three years, as identified in terms of the market value of acquirer shares offered for the target firm by appropriate market data sources. ${ }^{64}$ These are the most significant transactions in terms of dollar value, the most likely either to create or lose value because of their size, and, as noted above, the typical transaction of the late 1990s and early 2000s. The data include cross-border deals because so many contemporary transactions are cross-border. ${ }^{65}$ However, because the kind of disclosure available for non-U.S. companies is not uniform, the data set includes only cross-border stock-for-stock transactions where the acquirer is a foreign party and the target is a U.S. corporation. ${ }^{66}$

The study gathers information about the reasons for these transactions from two SEC sources. The first is the press release at the time of announcement of the merger, which is generally filed with the SEC in a Form $8-\mathrm{K} .{ }^{67}$ The second source is the Form S-4, which is used to register the acquirer shares offered in the merger. The Form S-4 is usually combined in mega-mergers with proxy statements seeking the approval of shareholders of both firms in the "joint

${ }^{64}$ To identify the top 1998 transactions, I used The Top Ten Deals of 1998, FORTUNE, Jan. 11, 1999, at 72; for 1999, Top 50 US M\&A Transactions of 1999, at http://www.thedailydeal.com (last modified Oct. 25, 2000); for 2000, 25 Largest Deals-Year to Date, at http://www.cnnfn.cnn.com/news/deals/mergers/biggest.html (Oct. 30, 2000). I cross-checked these statistics with information about the top transactions in 1998-2000 with reports available to non-subscribers from Thomson Financial Securities Data (formerly the Securities Data Company). See, e.g., Richard Peterson, The World Is Not Enough . . . To Merge, at http://www.tfsd.com (Mar. 15, 2000). I use announced, rather than completed, transactions because the study primarily concems the influence of the psychological factors on board decisions. It is thus irrelevant whether, in fact, the merger was consummated. Several mergers in the database (e.g., MCI/Sprint, GE/Honeywell) were terminated before completion.

${ }^{65}$ See Bemard S. Black, The First International Merger Wave (and the Fifth and Last U.S. Wave), 54 U. MIAMI L. REv. 799, 800 (2000) (discussing how the current merger wavewhich he identifies as running from 1993 to the present-is increasingly an international, rather than U.S., merger wave); Kang \& Johansson, supra note 13, at 7-13 (presenting statistics on cross-border mergers \& acquisitions).

${ }^{66}$ That is, if non-U.S. targets were used, there would be problems with different disclosure frameworks governing these targets, to say nothing about translation difficulties. If the target is a U.S. company, the mandated disclosure on its board's reasons for the transaction is comparable to that required for any U.S. target, and, if the acquirer is non-U.S. and is offering its stock in the transaction to this U.S. target, federal securities laws require disclosure about the acquirer's reasons for the transaction that is comparable to disclosure demanded for a U.S. acquiret. See U.S. SECURTIES AND EXCH. COMM'N, FORM F-4 (REGISTRATION STATEMENT UNDER THE SECURTIES ACT OF 1933), Item 4(a)(2) (2000), available at http://www.sec.gov/divisions/corpfin/forms/f-4.htm (last modified Jun. 27, 2001).

${ }^{67}$ See U.S. SECURIIES AND EXCH. COMM'N, FORM 8-K, General Instruction F, Items 1-2 (2000), at http://www.sec.gov/divisions/corpfin/ forms/8-k.htm (last modified Jun. 27, 2001). A : non-U.S. issuer can use Form 6-K for the same disclosure, pursuant to 17 C.F.R. $\$ \$ 240.15 \mathrm{~d}-$ 16 (2001), although no securities law liability attaches to such report. 
proxy/prospectus." ${ }^{98}$ This source includes summaries of and actual reports from third parties, such as investment bankers, who are asked to give "faimess opinions" on the transaction. ${ }^{69}$

The study then reviews this data for evidence of psychological factors in mega-merger decision-making. For the study, a grid of psychological factors based on the psychological literature summarized earlier was prepared (see Appendix A for an explanation of the factors used in the study). The documents for each merger were then examined in relation to the grid to detect the presence (or absence) and strength of the psychological factors at work in the reported decision-making in each merger. This examination resulted in a table of the psychological factors, with supporting evidence for their presence and strength, for each merger. ${ }^{70}$ From these thirty individual tables, tables on the psychological factors for mega-mergers in each year and for all three'years were generated. ${ }^{71}$

The application of the merger grid and preparation of the tables has an undeniable interpretive, textual aspect to it. Finding the presence of a particular psychological factor in the written data on merger decision-making and assessing its strength involves an interpretation of the justifications given by the firms within the framework of the merger grid, as the narrative discussion of results below will show.

Questions about the scientific or objective character of this kind of analysis can certainly be raised. With a pre-established merger grid, an analyst might be oriented towards finding examples of the factors, especially since the study involves a textual interpretation. This is an issue that affects all objective studies in psychology and social psychology. ${ }^{2}$ Admittedly, though, the factor may be more serious with this study because it lacks those disciplines' efforts to ensure objectivity. The simple response to this concern is that the data used in this study

${ }^{68}$ See FORM S-4, supra note 58, at General Instruction E.1. Whether an acquirer's shareholders must vote generally turns on the number of acquirer shares to be issued in the transaction. In sum, if an acquirer does not have enough authorized shares for issuance (often the case in a mega-merger), it must amend its certificate of incorporation to increase them, which requires a shareholder vote. Listing rules of the New York Stock Exchange and the NASDAQ require shareholder approval if a listed company issues common stock whereby either its outstanding shares or voting power will be increased by $20 \%$, other than during a public offering. N. Y. STOCK EXCH., N. Y. STOCK EXCH. LISTED CO. MANUAL § 312.03(c) (1999); NaTl. ASSOC. OF SeCURTIES DEALERS, INC. (NASD), ThE NASD MANUAL $\S 4350(\mathrm{i})(\mathrm{D})$ (i) (2000). For non-U.S. companies, the applicable document is the combined F4/proxy statement. See ForM S-4, supra note 58, at General Instruction F.

${ }^{69}$ See FORM S-4, supra note 58, at Item 4(b).

${ }^{70}$ For one example of these tables, see Appendix B. My research assistant, Philip Lindenbaum, diligently helped me prepare the tables.

${ }^{71}$ See infra Part V.A.

${ }^{72}$ See JANIS, supra note 42, at 193-94; Tetlock, supra note 54, at 417-18; Walsh, supra note 43, at 308 ("The most fundamental challenge to researchers assessing a knowledge structure is to be certain they are measuring the subject's knowledge structure and not their own."). 
is public and thus available for all to review, evaluate, and reinterpret. The study is, moreover, intended as only a first step to identify and examine psychological factors in merger decision-making. Further studies would ideally use other data sources, if such ever became available, and would involve other analysts.

Another question is whether the data actually reflect the presence of psychological factors or are simply "boilerplate" used by drafters of the registration statements, particularly the lawyers who are inclined to repeat themselves in transactional documents. There is a risk of this phenomenon affecting the data because investment bankers and lawyers, like all human beings, follow set strategies in dealing with repeated situations and they are clearly repeat players in mergers. ${ }^{73}$ Indeed, the review of the data reveals some hilarious and potentially embarrassing examples of mindless use of boilerplate in proxy/registration statements. ${ }^{74}$ Yet set statements do not necessarily suggest that the psychological factors are not present in the decision-making of a particular merger. Rather, because exercise of the psychological factors is to a great extent programmed in human beings, it would be a surprise if they were not shared by CEOs, board members, and their agents or consultants and even became standardized in the documents. ${ }^{75}$ In anv event, the data shows enough differences in the registration statements to ensure that they are not all copies of a few models.

Finally, the study includes empirical data about the success or failure of each merger in terms of the merger's effect on the acquirer's market value. It also reviews the relationship between the data on the psychological factors and the share price data.

${ }^{73}$ See generally Marcel Kahan \& Michael Klausner, Path Dependence in Corporate Contracting: Increasing Returns, Herd Behavior and Cognitive Biases, 74 WASH. U. L. Q. 347, 359-65 (1996) (discussing psychological factors that may lead lawyers to use standardized contracts and documents, even when the documents might be less beneficial for particular clients than those that the lawyers could draft anew).

${ }^{74}$ To take only one example, the description of the reasons for the merger in the proxy/registration statement for the Norwest/Wells Fargo merger at times uses identical language to that in the Banc One/First Chicago merger. To be charitable to the drafters, one could say that these documents were filed close in time (September and July 1998) and that the firms, which were all banks, may well have had the same reasons for the transactions.

${ }^{75}$ From the rational choice perspective, although lawyers and investment bankers may be seen as individuals who counter the exercise of psychological factors, such as excessive optimism, by CEOs, they also have a significant financial incentive (and thus rationally selfinterested motive) to argue strongly in favor of, and not against, the mega-mergers. See Arlen, supra note 25 , at 1784 . I suggest, moreover, that they are often swept up in the momentum of a transaction, despite (as in the case of lawyers) their legal role of waming CEOs about its risks. 


\section{TABULAR RESULTS AND ANALYSIS}

\section{A. Tabular Results}

Table 1 presents the overall results of the presence and strength of the indicated psychological factors for the thirty mergers over the three-year period. To provide more detailed information about the psychological factors specific mergers exhibited, Tables 2-4 break down the results of Table 1 for each of the three years studied.

TABLE 1

PSYCHOLOGICAL FACTORS IN MEGA-MERGERS

\begin{tabular}{|l|c|c|c|c|c|c|c|c|c|}
\hline & \multicolumn{3}{|c|}{1998 Mergers } & \multicolumn{3}{c|}{1999 Mergers } & \multicolumn{3}{c|}{2000 Mergers } \\
\hline $\begin{array}{l}\text { SACTOR } \\
\text { STRENGTH }\end{array}$ & Strong & Middle & Weak & Strong & Middle & Weak & Strong & Middle & Weak \\
\hline $\begin{array}{l}\text { Myopia (Impulses) } \\
\text { Bounded Rationality } \\
\text { Loss Aversion }\end{array}$ & 6 & 4 & & 6 & 4 & & 3 & 5 & 2 \\
\hline Extremeness Aversion & 3 & 5 & 2 & 5 & 3 & 2 & 3 & 6 & 1 \\
\hline Over-optimism & 5 & 5 & & 2 & 7 & 1 & 4 & 1 & 5 \\
\hline Anchoring & 5 & 4 & 1 & 3 & 7 & & 5 & 5 & \\
\hline
\end{tabular}


TABLE 2

PSYCHOLOGICAL FACTORS FOR 1998 MEGA-MERGERS

\begin{tabular}{|c|c|c|c|}
\hline STRENGTH & Strong & Middle & Weak \\
\hline Myopia (Impulses) & $\begin{array}{ll}\text { - } & \text { Banc One/FC } \\
\text { - } & \text { Dell Atlantic/GTE } \\
\text { - } & \text { Exxon/Mobil } \\
\text { - } & \text { Nonwest/Wells Fargo } \\
\text { - } & \text { SBC/Ameritech }\end{array}$ & $\begin{array}{ll}\text { - } & \text { AT\&T/TCI } \\
\text { - } & \text { BPIAmoco } \\
\text { - } & \text { NationsBank/BA } \\
\text { Travelers/Citicorp }\end{array}$ & \\
\hline $\begin{array}{l}\text { Bounded } \\
\text { Rationality } \\
\text { Loss Aversion }\end{array}$ & $\begin{array}{ll} & \text { AT\&T/TCI } \\
\text { - } & \text { Banc One/FC } \\
\text { - } & \text { Bell Atlantic/GTE } \\
\text { - } & \text { BP/Amoco } \\
\text { - } & \text { Exxonler/Chrysler } \\
\text { - } & \text { NationsBank/BA } \\
\text { - } & \text { NorwestWells Fargo } \\
\text { - } & \text { TravelAmeritech } \\
\text { Triticorp }\end{array}$ & & \\
\hline $\begin{array}{l}\text { Extremeness } \\
\text { Aversion } \\
\text { (italics indicate } \\
\text { fims for which the } \\
\text { aversion is } \\
\text { particularly strong) }\end{array}$ & $\begin{array}{ll}\text { - } & \text { Bell Attantic/GTE } \\
\text { - } & \text { Daimler/Chrysler } \\
& \text { Nonwest/Wells Fargo }\end{array}$ & $\begin{array}{ll}\text { - } & \text { Banc One/FC } \\
\text { - } & \text { BP/Amoco } \\
\text { - } & \text { Exxon/Mobil } \\
\text { - } & \text { NationsBank/BA } \\
\text { - } & \text { SBC/Ameritech }\end{array}$ & $\begin{array}{l}\text { AT\&T/TCI } \\
\text { Travelers/ } \\
\text { Citicorp } \\
\end{array}$ \\
\hline Over-optimism & $\begin{array}{ll}\text { - } & \text { Banc One/FC } \\
\text { - } & \text { Daimler/Chrysler } \\
\text { - } & \text { NationsBank/BA } \\
\text { - } & \text { NonwestWells Fargo } \\
\text { - } & \text { Travelers/Citicorp }\end{array}$ & $\begin{array}{ll} & \text { AT\&T/TCI } \\
\text { - } & \text { Bell Attantic/GTE } \\
\text { - } & \text { BP/Amoco } \\
\text { - } & \text { Exxon/Mobil } \\
\text { - } & \text { SBC/Ameritech }\end{array}$ & \\
\hline Anchoring & $\begin{array}{ll}\text { - } & \text { Banc One/FC } \\
\text { - } & \text { Bell Atlantic/GTE } \\
\text { - } & \text { NationsBank/BA } \\
\text { - SBC/Ameritech }\end{array}$ & $\begin{array}{ll} & \text { AT\&T/TCl } \\
\text { * } & \text { Daimler/Chrysler } \\
\text {. } & \text { Exxon/Mobil } \\
\text { Norwest/Wells- } \\
\text { Fargo }\end{array}$ & $\begin{array}{l}\text { Travelers/ } \\
\text { Citioorp }\end{array}$ \\
\hline
\end{tabular}

NOTE: $\mathrm{BA}=$ Bank of America; $\mathrm{FC}=$ First Chicago. 


\section{TABLE 3}

\section{PSYCHOLOGICAL FACTORS FOR 1999 MEGA-MERGERS}

\begin{tabular}{|c|c|c|c|}
\hline $\begin{array}{l}\text { STRENGTH } \\
\text { FACTOR }\end{array}$ & Strong & Middle & Weak \\
\hline Myopia (Impulses) & $\begin{array}{ll}\text { - } & \text { Aegon/Transamerica } \\
\text { - } & \text { AT\&TMediaOne } \\
\text { - } & \text { BP Amoco/ARCO } \\
\text { - } & \text { PfizerM-L } \\
\text { - } & \text { QwestUS West } \\
\text { - } & \text { MCI/Sprint }\end{array}$ & $\begin{array}{ll}\text { - } & \text { Clear Channel/AMFM } \\
\text { - } & \text { Dow/Union Carbide } \\
\text { - } & \text { Lucent/Ascend } \\
\text { - } & \text { Viacom/CBS }\end{array}$ & \\
\hline $\begin{array}{l}\text { Bounded Rationality } \\
\text { Loss Aversion }\end{array}$ & $\begin{array}{ll}\text { - } & \text { Aegon/Transamerica } \\
\text { - } & \text { Clear Amoco/ARCO } \\
\text { - } & \text { Pfizer } M-L \\
\text { - } & \text { Qwest/US West } \\
\text { - } & \text { Viacom/CBS } \\
\text { MCl/Sprint }\end{array}$ & $\begin{array}{ll}\text { - } & \text { AT\&T/MediaOne } \\
\text { - } & \text { Dow/Union Carbide } \\
\text { Lucent/Ascend }\end{array}$ & \\
\hline $\begin{array}{l}\text { Extremeness } \\
\text { Aversion } \\
\text { (italics indicate firms } \\
\text { for which the aversion } \\
\text { is particularly strong) }\end{array}$ & $\begin{array}{ll}\text { - } & \text { BP AmocolARCO } \\
\text { - } & \text { Clear Channel/AMFM } \\
\text { - } & \text { Pfizer/W-L } \\
\text { - } & \text { QwestUS West } \\
\text { MCl/Sprint }\end{array}$ & $\begin{array}{ll}\text { - } & \text { Aegon/Transamerica } \\
\text { - } & \text { AT\&T/MediaOne } \\
\text { - } & \text { Lucent/Ascend }\end{array}$ & $\begin{array}{l}\text { Dow/ } \\
\text { Union } \\
\text { Carbide } \\
\text { Viacom/ } \\
\text { CBS }\end{array}$ \\
\hline Over-optimism & $\begin{array}{l}\text { - QwestruSWest } \\
\text { - MCl/Sprint }\end{array}$ & $\begin{array}{ll}\text { - } & \text { Aegon/Transamerica } \\
\text { - } & \text { AT\&T/MediaOne } \\
\text { - } & \text { Dow/Unoco/ARCO } \\
\text { - } & \text { Lucent/Ascend } \\
\text { - } & \text { PizerM-L } \\
\text { - Viacom/CBS }\end{array}$ & $\begin{array}{l}\text { Clear } \\
\text { Channel/ } \\
\text { AMFM }\end{array}$ \\
\hline Anchoring & $\begin{array}{ll} & \text { Clear Channel/AMFM } \\
\text { - } & \text { Pfizer } W \text {-L } \\
& \text { MCI/Sprint } \\
\end{array}$ & $\begin{array}{ll}\text { - } & \text { Aegon/Transamerica } \\
\text { - } & \text { AT\&T/MediaOne } \\
\text { - } & \text { Dow/UnocolARCO Carbide } \\
\text { - } & \text { Lucent/Ascend } \\
\text { - } & \text { Qwest/US West } \\
\text { Viacom/CBS }\end{array}$ & \\
\hline
\end{tabular}

NOTE: $A R C O=$ Attantic Richifield Co.; W-L = Wamer-Lambert 
TABLE 4

PSYCHOLOGICAL FACTORS FOR 2000 MEGA-MERGERS

\begin{tabular}{|c|c|c|c|}
\hline $\begin{array}{l}\text { STRENGTH } \\
\text { FACTOR }\end{array}$ & Strong & Middle & Weak \\
\hline Myopia (Impulses) & $\begin{array}{l}\text { - Chase/J.P. Morgan } \\
\text { - JDS/SDL } \\
\text { - Chevron } / \text { Texaco }\end{array}$ & $\begin{array}{ll}\text { - } & \text { AOLTime Wamer } \\
\text { - Citigroup/ } \\
\text { Associates } \\
\text { Deutsche Tel./ } \\
\text { VoiceStream } \\
\text { - VeriSign/Network } \\
\text { - Firstar/U.S. } \\
\text { Bancorp }\end{array}$ & $\begin{array}{ll}\text { ElPasol } \\
\text { Coastal } \\
\text { - GEJ } \\
\text { Honeywell }\end{array}$ \\
\hline $\begin{array}{l}\text { Bounded Rationality } \\
\text { Loss Aversion }\end{array}$ & $\begin{array}{ll}\text { - } & \text { AOLTime Wamer } \\
\text { - } & \text { Chase/J.P. Morgan } \\
\text { - } & \text { EIPasolNoiceStm } \\
\text { - JDS/SDL } \\
\text { - Chevron/Texaco } \\
\text { - Firstar/U.S. Bancorp } \\
\text { GE/Honeywell }\end{array}$ & $\begin{array}{ll}\text { - } & \text { Citigroup/ } \\
\text { Associates } \\
\text { - VeriSign/Network }\end{array}$ & \\
\hline $\begin{array}{l}\text { Extremeness } \\
\text { Aversion } \\
\text { (italics indicate fims } \\
\text { for which the aversion } \\
\text { is particularly strong) }\end{array}$ & $\begin{array}{ll} & \text { D Tel.JVoiceStrm } \\
\text { - } & \text { JDSISDL } \\
\text { - Chevron/Texaco }\end{array}$ & $\begin{array}{ll}\text { - } & \text { AOUTIme Wamer } \\
\text { - Chase/J.P. Morgan } \\
\text { - } & \text { Citigroup/ } \\
\text { - } & \text { ElPaciates } \\
\text { - } & \text { VeriSign/Noastal } \\
\text { - } & \text { GE/Honeywell }\end{array}$ & $\begin{array}{l}\text { " Firstarl } \\
\text { U.S. } \\
\text { Bancorp }\end{array}$ \\
\hline Over-optimism & $\begin{array}{ll} & \text { AOLTW } \\
\text { - } & \text { Chase/J.P. Morgan } \\
\text { - } & \text { Chevron/Texaco } \\
\text { - } & \text { Firstar/U.S. Bancorp }\end{array}$ & $\begin{array}{ll}\text { - } & \text { Citigroup/ } \\
& \text { Associates }\end{array}$ & $\begin{array}{ll}\text { DTel.J } \\
\text { VoiceStmm } \\
\text { - } \quad \text { El Pasol } \\
\text { Coastal } \\
\text { - JDS/SDL } \\
\text { - VeriSign/ } \\
\text { Network } \\
\text { - GEI } \\
\text { Honeywell }\end{array}$ \\
\hline Anchoring & $\begin{array}{ll}\text { - } & \text { AOLTime Wamer } \\
\text { - } & \text { Citigroup/Associates } \\
\text { - } & \text { Chevron/Texaco } \\
\text { - } & \text { El Paso/Coastal } \\
\text { - } & \text { Firstar/U.S. Bancorp }\end{array}$ & $\begin{array}{ll} & \text { Chase/J.P. Morgan } \\
\text { - } & \text { D Tel.NoiceStrm } \\
\text { - JDS/SDL } \\
\text { - } \\
\text { - } \text { GeriSign/Network } \\
\end{array}$ & \\
\hline
\end{tabular}

NOTE: D Tel.NoiceStrm = Deutsche Telekom $/$ VoiceStream 


\section{B. Analysis of Individual Responses}

The following discussion describes the kind of textual evidence that the study found indicative of the presence and strength of the psychological factors in the data set.

\section{Myopia}

This factor is difficult to extract from a documentary record of decisionmaking because, as noted earlier, it suggests that for impulsive, emotional reasons, a present event or circumstance inordinately influences decision-making. In mega-merger decision-making, this factor could be indicated by the essentially reactive nature of the transaction as a response to an industry shock or a trend that is viewed as path-breaking, that shakes up an industry, and that spurs further industry consolidation. ${ }^{76}$ The breakdown in Tables 1-4 demonstrates that if a recent shock cause of a mega-merger is repeatedly mentioned, the merger receives a "strong" characterization on myopia; if the cause is mentioned only in passing and other non-shock causes, such as firm strategies, receive more attention, the transaction has a "middle" label; and if no external event is described as having led to the transaction or if such an event is mentioned only in passing, the deal receives a "weak" designation (suggesting that, in some cases, the factor is absent).

"Strong" is the most common characterization, which is not surprising in light of the common understanding in business studies that mergers generally are due to industry shocks. ${ }^{77}$ The myopia of the strong characterization is demonstrated by repeated references in the SEC documents on a given megamerger to recent industry consolidation and competitor mega-mergers, with less emphasis given to the underlying causes of the consolidation, such as a regulatory or technological change or some other shock. ${ }^{78}$ This presentation characterizes

${ }^{76}$ A firm's "myopic" focus on competitors' mergers is often cited anecdotally as a reason for the value destruction in a given merger. See, e.g., Michael Amdt et al., Let's Talk Turkeys, Bus. WK., Dec. 11, 2000, at 44, 46 ("Many duds are 'me-too mergers' that cost way too much.").

${ }^{\pi}$ See supra note 13.

${ }^{78}$ But see JDS UNIPHASE CORP., REGISTRATION STATEMENT ON FORM S-4 5 (2000) [hereinafter JDS/SDL FORM S-4] (with respect to the SDL merger, "JDS Uniphase and SDL are proposing the merger in response to unprecedented growth in the telecommunications industry and demand for the fiber optic networks that are enabling such growth."). This focus on competitor action echoes a finding in the social cognition literature that many CEO decision errors are due to the excessive attention paid to the actions of a few firms that the CEO considers to be similar to his or her firm. See Zahra \& Chaples, supra note 14, at 13-14; see also Joseph F. Porac \& Howard Thomas, Taxonomic Mental Models in Competitor Definition, 15 ACAD. MGMT. REV. 224, 233 (1990). 
many banking and telecommunications mega-mergers in the data set, ${ }^{79}$ as well as oil industry mergers, which have as one cause the industry shock of low prices. ${ }^{80}$ Indeed, the myopic attention to a firm's competitors becomes even more pronounced when a firm secures a merger partner over competition with a rival industry bidder. ${ }^{81}$

A "middle" myopic characterization is given when the applicable SEC documents mention industry consolidation in passing and present the merger as driven by other purposes, such as the development or advancement of new technology, a new technological gamble, or an innovative cross-industry combination. ${ }^{82}$ In other cases, a first merger will have this characterization, but later mergers in the industry, stressing an industry consolidation that has been triggered or pushed along by the first merger, have a strong myopia rating. ${ }^{83} \mathrm{~A}$

${ }^{79}$ See, e.g., CHASE MANHATtAN Co., REgistration STATEMENT ON FORM S-4 28 (2000) [hereinafter CHASE/J.P. MORGAN FORM S-4] (discussing the J.P. Morgan merger: "During the past several years the financial services industry has undergone a significant consolidation. As a result, our principal competitors in many of our most important business lines have become global in size and in range of product offerings."); SBC COMMUNICATIONS, INC., REGISTRATION STATEMENT ON FORM S-4 21-22 (1998) [hereinafter SBC/AMERITECH FORM S4] (mentioning how the Telecommunications Act of 1996 "helped lead to rapid change in the telecommunications industry").

${ }^{80}$ This factor was especially noticeable in 1998. For example, Arco characterized its merger with BP Amoco as follows: "ARCO's management believes that the largest worldwide oil and gas companies, such as Royal Dutch/Shell, BP Amoco, and the proposed combined Exxon/Mobil, have the scale and diversity of operations, financial strength and intemational presence that allow them to pursue the most profitable projects and to achieve superior financial results." ATLANTIC RICHFIELD, SCHEDULE 14A 23 (1999) [hereinafter ARCO/BP AMOCO SCHEDULE 14A] (for BP Amoco merger).

${ }^{81}$ See, e.g., QWEST COMMUNICATIONS INT'L, INC., AMEND. No. 2 TO REGISTRATION STATEMENT ON FORM S-4 I-11 (1999) [hereinafter QWEST/US WEST FORM S-4] (discussing competition from Global Crossing for U.S. West merger); PFIZER, INC., AMEND. NO. 2 TO REGISTRATION STATEMENT ON FORM S-4 I-45-46 (2000) [hereinafter PFIZER/WARNERLAMBERT FORM S-4] (discussing competing transaction proposed between Wamer-Lambert and American Home Products for Wamer-Lambert merger).

${ }^{82}$ See, e.g., AT\&T CORP., REGISTRATION STATEMENT ON FORM S-4 31 (1999) [hereinafter AT\&T/TCI FORM S-4] (explaining, for TCI merger, benefits of the combination of long distance and cable, which also responded to industry consolidation); DEUTSCHE TELEKOM AG, REGISTRATION STATEMENT ON FORM F-4 1 (2000) [hereinafter DEUTSCHE TELEKOM/VOICESTREAM FORM F-4] (establishing worldwide platform for GSM services through the VoiceStream merger); TRAVELERS GROUP, INC., REGISTRATION STATEMENT ON FORM S-4 19 (1998) [hereinafter TRAVELERS/CITICORP FORM S-4] (discussing linkage of insurance and banking products in Citicorp merger).

${ }^{83}$ Compare AMOCO CORP., SCHEDULE 14A 31 (1998) [hereinafter BP/AMOCO SCHEDULE 14A] (middle myopia characterization for British Petroleum merger), with EXXON CORP., REGISTRATION STATEMENT ON FORM S-4 I-19 (1999) [hereinafter EXXON/MOBIL FORM S-4] (strong myopia characterization for Mobil merger). This trend is seen in bank mergers, although they always focus prominently on industry consolidation. Compare NATIONSBANK CORP., $\begin{array}{lllllll}\text { REGISTRATION STATEMENT ON } & \text { FORM } & \text { S-4 } & 37 & \text { (1998) [hereinafter }\end{array}$ 
middle characterization also occurs where there are few mega-mergers in a particular industry, although there may be smaller transactions. ${ }^{84}$ Finally, myopia is rarely "weak"; in such cases, the transaction appears to be completely strategic. ${ }^{85}$

\section{Loss Aversion, "Status Quo" Bias}

Repeated statements that the mega-merger does not change the existing features of the combining firms, or is a change justified by an effort not to lose one firm's or both firms' competitive position(s), give a transaction a "strong" characterization on this psychological factor. Less emphasis in the SEC data results in a "middle" label, with little or no indication leading to a "weak" characterization.

It is not surprising that so many mega-mergers in the data set exhibit the characteristic of loss aversion or status quo bias in the "strong" form (ten in 1998, seven in 1999, and eight in 2000). Many of them, particularly in banking and telecommunications, are presented as merger-of-equals transactions, which by definition maintain the status quo of each firm, albeit in a revised form. The firms are combined in a pseudo-partnership where much about each firm endures, such as some management and board members and all shareholders. Indeed, evocation of the bias makes a mega-merger psychologically compelling in the decision-

NATIONSBANK/BANKAMERICA FORM S-4] (middle myopia characterization for BankAmerica merger), with NORWEST CORP., REGISTRATION STATEMENT ON FORM S-4 22 (1998) [hereinafter NORWEST/WELLS FARGO FORM S-4] (strong characterization for Wells Fargo merger, particularly given the following discussion of the origin of the transaction: "Following the April 1998 announcements of merger agreements between NationsBank Corporation and BankAmerica Corporation, and between Banc One Corporation and First Chicago NBD Corporation, such a review [about business combinations] was conducted at the regularly scheduled meeting of the Wells Fargo Board on April 16, 1998."). But see CITIGROUP, INC., REGISTRATION STATEMENT ON FORM S-4 16 (2000) [hereinafter CITIGROUP/ASSOCIATES FORM S-4] (middle characterization for Associates First Capital merger); U.S. BANCORP, REGISTRATION STATEMENT ON FORM S-4 20 (2000) [hereinafter FIRSTAR/U.S. BANCORP FORM $\mathrm{S}-4]$ (middle characterization for Firstar merger, with Firstar being the acquirer). Perhaps, as time goes on, a consolidation focus will become standard in the industry (and accepted in all board decision-making) and thus will not receive much attention in a mega-merger's SEC documents.

${ }^{84}$ See, e.g., ClEAR CHANNEL COMMUNICATIONS, INC., REGISTRATION STATEMENT ON FORM S-4 I-1 (2000) [hereinafter CLEAR CHANNEL/AMFM FORM S-4] (broadcasting); DOW CHEMICAL Co., REGISTRATION STATEMENT ON FORM S-4 20 (1999) [hereinafter DOW/UNION CARBIDE FORM S-4] (chemicals).

${ }^{85}$ See, e.g., EL PASO ENERGY CORP., AMEND. NO. 1 TO FORM S-4 (2000) [hereinafter EL PASO/COASTAL FORM S-4] (weak myopia for Coastal merger); GENERAL ELECTRIC CO., REGISTRATION STATEMENT ON FORM S-4 (2000) [hereinafter G.E./HONEYWELL FORM S-4] (weak myopia for Honeywell merger). This weak "myopia" may augur well for the success of these transactions. See infra Part V.C. \& D. 
making of CEOs, board members, and shareholders and even in the perspective of other parties who have no vote on a transaction, but whose views could affect its consummation.

One important group is employees of both firms who are being reassured that they will not immediately lose their positions in the mega-merger. ${ }^{86}$ Also, financial professionals must be convinced that the mega-merger is not undermining the strengths of the two merging firms. In addition, regulators are also clearly addressees of this bias. In particular, antitrust regulators must be made to understand that the merger does not change the existing competitive situation in a prohibited way.

The indications of the status quo bias range from the general to the specific. A common sign that has both a rational and quasi-rational side is the frequent reference to the merging firms' "complementary" businesses, with the suggestion that the firms will each continue in the new entity. ${ }^{87}$ Another sign emphasizes the compatibility of the two firms and their sharing of culture, visions, and/or strategies. ${ }^{88}$ The complementary and compatible indications are often joined. ${ }^{89}$

\footnotetext{
${ }^{86}$ For example, middle management executives have to be assured that they will not lose their position or at least that they will still be able to compete for the same or higher positions in the new firm through the "tournament life" that characterizes business. See Langevoort, supra note 50 , at 12 " "I have long suspected that a portion of what is often described as an often unprofitable 'acquisition bias' among American corporations is in fact driven by senior managers' desire-conscious or not-to benefit the talented subordinate executives in the firm.")

${ }^{87}$ See, e.g., AEGON N.V., REGISTRATION STATEMENT ON FORM F-4 18 (1999) [hereinafter AEGON/TRANSAMERICA FORM F-4] (discussing "complementaries" for Transamerica merger); MCI WORLDCOM INC., AMEND. NO. 1 TO REGISTRATION STATEMENT ON FORM S-4 44 (1999) [hereinafter MCI WORLDCOM/SPRINT FORM S-4] (for Sprint merger, speaking about the companies' "complementary" technologies of hard wire and wireless communications). The emphasis on this word may have an antitrust implication: i.e., if the businesses are complementary, they will present no anti-competitive threat under antitrust laws. See Matt Murray, GE's Welch Makes Case for Acquisition of Honeywell and Delayed Retirement, WALL ST. J., Oct. 24, 2000, at A10 (quoting GE's Jack Welch in his justifications for the GE/Honeywell merger).

${ }^{83}$ See, e.g., Press Release, Exxon/Mobil, Exxon and Mobil Sign Merger Agreement (Dec. 1, 1998), at http://www.businesswire.com (Dec. 1, 1998) (in joint statement CEOs point out that the "merger brings together two outstanding organizations that share common values, have compatible strategies and demonstrated track records of achievement") (emphasis added); CHEVRON CORP., REGISTRATION STATEMENT ON FORM S-4 20 (2001) [hereinafter CHEVRON/TEXACO FORM S-4] ("In addition, Chevron and Texaco share common corporate values. These values include protection of the environment, active support for the communities where we operate, and promoting diversity and opportunity in our workforce and among our business partners.').

${ }^{89}$ See, e.g., FIRSTAR/U.S. BANCORP FORM S-4, supra note 83, at 23 (speaking of the "complementary nature" of the businesses and the "common vision" of management); NATIONSBANK/BANKAMERICA FORM S-4, supra note 83, at 42 (giving, as a reason for the merger, "the belief of BankAmerica's senior management and of the BankAmerica Board that
} 
The continuation of the status quo is also given tangible proof in the numerous gestures for which many mega-mergers-of-equals are well known. Often the continuation of a target's name and its headquarters is promised and highlighted. ${ }^{90}$ These gestures as signs of no change in the status quo are particularly important in cross-border mergers where, for public relations and political reasons, the continuing U.S. existence of the target must be emphasized. The Daimler/Chrysler merger is the best and, in light of its subsequent history, most notorious example. ${ }^{11}$ Well-known signs of the status quo, because of the frequency with which they break down, are the often-detailed arrangements about the continuation of management and board members of each firm. ${ }^{92}$

NationsBank and BankAmerica share a compatible culture and that their managements possess complementary skills and expertise") (emphasis added). release:

${ }^{90}$ Exemplary in this regard is the following statement from SBC \& Ameritech's press

In fact, SBC made a commitment to Ameritech that employment levels in the five-state region will not be reduced due to the transaction, as well as to:

- maintain Ameritech's headquarters in Chicago and its state headquarters in its traditional states of Illinois, Indiana, Michigan, Ohio and Wisconsin;

- continue to use the Ameritech name in each of its operating states;

- continue to support economic development and education in Ameritech's region consistent with its well-established commitment; and

- continue Ameritech's historic levels of charitable contributions and community activities.

Press Release, SBC Communications Inc./Ameritech, SBC Communications and Ameritech to Merge (May 11, 1998), at http://www.sbc.com/ News_Center (May 11, 1998); see also Press Release, Chase Manhattan Corp.J.P. Morgan, Chase and Morgan Agree to Merge (Sept. 13, 2000), at http://www.jpmorgan.com/CorpInfo/PressReleases/2000 (Sept. 13, 2000) (observing that the new firm will be known as J.P. Morgan Chase \& Co., despite the fact that J.P. Morgan was the target); Charles Gasparino \& Jathon Sapsford, As Morgan Persisted in Clinging to Its Past, Time Finally Ran Out, WALl ST. J., Oct. 19, 2000, at A1 (emphasizing the importance to J.P. Morgan executives of retaining the firm's name). There are, of course, strategic marketing considerations in the choice of a name. See, e.g., NORWEST/WELLS FARGO FORM S-4, supra note 83, at 24 ("We will take advantage of one of the most venerable names in banking: as part of the merger, Norwest will be renamed 'Wells Fargo \& Company."').

${ }^{91}$ See, e.g., DAIMLER/CHRYSLER AG, REGISTRATION STATEMENT ON FORM F-4 16-17 (1998) [hereinafter DAIMIER/CHRYSLER FORM F-4]; AEGON/TRANSAMERICA FORM F-4, supra note 87, at 17. For more information on the post-merger dispute between Daimler/Chrysler and Kirk Kerkorian, one of its largest shareholders, see Kerkorian Sues Daimler Chrysler, available at http://www.cnnfn.cnn.com/2000/11/27/news/chrysler (Nov. 27, 2000) (describing Kerkorian's claim that Daimler never intended for the merger to be a "merger-of-equals").

${ }^{92}$ The examples of the arrangements are numerous. See AOL TME WARNER INC., REGISTRATION STATEMENT ON FORM S-4 37 (2000) [hereinafter AOL/TME WARNER FORM S4] (for Time Wamer merger, explaining that the CEO of AOL becomes Chairman of the new company; that Time Wamer's CEO becomes CEO of the new company; that there will be a sixteen member board with eight members drawn from each company; that this arrangement must remain for one year after the merger; and that no change in board size can occur without a 
The data also shows that the use of loss aversion indicates that the status quo is being preserved in a complex way. Merging firms often suggest both that they are not really changing themselves and that they have to incur the enormous risks involved in a mega-merger so as to preserve in the future things as they are now -the "loss aversion." Indeed, the most psychologically forceful way of justifying the transaction, which often goes hand in hand with myopia, is to state that the merger is necessary for each firm to survive in a competitive industry and that, if the transaction is not undertaken soon, both firms may not be able to continue as industry leaders. ${ }^{93}$ A less forceful example of this approach is simply to describe the transaction as demanded by diversification to address potential (but not immediate) losses arising from industry cycles. ${ }^{94}$ Loss aversion and status

$75 \%$ vote of existing board until the end of 2003); QWEST/US WEST FORM S-4, supra note 81, at I-5-6 (describing arrangement with its three CEOs); VIACOM INC., REGISTRATION STATEMENT ON FORM S-4 8 (1999) (describing elaborate govemance arrangements for CBS merger with a board of ten members from Viacom and eight from CBS; with the Chairman and CEO of Viacom remaining and CBS's CEO becoming President and COO; and with the governance arrangement remaining generally stable for three years). Naturally, this latter arrangement had a rational explanation-Mr. Redstone of Viacom would dominate the combined company, and thus CBS needed some assurance of continuation of its own management post-merger. The "blowups" of these arrangements have become notorious. See Rick Brooks et al., Ousting of Coulter Isn't the Only Fracture at New BankAmerica, WALL ST. J., Oct. 23, 1998, at A1 (describing ouster of co-CEO of BankAmerica); David Weidner, Citigroup's John Reed to Step Down, at http:/www.thedailydeal.com (last visited Aug. 17, 2001) (describing departure of co-CEO of Citigroup).

${ }_{93}$ For example, Bell Atlantic and GTE made the following observation (so common in telecommunications mergers):

The telecommunications industry continues to change dramatically as a result of developments in technology, regulation, consumer needs and the range of product offerings made possible by these changes. In this new environment, a select group of national and international companies that offer a full range of local and long distance, voice and data services will be the most effective competitors in the telecommunications industry. We believe our proposed merger will create a powerful competitor in this dynamic, emerging market.

BELl ATLANTIC CORP., REGISTRATION STATEMENT ON FORM S-4 I-1(1999) [hereinafter BELL ATLANTIC/GTE FORM S-4] (for GTE merger). AT\&T/TCI made a similar statement on their Form S-4:

Because it is widely anticipated that substantial numbers of long-distance customers will seek to purchase local, long-distance and other services from a single carrier as part of a combined or full-service package, AT\&T believes that the ability to offer all such services at competitive rates using its own facilities will be increasingly important.

AT\&T/TCI ForM S-4, supra note 82, at 31. Cf. Jeffrey J. Rachlinski, Heuristics and Biases in the Courts: Ignorance or Adaptation?, 79 OR. L. REV. 61, 99-100 (2000) (discussing the difficulty of courts spotting cognitive biases in their own decision-making).

${ }^{94}$ See CHASE/J.P. MORGAN FORM S-4, supra note 79, at 28 ("The combined company would be broadly diversified across a number of wholesale and retail financial services 
quo bias intertwine in a presentation indicating that the firms share a compatible, but risky, strategy and that the mega-merger thus allows them to share the risk. ${ }^{95}$

Five transactions that are more clearly acquisitions, as opposed to megamergers-of-equals, have a middle characterization of loss aversion and status quo bias, although the categorization is subjective because the cases are close. These transactions are the AT\&T/MediaOne, Dow Chemical/Union Carbide, and Lucent/Ascend mergers in 1999 and the Citigroup/Associates and Verisign/Network mergers in 2000 . The middle designation is given because the target's status quo bias is downplayed. The target firm must be subsumed into the acquirer for the benefit of target shareholders, and the acquirer simply talks about the merger as a continuation of its strategy-a presentation that is not necessarily as psychologically compelling. ${ }^{96}$ In similar circumstances, however, the characterization can be "strong" when both the loss aversion to the target and the merger as a continuation of the acquirer's strategy (status quo bias) are stressed. ${ }^{97}$ Yet other acquisition-oriented mega-mergers emphasize the status quo bias for different reasons. ${ }^{98}$

businesses. This diversification would be expected to provide a more stable revenue stream through changing economic cycles and volatile securities markets."); FiRSTAR/U.S. BANCORP FORM S-4, supra note 83, at 23 (explaining both boards' support for the merger because of, inter alia:

[O]ur expectation that the combined company would benefit from significantly greater scale than either Firstar or U.S. Bancorp separately in its consumer banking, commercial banking, asset management, payment systems and in other high-growth specialty businesses, from a more diversified revenue stream and from leveraging Firstar's business model through the U.S. Bancorp franchise, including its faster-growing retail markets[.]).

${ }^{95}$ See BELL ATLANTIC/GTE FORM S-4, supra note 93, at I-25 ("The merger also mitigates the risks, capital outlays and deployment times that would be required for GTE and Bell Atlantic to develop these complementary assets and capabilities independently.').

${ }^{96}$ See, e.g., AT\&T CORP., REGISTRATION STATEMENT ON FORM S-4 II-6 (1999) [hereinafter AT\&T/MEDIAONE FORM S-4] (for MediaOne merger); CTTIGROUP/ASSOCIATES FORM S-4, supra note 83, at 1; VERISIGN, INC., REGISTRATION STATEMENT ON FORM S-4 38 (2000) [hereinafter VERISIGN/NETWORK SOLUTIONS FORM S-4] (for Network Solutions merger). A common notion among investment bankers and business people, however, is that every mega-merger involves an acquirer and a target, despite the window dressing of the merger-of-equals. See Carey, supra note 51, at 154 ("Of course, most mergers are really acquisitions.").

${ }^{97}$ See, e.g., BP AMOCO/ARCO SCHEDULE 14A, supra note 80, at 27 ("ARCO's management and board of directors also determined that ARCO, as a smaller international oil company with relatively higher leverage than its competitors, had more limited ability to aggressively pursue new capital intensive opportunities."); id. at 31 (BP observed that the combination "will diversify its portfolio internationally, bolster or extend its strategic position in key areas, and significantly increase its options for growth").

${ }^{98}$ See AT\&T/TCI FORM S-4, supra note 82, at 8-9 (describing how part of the acquired businesses, such as Liberty Media, will be operated separately); PFIZER/WARNER-LAMBERT FORM S-4, supra note 81 , at I-40-46 (emphasizing continuity of Warner-Lambert, if only to 


\section{Extremeness Aversion}

Acting under this bias, people do not like extremes and tend to select the middle strategy or outcome when they are presented with several choices in their decision-making. In mega-merger decision-making, the decision to do a transaction would be psychologically compelling if it was seen under extremeness aversion as a balanced or middle response to the circumstances facing a firm, such as industry shocks or consolidation. One obvious path or extreme is for each firm not to do any transaction and to remain independent, responding to industry circumstances by itself. The other extreme is for each firm to engage in another merger, whether an actual alternative or a future proposal. This would leave the middle, reasonable choice as the mega-merger in question. It should be emphasized that the presence of this bias does not mean that the extremes were seriously considered in the decision-making; indeed, extremeness aversion can give the decision-maker the feeling that he or she has examined the alternatives without ever seriously considering them. ${ }^{99}$

Admittedly, law may both support and undercut the presence and strength of this bias in merger decision-making. Under the business judgment rule of corporate law, a board of directors must gather information when evaluating a transaction, and one reasonable source of information would come from a consideration of alternative strategies. ${ }^{100}$ Under both federal securities law and the state corporate law duty of disclosure, a company's board must disclose any concrete alternative strategy to the shareholders. ${ }^{101}$ The obligation to consider, and even to seek out, alternatives is required if a change of control of the firm is occurring. ${ }^{102} \mathrm{~A}$ board, however, is under no legal obligation to describe in detail

reassure the target's employees where Pfizer broke up a merger-of-equals between WamerLambert and American Home Products). The same strong characterization applies to the $\mathrm{GE} /$ Honeywell merger, where GE broke up the merger-of-equals between United Technologies and GE and, in a very curious move, the Honeywell board negotiated for the continuation of GE's famous manager Jack Welch, who was otherwise planning to retire. See GE/HONEYWELL FORM S-4, supra note 85 , at 19-21.

${ }^{99}$ See JANIS, supra note 42 , at 244.

${ }^{100}$ See, e.g., Smith v. Van Gorkom, 488 A.2d 858, 882-88 (Del. 1985) (describing how directors of a target failed to meet their duty of care, and thus do not receive "business judgment" protection, by neglecting to do a "market test" of alternative transactions).

${ }^{101}$ See In re Time Wamer Inc. Securities Litig., 9 F.3d 259, 268 (2d Cir. 1993), cert. denied, 511 U.S. 1017 (1994) ("Rather, we hold that when a corporation is pursuing a specific business goal and announces that goal as well as an intended approach for reaching it, it may come under an obligation to disclose other approaches to reaching the goal when those approaches are under active and serious consideration."); see infra Part VI.

${ }^{102}$ For the classic statement, see Paramount Communications Inc. v. QVC Network, 637 A.2d 34, 48 (Del. 1993) ("Accordingly, when a corporation undertakes a transaction which will cause: (a) a change in corporate control; or (b) a break-up of the corporate entity, the directors' obligation is to seek the best value reasonably available to the stockholders."). 
or emphasize alternatives that it has rejected and can devote most attention to promoting the transaction that it recommends. ${ }^{103}$

The information in Tables $1-4$ reflects both the presence and strength of this bias. If the bias is clearly present and the firms emphasize it, even only with respect to the choices of one merger partner (usually the target), the transaction receives a strong designation. If the bias exists in full form, with reference to extremes and the reasonable middle choice, but is not particularly emphasized, the merger has a middle designation. Finally, if a transaction makes a passing description of the merger as a choice among alternatives, it receives a weak rating. The italics in Tables 2-4 signal the merger partner or partners for which the "extremeness aversion" is particularly pronounced. Under this characterization, eleven transactions receive a strong and fourteen a middle characterization (see Table 1).

Narratives about the background to the merger, a standard section in the Form S-4 or F-4, typically highlight the extremes of "no transaction" or "other mergers." 104 The following remark, which has both a rational choice ${ }^{105}$ and an

${ }^{103}$ See infra Part VI.

${ }^{104}$ See, e.g., AOUTTME WARNER FORM S-4, supra note 92, at 37 (Time Wamer's board explains that it "had explored alternatives to the proposed combination of Time Warner and America Online, including the internal development of an Internet distribution infrastructure and growth through acquisitions.'); BELL ATLANTIC/GTE FORM S-4, supra note 93, at I-19-20 ('In the last several years, GTE's management has considered alternative strategies, including those based upon remaining independent and developing new business opportunities utilizing GTE's existing resources and assets, as well as alternatives based upon a combination with one or more telecommunications or data companies."). The DEUTSCHE TELECOM/VOICESTREAM FORM F-4 provides the following full presentation of the extremes with the middle ground as the final (reasonable) alternative:

Representatives of VoiceStream's management and VoiceStream's financial and legal advisors made presentations regarding the various strategic alternatives available to VoiceStream, including (1) continuing as an independent entity and entering into strategic financing or business arrangements with other industry participants or financing sources that would assist VoiceStream in financing its business strategy, (2) pursuing one or more significant acquisitions of other wireless telecommunications companies and (3) entering into a combination with Deutsche Telekom or the third party that had submitted the preliminary proposal on July 7,2000 , as orally modified by its financial advisors on July $19,2000$.

DEUTSCHE TELECOM/VOICESTREAM FORM F-4, supra note 82, at 58; see also ARCO/BP AMOCO SCHEDULE 14A, supra note 80, at 28 (describing how ARCO decided to find a merger partner, hired an investment banker, shopped itself around, and despite other bids from Exxon, Royal Dutch Shell, and other unnamed partners, "conclude[d] that [another merger] could not realize as great a degree of strategic fit, potential for application of best practices and level of cost savings as a combination with BP Amoco"); id. at 29 (giving the price of a competing offer).

${ }^{105}$ That is, as a general strategic matter, acquisitions and mergers are a common, rational 
extremeness aversion origin, is common here (with appropriate modification for the industry): management of both companies "have, over time, regularly considered the possibility of acquisitions and strategic combinations with a variety of financial institutions and their potential strategic fit with such institutions based on the businesses conducted thereby, their management and employee cultures and the geographic location and breadth of their businesses."106 Because so many of the mega-mergers emphasize industry consolidation, myopia tends to lead to an expression of extremeness aversion. That is, in a consolidating industry, the alternative of remaining "single" is raised, but quickly dismissed, while the possibility of combinations with other merger partners is mentioned. ${ }^{107}$ As is clear from the italics in Tables 2-4, moreover, the extremeness aversion focus is generally on the target firm. ${ }^{108}$ An equal focus on the acquirer and target may occur, however, in an industry with widespread consolidation and megamergers-of-equals. ${ }^{109}$ And some of the strongest examples of the bias arise in a mega-merger that arose from competitive bidding. In these cases, a specific alternative to the mega-merger must be described and its rejection justified. ${ }^{10}$

way of expanding a business, and any transaction must be evaluated against what can be achieved purely through a firm's internal growth.

${ }^{106}$ See, e.g., BANC ONE CORP., REGISTRATION STATEMENT ON FORM S-4 22 (1998) [hereinafter BANC ONE/FIRST CHICAGO FORM S-4] (for First Chicago merger).

${ }^{107}$ See, e.g., AT\&T/MEDIAONE FoRM S-4, supra note 96, at II-7 (MediaOne was concerned about needing a merger partner, in the reasons for the merger, it cites "current industry trends, including the likelihood of continuing consolidation and increasing competition in the cable television and broadband industries, and the corresponding decrease in the number of suitable or available merger partners for MediaOne Group"). Mobil justified its merger with Exxon by noting:

[T]he risks and potential rewards associated with, as an alternative to the merger, continuing to execute Mobil's strategic plan as an independent entity. Such risks include, among others, the risks associated with remaining independent amidst industry-wide consolidation, and such rewards include, among others, the ability of existing Mobil shareholders to partake in the potential future growth and profitability of Mobil).

EXXON/MOBL FORM S-4, supra note 83, at I-24 (emphasis added).

${ }^{108}$ There is likely to be a rational, as well as quasi-rational, justification for this, as when a long-standing and well-known firm is being subsumed in another. The disappearing firm's board feels particularly compelled to justify the change in the firm's existence, despite the board's assertion, under the status quo bias, that nothing is changing! See, e.g., NORWEST/WELLS FARGO FORM S-4, supra note 83, at 22-25 (describing Wells Fargo's decision, despite its ability to stay independent, to join with another firm).

${ }^{109}$ See DAIMLER/CHRYSLER FORM F-4, supra note 91, at 49, 58.

${ }^{110}$ See, e.g., PFIZER/WARNER-LAMBERT FORM S-4, supra note 81, at I-25-33 (discussing Warner-Lambert's proposed mega-merger-of-equals with American Home Products, the then possible bid by Proctor \& Gamble, and finally, the merger with Pfizer); QWEST/US WEST FORM S-4, supra note 81, at I-10-18 (where Qwest prevails over Global Crossing while itself pursuing other acquisitions); MCI WORLDCOM/SPRINT FORM S-4, supra note 87, at 39-45 (discussing Sprint's consideration of other merger partners). Of course, given that these 
A merger is sometimes qualified as unique, with the statement or suggestion that other transactions do not fit into this category and the alternative of not doing the merger involves unreasonably foregoing this special opportunity. ${ }^{11}$ The stated uniqueness of the transaction will occasionally push into the background an explicit description of altematives, resulting, fairly or unfairly, in a weak characterization. ${ }^{112}$

\section{Over-Optimism}

It is not surprising that the data set shows considerable presence of overoptimism, for this bias is both one of the classic explanations for value-decreasing mergers and a characteristic of healthy human beings. ${ }^{113}$ Given the statistics on the failure of most mergers, CEOs, board members, and shareholders of merging firms must indeed be "over-optimistic" to think that their transaction will succeed. ${ }^{114}$ Indeed, CEOs will acknowledge the validity of statistics about poorly performing mergers, but they will argue that their transaction is special or will assert, with little support, that the studies do not apply to their corporations. ${ }^{115}$

transactions often generate litigation from shareholders who argue that the target board did not select the best deal, the firms' lawyers write the section on the merger's background with an eye to existing or potential lawsuits.

${ }^{11}$ See, e.g., DAIMLER/CHRYSLER FORM F-4, supra note 91, at 52 ("[T] he Chrysler Board believed that a combination with Daimler-Benz represented a unique strategic opportunity for Chrysler and its stockholders, who could continue to participate as stockholders in the combined company.... Therefore, the Chrysler Board did not seek a transaction with any other company."); NATIONSBANK/BANKAMERICA FORM S-4, supra note 83, at 41 (referring to the transaction as "a unique opportunity to create a premier financial services company with a truly national banking franchise").

${ }^{112}$ There are only five such characterizations in the data set: AT\&T/TCI and Travelers/Citicorp in 1998; Dow/Union Carbide and Viacom/CBS in 1999; and Clear Channel/AMFM in 2000. See, e.g., TRAVELERS/CITICORP FORM S-4, supra note 82, at 19 ("Travelers and Citicorp have a unique opportunity to take advantage of the complementary strategic fit of their businesses, combining Citicorp's and Travelers' products to create one of the largest, most diversified financial services companies in the world, with growth opportunities not available to either company on its own."). This view led to a weak characterization for extremeness aversion in their 1998 merger. See supra Table 2.

${ }^{113}$ See ROBERT J. SHILLR, IRRATIONAL EXUBERANCE 142 (2000).

${ }^{114}$ See supra Part II.

${ }^{115}$ See Jeffrey Ball et al., Grinding Gears: For Two Car Giants, A Megamerger Isn't The Road to Riches, WALLST. J., Oct. 27, 2000, at A1 (describing how Daimler had internal studies done that showed the failure of most mega-mergers but went ahead anyway with the Chrysler merger). Dennis Carey cites the following remarks of Alex Mandl, Chairman and CEO of Teligent:

I would take issue with the idea that most mergers end up being failures. I know there are studies from the 1970s and ' 80 s that will tell you that. But when I look at many companies today - particularly new-economy companies like Cisco and WorldCom-I have a hard time dismissing the strategic power of M\&A. 
Over-optimism is pervasive in the mega-mergers, even coloring a seemingly neutral assessment of the likely growth of the two companies following the merger, because growth will happen if everything goes right (which it rarely does).

A mega-merger receives a strong characterization if over-optimism is particularly stressed and approaches the hyperbolic (11). In the middle category, the bias is clearly present, but not over-emphasized (13). For the weak category, the over-optimism, while present, is either balanced by emphasis on what might cause the transaction to fail or, in a rare case, is understated or absent (6). As with all of the psychological factors, the categorization of each mega-merger on overoptimism is a question of judgment, particularly about assigning a transaction to either the strong or middle categories.

In the "strong" characterization, parties dwell upon the synergies from and exaggerate the unique nature of the transaction. The AOL/Time Warner megamerger is exemplary in this regard because the parties projected $\$ 1$ billion in firstyear synergies and boasted that the new company "will create a preeminent global company that, for the first time, will fully integrate traditional and new media and communications businesses and technologies."116 In many of the examples, there is certainly a rational justification intertwined with the over-optimistic presentation, such as the need to convince finance professionals that a particular deal in a consolidating industry is the right one; ${ }^{117}$ to overcome the concern of

Carey, supra note 51, at 146. See Martin Lipton, Mergers: Past, Present and Future 10 (Jan. 10, 2001) (unpublished manuscript, on file with author) (famous takeover lawyer makes the following incredible statement, unsupported by and contradictory to all finance data: "Most academic studies of mergers argue that a majority of mergers are not beneficial to the acquiring company.... The overwhelming majority of negotiated strategic mergers that $I$ have been involved in over a 45-year period were successful for the acquiring company.").

${ }^{116}$ See AOLTIME WARNER FORM S-4, supra note 92, at 33-35. The Chase/JP Morgan transaction is similarly characterized:

The proposed merger will create one of the largest and most globally diversified financial services companies in the world, with approximately $\$ 660$ billion in assets and over $\$ 36$ billion in stockholders' equity, and will provide us with a unique opportunity to leverage our premier brands and comprehensive capabilities across an unparalleled client franchise. We believe that the combined company, which will be named J.P. Morgan Chase \& Co., will be a formidable competitor in financial services, positioned for superior growth and profitability in the rapidly changing financial services industry.

CHASE/J.P. MORGAN FORM S-4, supra note 79, at 1; TRAVELERS/CITICORP FORM S-4, supra note 82 , at 19 (referring to joint reasons for the merger: "Travelers and Citicorp have a unique opportunity to take advantage of the complementary strategic fit of their businesses, combining Citicorp's and Travelers' products to create one of the largest, most diversified financial services companies in the world, with growth opportunities not available to either company on its own.").

${ }^{117}$ See, e.g., MCI WORLDCOM/SPRINT FORM S-4, supra note 87, at 59-61 (describing detailed cost and capital savings, as well as revenue benefits, from merger); QWEST/US WEST FORM S-4, supra note 81, at I-17-18 (discussing how the mega-merger will allow the combined 
regulators in an industry like financial services where mega-mergers have previously been rare; ${ }^{118}$ or to convince employees and local communities that a cross-border transaction will not result in unacceptable changes to them. ${ }^{119}$ In short, the bias is also motivating the mega-merger decision-making.

In the middle category, over-optimism is expressed and the positive projections of cost savings or revenue enhancements are given without hyperbole. For example, AT\&T offered a highly optimistic view of its combination of cable with long distance in its merger with MediaOne in $1999,{ }^{120}$ Citigroup pointed to the uniqueness of its transaction with Associates First Capital, ${ }^{121}$ and Dow discussed in detail the synergies in its mega-merger with Union Carbide. ${ }^{122}$

firm to become one of the "top-tier" of the telecommunications industry and realize revenue synergies of $\$ 12$ billion); Press Release, MCI WorldCom/Sprint, MCI Worldcom and Sprint Create Pre-Eminent Global Communications Company for the 21st Century (Oct. 5, 1999), at http://www3.sprint/com/PR (Oct. 5, 1999) (stating that "merger creates the pre-eminent global communications company for the 21 st century-a dramatically more effective competitor').

${ }^{118}$ See, e.g., NATIONSBANK/BANKAMERICA FORM S-4, supra note 83, at 2 ("The merger will create the first coast-to-coast United States banking franchise, under the name 'BankAmerica Corporation.' We believe the merger will provide the combined company with unprecedented capabilities in serving individuals, businesses and corporate, institutional and govemmental clients across the nation and around the world."). Firstar and U.S. Bancorp voiced a similar sentiment:

We are creating the industry leader in growth, performance and diversification. The combined companies will have a multitude of high growth, non-banking businesses as well as an enviable banking franchise in attractive growth markets. We're already two of the most efficient banking franchises in the country, so we can quickly devote our attention to enhancing our customer relationships, integrating our businesses, and remaining the low cost provider in our key business areas. The new U.S. Bancorp will be the leader in service quality and financial performance.

Press Release, Firstar/U.S. Bancorp, Firstar and U.S. Bancorp Merge, Creating $\$ 160$ Billion High-Growth Financial Services Company (Oct. 4, 2000), at http://www.corporate-it.net/ireye/ir_site.zhtml (Oct. 4, 2000).

${ }^{199}$ See, e.g., DAIMLER/CHRYSLER FORM F-4, supra note 91, at 51 ("The opportunities for significant synergies afforded by a combination of Chrysler and Daimler-Benz-based not on plant closings or lay-offs, but on such factors as shared technologies, distribution, purchasing and know-how."). But see DEUTSCHE TELEKOM/VOICESTREAM FORM F-4, supra note 82, at 59-60 (downplaying optimism in a cross-border merger).

${ }^{120}$ See AT\&T/MEDIAONE FORM S-4, supra note 96, at 31 ("AT\&T believes the Merger will redefine the communications industry landscape.").

${ }^{121}$ See CITIGROUP/AsSOCIATES ForM S-4, supra note 83, at 19 ("The merger presents Citigroup with a unique opportunity to enhance stockholder value by taking advantage of a highly complementary strategic fit for Citigroup with a partner that will strengthen even further Citigroup's leading position in the global financial services industry.").

${ }^{122}$ See DOW/UNION CARBIDE FORM S-4, supra note 84, at 22 (explaining that the merget will achieve " $\$ 250$ million in synergies in the first year following the merger and $\$ 500$ million in symergies per year thereafter"). 
However, references to possible negative results balance the optimism. ${ }^{123}$

A mega-merger in the weak category reveals over-optimism but also highlights the risks of the transaction. ${ }^{124}$ The cautionary language has a legal origin. SEC rules require disclosure of risk factors, and firms in certain industries, such as high technology, gas, and electrical utilities, may have considerable risks that need to be revealed and emphasized. ${ }^{125}$ Moreover, if federal securities law requires disclosure in an SEC document to include language cautioning the reader that the forward-looking statements may not be realized, the language will generally protect those responsible for the preparation of the document from liability under such law. ${ }^{126}$ This law and SEC rules thus encourage lawyers involved in drafting the documents to play down or balance the over-optimism.

However, a valid question is whether the discussion of risk factors or the cautionary language actually balances the over-optimism. While the warnings may be legally adequate, they are designed to provide additional information, not to negate the over-optimism. SEC disclosure documents do not speculate about and quantify what would happen if the transaction does not work out-actions that might have some force in negating the over- optimism. ${ }^{127}$ Although a reader might figure out that the merger projections might not be realized if the transaction fails, he or she would find it difficult to deduce from a typical Form S4 other potential negative consequences of the transaction, such as costs incurred in attempting to combine the firms' operations or the loss of the new firm's business because of competitors taking advantage of its disarray. A categorization of a merger as "middle" and "weak" on over-optimism might thus underestimate

${ }^{123} I d$. at 14 (quantifying costs and expenses resulting from the merger, with estimates of $\$ 75$ million of transaction costs and one-time costs of $\$ 200-400$ million, and then offering the following overarching qualification: "There can be no assurance that the combined company will not incur additional charges to reflect costs associated with the merger.").

${ }^{124}$ See, e.g., EL PASO/COASTAL FORM S-4, supra note 85, at 5 ("We believe that by combining the highly complementary assets and operations of El Paso and Coastal, we will create a company that will be the leading integrated natural gas and power company in North America and will have tremendous opportunities for growth and creation of stockholder value."); id. at 19-25 (including six pages discussing risks and mentioning reasons why the merger could fail); CLEAR CHANNEL/AMFM FORM S-4, supra note 84, at I-18-24 (explaining that the combined company will have significant debt and describing the other problems with. the merger). The GE/Honeywell merger displays a very understated optimism. See GE/HONEYWELL FORM S-4, supra note 85. Could the renowned master CEO and acquirer, Jack Welch, know something about how to achieve a successful merger (i.e., don't promise too much) even if he had later to abandon the transaction because of antitrust problems?

${ }^{125}$ See Form S-4, supra note 58, at Item 3 (cross-referencing to 17 C.F.R. $\$ 229.503$ (c) (2001)) ("Where appropriate, provide under the caption 'Risk Factors' a discussion of the most significant factors that make the offering speculative or risky.").

${ }^{126}$ See 15 U.S.C. \$ 77z-2 (1994).

${ }^{127}$ See Kuran \& Sunstein, supra note 44, at 721 ("The point is critical, for people display much less eagerness to obtain particular benefits when they gain awareness of the corresponding costs."). 
the presence of this bias in mega-mergers.

\section{Anchoring Heuristic}

Under this heuristic, or shortcut way of decision-making, people decide on the basis of a value or "anchor" that may be arbitrarily chosen, often because it is "available" or strongly present to the mind. People then hold fast to this anchor, despite the presence of rational values. Evidence of other psychological factors, such as myopia or loss aversion, also supports this heuristic. For example, in a particular industry a specific mega-merger is the immediate justification for a firm's own mega-merger and the transaction against which all other similar deals are measured. For Tables 1-4, however, the characterization of the anchoring heuristic uses other, more limited evidence, the most common being the price from comparable transactions. A strong rating is given to mergers that include the price reference as well as some other value to which the transaction is anchored (13). The middle category contains mergers that generally focus only on the price value (16), and the weak group (1) finds little or no value anchoring.

The reliance of both firms upon prices paid in comparable transactions is generally based upon the fairness opinions of investment bankers that provide such data and in which they opine on the faimess of the merger price to their client firm. There are, of course, rational reasons for this reliance. As a legal matter, a company's board puts itself into a better legal position by using an investment banker that reviews the transaction and its price in comparison to similar transactions. ${ }^{128}$ Moreover, it would be irrational, absent a serious change in market circumstances, not to rely upon recent deal prices, which appear to reflect investors' current attitudes towards and valuations of similar combinations. ${ }^{129}$ Mobil's statement in its reasons for the merger with Exxon that "the value of the exchange ratio... relative to the stock price premiums paid in mergers of comparable size ... that the premium offered in the merger was within the range of premiums paid in comparable transactions" is thus typical. ${ }^{130}$ Indeed, so common is this reliance upon values in comparable transactions that it is unusual when the firms do not provide them. ${ }^{131}$ Again, the assignment of a megamerger to the strong as opposed to the middle category depends upon other examples of anchoring, such as the reliance (chiefly, but not exclusively, by the

${ }^{128}$ See Smith v. Van Gorkom, 488 A.2d 858, 882-88 (Del. 1985).

${ }^{129}$ As a cognitive matter, it is likely that both merging firms and their bankers depend upon socially constructed models of what they consider to be comparable firms. Accordingly, prices paid in transactions involving these firms become the "anchor" against which they measure their own deal. See Porac \& Thomas, supra note 78, at 237.

${ }^{130}$ See EXXON/MOBL FORM S-4, supra note 83, at I-24.

${ }^{131}$ Travelers/Citicorp is the one example in the data, for there were no faimess opinions given. However, both firms had internal investment banking operations that could have provided information on comparable transactions to their boards. 
target) on the previous merger or acquisition success of one or both firms as a justification for the merger ${ }^{132}$ or the highlighting of the "standard" nature of the features of the transaction. ${ }^{133}$

\section{Availability Heuristic, Framing Effects, and Hindsight Bias}

Tables 1-4 make no reference to other psychological factors, such as the use of the availability heuristic, framing effects, and hindsight bias. One concern here was to avoid duplicate presentations of data, a concern mentioned under "anchoring" above. The availability heuristic, for example, posits that people act upon, and attribute importance to, events or values present to their minds. Signs in the data showing the presence of this heuristic would also reveal myopia, loss aversion, and anchoring. For the same reason, no separate listing for framing effects is provided. Examples of its use appear under loss aversion and extremeness aversion, which are triggered by how the decision is "framed" or presented. Hindsight bias is simply absent from the data. Because the bias

${ }^{132}$ See, e.g., AOL/TME WARNER FORM S-4, supra note 92, at 33. AOL's merger with Time Warner was justified as follows:

The [AOL] board of directors also took note of the fact that the merger is with a long-time business partner of America Online with a proven history of successful collaborations, including cross-promotion and marketing activities between the two companies. Both companies also have management teams with demonstrated ability to manage the integration process of major business combinations.

Id.; Press Release, Firstar/U.S. Bancorp, supra note 118 (with Firstar emphasizing that it has been good at integrating companies in the past: "In each previous merger integration, we've achieved our operating goals on time and on budget."); see also BANC ONE/FIRST CHCAGO FORM S-4, supra note 106, at 26 (Banc One took into account "the fact that the managements of both Banc One and FCN had demonstrated the ability to successfully integrate substantial acquisitions in a timely manner."); EL PASO/COASTAL FORM S-4, supra note 85, at 28 ("Based on El Paso's experience in its past business combinations, including its merger with Sonat Inc. and its acquisition of Tenneco Inc.'s energy business, we believe the combined company may achieve annual cost savings in excess of \$200 million."); SBC/AMERITECH FORM S-4, supra note 79, at 24 ('In addition, the Ameritech Board considered the demonstrated ability of SBC's management to successfully integrate and obtain synergistic benefits from previous SBC acquisitions, most notably SBC's acquisition of Pacific Telesis Group.").

${ }^{133}$ See, e.g., BP/AMOCO SCHEDULE 14A, supra note 83, at 29 (rationalizing their deal protection devices in this way: "This [Stock Option Agreement] and the termination fees contemplated by the Merger Agreement evidenced the parties' commitment to the business combination between them and the parties believed that they were customary features of transactions of this nature involving United States companies."); CLEAR CHANNEL/AMFM FORM S-4, supra note 84 , at I-29 (in the AMFM board meeting, counsel explains to the board that "the amount of the termination fees in the merger agreement were appropriate under Delaware law based on advice of Delaware legal counsel, which based its advice on its review and knowledge of the level of termination fees associated with similar Delaware transactions in regulated industries that had been held enforceable"). 
involves re-predicting a past event from a present standpoint (i.e., coming to believe that a past outcome was more predictable than in fact it was), it is unlikely to play a role in a present merger decision about the future of two firms. ${ }^{134}$

\section{Value Destruction in the Mega-Mergers}

One assumption of the article is that there is likely to be a causal relation between the exercise of the psychological factors in mega-merger decisionmaking and the value destruction for shareholders that so frequently results from the transactions. If mergers were generally successes, it would not be worth examining the factors, except as a way of improving decision-making at the margin. Available systematic, rather than anecdotal, ${ }^{135}$ data on the mega-mergers in this study establish that they too follow the expected pattern of value destruction for shareholders. Although a full account on their success or failure from the shareholder value perspective has to await future work by financial economists, studies of past transactions indicate that a merger's bad outcome generally worsens the longer the time period from the decision date that an analyst uses to measure its financial results. ${ }^{136}$

A survey of mega-mergers by The Wall Street Journal, completed on October 27, 2000, covering many of the same transactions as are in this article's data set, provides evidence of their value destruction. ${ }^{137}$ The writers compared the price of the acquirer's stock on the day prior to the announcement of the transaction with the price on October 27, 2000, and computed its percentage increase/decrease. They then computed the percentage change, for the same period, for (1) the Standard \& Poor's 500 Index and (2) an appropriate industry index for a merger. Of the eighteen transactions that were in both of our data sets, thirteen had under-performed the S\&P 500 Index and twelve had underperformed the applicable industry index. ${ }^{138}$

To tailor a valuation study to this article's data set, I conducted an analysis similar to the one performed by The Wall Street Journal reporters. In the analysis, I computed the percentage change in the value of the acquirer's shares from the

${ }^{134}$ I owe this clarification to Professor Jeffrey Rachlinski.

${ }^{135}$ For some of the anecdotal data, see Fanto, supra note 10, at 272-74.

${ }^{136}$ See id. at 256-57.

${ }^{137}$ Steven Lipin \& Nikhil Deogun, Big Mergers of '90s Prove Disappointing to Shareholders, WALL ST. J., Oct. 30, 2000, at C21. I am grateful to Professor Jeffrey Gordon of Columbia University School of Law for giving me a copy of the spreadsheet used to prepare the article, which he obtained from its authors.

${ }^{138}$ Completed M\&A Deals Involving U.S. Targets and Greater Than $\$ 15$ Billion1/1/97-10/27/2000 (2001) (unpublished manuscript, on file with author). The differences between the data set in The Wall Street Journal article and that in this article appear to arise from the use by The Wall Street Journal authors of cash, as well as stock, transactions and their selection of the largest transactions over 1998-2000, as opposed to the ten largest in each year during that period. 
closing price on the last trading day before announcement of the merger, as reported in the acquirer's Form S-4, Form F-4, or Schedule 14A, to a recent closing price. ${ }^{139}$ As in the case of The Wall Street Journal study, I adjusted the pre-merger stock price for any subsequent stock splits. ${ }^{140} \mathrm{I}$ then compared this percentage change with the percentage change over the same period for a Dow Jones industry index appropriate for the acquirer in a given merger. ${ }^{141}$ Because in my view this industry-specific comparison would better reflect the relative performance of an acquirer's stock, I did not compare this performance to the results of a general, diversified stock index, as The Wall Street Journal reporters had done.

Tables 5-7 provide the results of this analysis, indicating the positive or negative performance of an acquirer's stock in relation to the industry index. Table 5 provides the kind of results that, from a conservative perspective on the basis of data from past transactions, one would expect from the mega-mergers in the study: at least half of the transactions have lost value in comparison to a transaction's index. Admittedly, two cases, both involving oil companies, are close calls. At best, these transactions are neutral, leaving again half of the transactions as failures with respect to stock price performance if the 1998 data set is reduced to eight mergers. Some of the failures have been well publicized (AT\&T/TCI, Banc One/First Chicago, Daimler/Chrysler, NationsBank/Bank America) and may reach catastrophic proportions. ${ }^{142}$ The successes are concentrated in "Baby Bell" telecommunications companies and in financial and oil company mergers. ${ }^{143}$

${ }^{139}$ The closing price used was that reported in INTERACTIVE WALL ST. J., Feb. 20, 2001, at http://www.wsj.com (last visited Aug. 19, 2001).

${ }^{140}$ For example, if, subsequent to the pre-merger date, the acquirer's stock split with two shares issued for every existing share, its current stock price would need to be compared to an adjusted, comparable pre-merger stock price (i.e., the pre-merger stock price would have to be divided by two). See id.

${ }^{141}$ The industry index used was a Dow Jones industry index provided in the stock chart of each acquirer in The Interactive Wall Street Journal, supra note 139, which supplies an appropriate industry index for each stock. I had to approximate each index's value on the premerger date from a chart providing the index's value over the relevant period. This approximation was adequate for the goal of this exercise: to obtain a rough sense of the comparative performance of an acquirer following a mega-merger. See INTERACTIVE WALL ST. J., supra note 139.

${ }^{142}$ See, e.g., Diana B. Henriques, Bank of America to Cut Up to $6.7 \%$ of Work Force, or 10,000 Jobs, N.Y. TIMES, July 29, 2000, at Cl; Amy Merrick, Bank One Will Trim Size of Board, WAll ST. J., Aug. 23, 2000, at Cl; Ma Bell Does the Splits, ECONOMIST, Oct. 28, 2000, at 57; Brock Yates, Daimler Drives Chrysler into a Ditch, WALL ST. J., Nov. 8, 2000, at A26.

${ }^{143}$ See, e.g., Shawn Young, As Their Onetime Parent Falters, Four Bells Flourish, WaLl ST. J., Oct. 26, 2000, at B1. 
Table 6 shows worse results for the 1999 transactions, with seven out of ten losing value. Again, if the somewhat close cases of Viacom/CBS and AT\&T/MediaOne are eliminated, the general outcome still stands-five out of eight lose value. The failures here are not concentrated in any specific industry, but are spread among the industries in which these large transactions occurred in 1999: broadcasting, insurance, oil, and telecommunications. ${ }^{144}$

Table 7 shows results similar to Tables 5 and 6 . Seven out of ten transactions destroyed shareholder value, with one being neutral. Again, there are some close questions regarding transactions like Chevron/Texaco and the abandoned GE/Honeywell merger, but their elimination would actually worsen the overall results (i.e., six out of eight transactions would be negative). Even a firm such as Citigroup that managed not to destroy value in its previous merger (Travelers/Citicorp in 1998) has fallen into the negative after its mega-merger with Associates.

${ }^{144}$ See, e.g., Catherine Amst et al., Lucent: Clean Break, Clean Slate?, Bus. WK., Nov. 6, 2000, at 176; Amy Barrett, Pfizer: How Big Is Too Big?, BuS. WK., Aug. 28, 2000, at 216. 


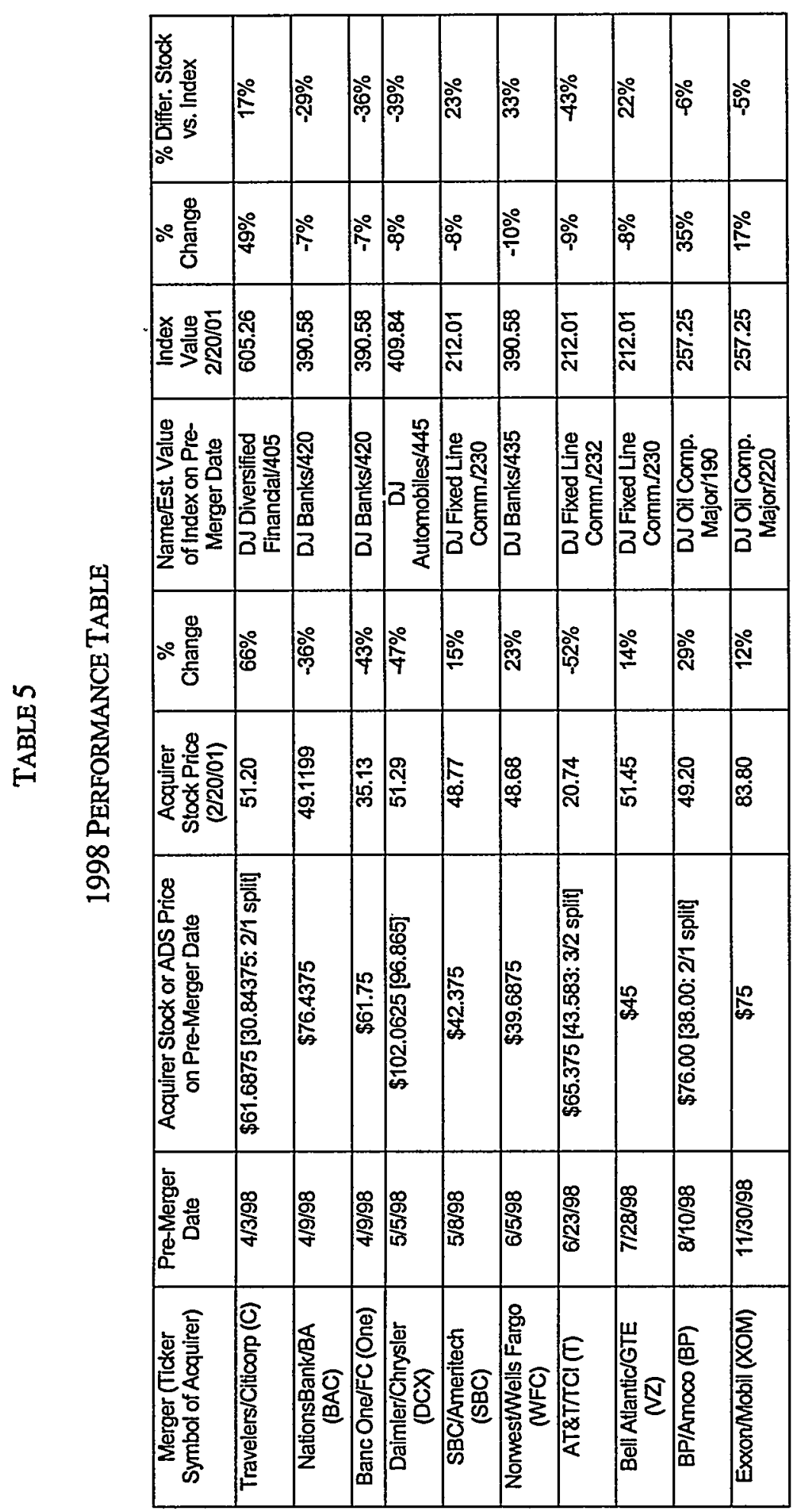




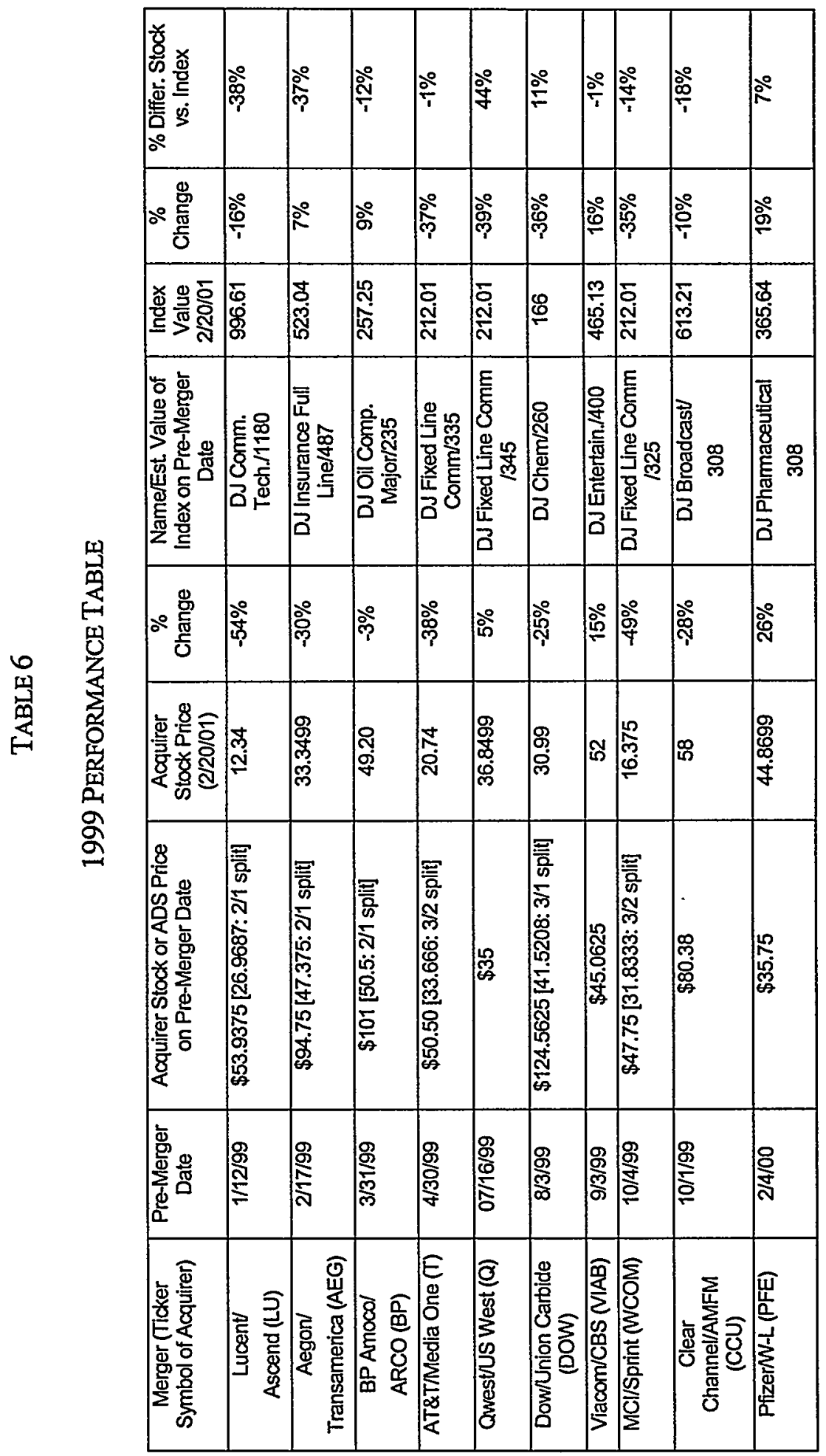




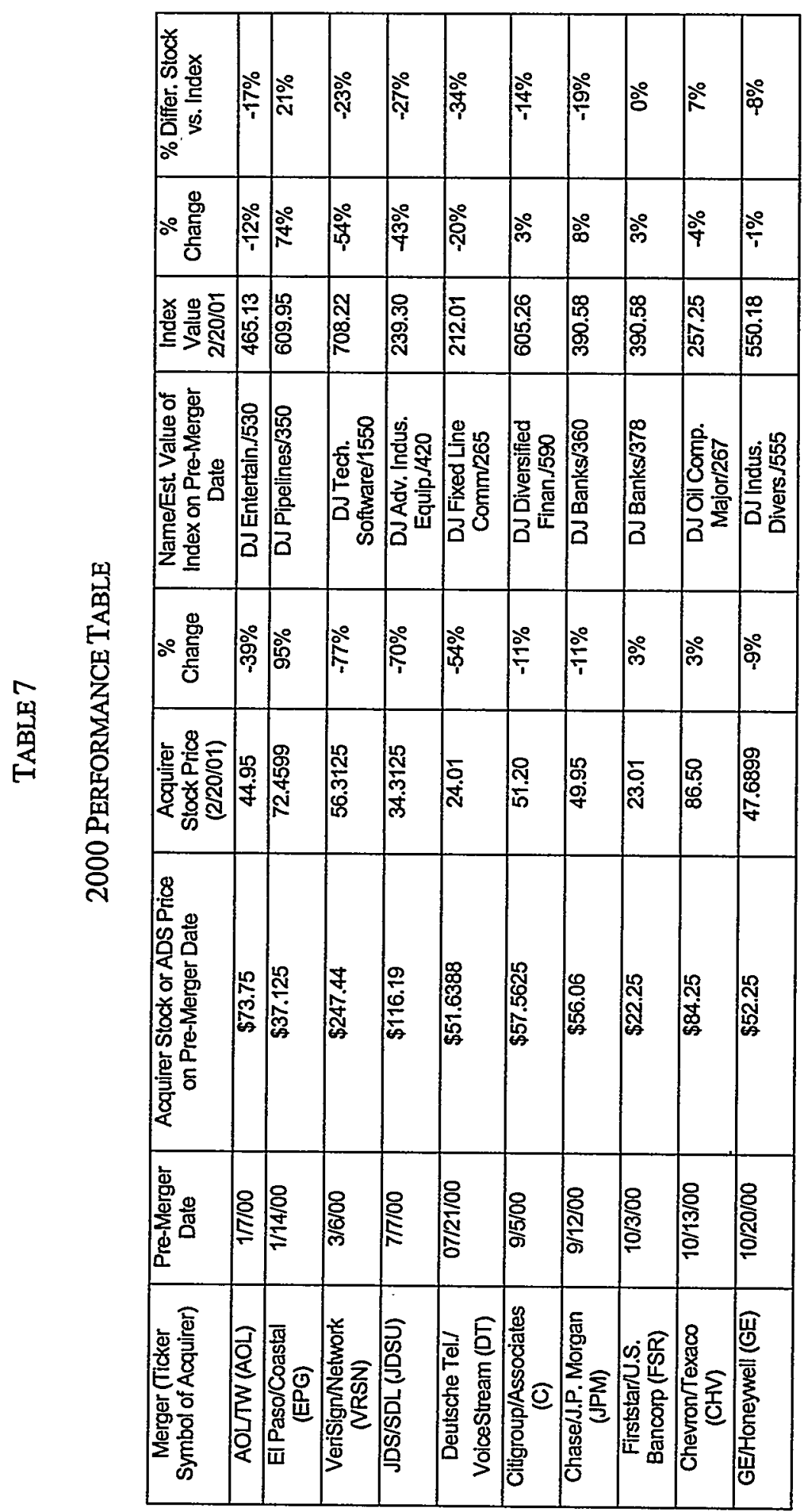


The above stock performance data is by no means conclusive as to the value destruction of the mega-mergers in the data set. No doubt financial economists will study these mega-mergers within a larger group of transactions, measure the performance of each merger over the same benchmark period and against several indices, and perform the other verifications that their discipline prescribes in order to, for instance, control for other variables in the results. Nevertheless, the above performance tables, when coupled with studies of past mergers, anecdotal evidence about the transactions, and reviews of recent merger performance, such as The Wall Street Journal's, are highly indicative of the shareholder value destruction resulting from many of these deals.

\section{Linking the Psychological Factors to Value Destruction}

It is important to look for correlations between the psychological factors in the merger data set and the share price performance of the firms. With this empirical data, one could point to potential psychological causes for good or poor merger decision-making and could propose appropriate policy to deter the former and encourage the latter. The data from the study in this article, however, does not generally establish these correlations. If, using a rough effort to establish correlations, one were to assign a number to the strength of a given psychological factor (for example, a 3 for "strong," 2 for "middle," and 1 for "weak") and compute a psychological factor average in each year for the positive- and negative-value transactions, the computation does not indicate that negative-value transactions reveal a greater presence and strength of psychological factors than do positive-value deals. Aside from 1998, where the averages are almost identical, in the other two years there is a higher "psychological" average for positive-value transactions. ${ }^{145}$ In 1998 and 1999, moreover, transactions with the highest presence and strength of the psychological factors are equally positiveand negative-value ones. A comparative glance at Tables 1-7 supports this conclusion about a lack of general correlation.

This result does not mean that there is no causal relation between the psychological factors and good or poor merger decision-making. The continuation of value-destroying mergers would intuitively suggest the opposite. ${ }^{146}$ Rather, more data on the decision-making is needed; the available

${ }^{145}$ That is, using a " $3,2,1$ " scale for "strong," "middle," and "weak," respectively, the 1998 averages are 13.75 for positive-value and 13.67 for negative-value transactions; 1999 averages are 14.33 for positive and 11.43 for negative; and the 2000 averages are 14.5 for positive and 12.43 for negative. Tables $1-4$ (for the psychological factors) were prepared before Tables 5-7 (for shareholder value), which gives some objectivity to the computation. Again, the above computation is rough. For example, the positive transactions in 1999 and 2000 are so few that the "psychological average" for them is not very meaningful.

${ }^{146}$ Of course, value-destroying mergers also likely owe much to rational, as opposed to quasi-rational, causes (e.g., decision-makers make a rational choice that turns out simply to be 
psychological data from this study requires further refinement and analysis so that the causation can be established or disproved; and all the data needs to be subjected (where possible and appropriate) to statistical analysis. For example, the loss aversion category may be too general because it sweeps in related, but slightly different, psychological motivations--"let's not change" (the status quo bias) versus "let's change to keep our position and prevent loss" (the loss aversion bias)-and one or the other motivation might be better correlated to good or poor decision-making. Moreover, some psychological factors that are present in merger decision-making and that lead to negative-value transactions may be dampened in the article's data, as, for instance, where concern about legal liability results in the highlighting of transaction risks and the downplaying of overoptimism.

There are also intriguing indications in the article's data across the three years that suggest some correlation and potentially a causal connection between the psychological factors and the outcome of merger decision-making. More negative-value transactions exhibit a strong myopia than do positive-value transactions ( 9 to 6). The same results hold true for strong loss aversion (16 to 8), strong extremeness aversion (6 to 5), strong over-optimism (6 to 4 ), and strong anchoring ( 7 to 5). These indications suggest that more analysis of the data might prove useful. Furthermore, the absence of any correlation or causal connection at this stage does not undercut the important empirical results of the article, which establish the presence and strength of the different kinds of psychological factors in mega-merger decision-making, at least with respect to those in the data set, and which thus at the very least help explain the psychological attractiveness and momentum of these transactions.

\section{LEGAL COMMENTARY}

\section{A. The Law's Response to the Psychological Factors}

Because the empirical results of the article show considerable presence and strength of psychological factors or quasi-rationality in mega-merger decisionmaking, it is important to ask how state corporate ${ }^{147}$ and federal securities laws deal with and accommodate this phenomenon. The simple answer is that, in applying the law, courts ignore the complexity of psychological reality by accepting a psychologically simplistic view of decision-making. Courts assume,

wrong).

${ }^{147}$ The focus is on Delaware corporate law, the most widely used jurisdiction of incorporation of the major public companies that are of the kind involved in mega-mergers, although the reason for Delaware law's popularity is in dispute. See, e.g., ROBERT DAINES, DOes Delaware Law IMPROVE FirM Value? 14 (Columbia L. Sch. Center for Studies in L. and Econ., Working Paper No. 159, 2000) at http://papers.ssm.com (Feb. 29, 2000) (arguing that empirical evidence suggests that Delaware corporate law does improve value). 
particularly in mergers, that behavior is instrumentally rational. ${ }^{148}$ Their assumption is that CEOs and board members generally act rationally for the good of the firm and the shareholders, and shareholders themselves act rationally for their self-interest in deciding whether to vote for a merger. ${ }^{149}$ Indeed, Vice Chancellor Strine echoed this judicial perspective when he explained why a claim for corporate waste (i.e., that board members made a wasteful decision affecting the corporation) should not survive an informed shareholder vote: "As a result, it is difficult to imagine how elimination of the waste vestige will permit the accomplishment of unconscionable corporate transactions, unless one presumes that stockholders are, as a class, irrational and that they will rubber stamp outrageous transactions contrary to their own economic interests."

Under corporate law and equity jurisprudence, moreover, courts give considerable deference to this presumed rationality of board decisions and intrude upon them only where these corporate agents might be rationally tempted to follow their own self-interest, typically defined in narrow terms pertaining to financial gain, at the expense of either the corporation or the shareholders ${ }^{151}$ or

${ }^{148}$ This view prevails regardless of whether one understands the law to establish rules or set flexible "norms." See Edward B. Rock, Saints and Sinners: How Does Delaware Corporate Law Work?, 44 UCLA L. REv. 1009, 1106 (1997) (arguing that, in their corporate law decisions, Delaware courts do not establish hard and fast rules of behavior for boards of directors, but cultivate general "norms" that set good and bad roles for parties to fill or avoid). Professor Rock presumes that this court-promoted normative behavior is straightforwardly rational. Id. at 1017.

${ }^{149}$ The importance of the shareholder vote is further based on the judicial assumption that shareholders have the right to dispose of their property as they see fit. See, e.g., In re Gaylord Container Corp. Shareholders Litig., 747 A.2d 71, 78 (Del. Ch. 1999) ("In a capitalist nation like ours, I would think it inarguable that an owner of stock has the right to sell her property, free and clear of unreasonable restrictions imposed by the directors of the corporation she partly owns.").

${ }^{150}$ See Harbor Finance Partners v. Huizenga, 751 A.2d 879, 899 (Del. Ch. 1999); see also In re IXC Communications Inc. Shareholders Litig., No. 17324, 1999 Del. Ch. LEXIS 210, at *19 (Del. Ch. 1999) (explaining why, when making a merger decision, board members who were large shareholders could not have been focused on the possibility of a later court evaluation of that merger decision, as opposed to how much they would gain from the transaction, the court writes:

I simply cannot accept a scenario that suggests that such a twisted self-interest could even exist; namely, so intense a desire to avoid an artifice of perceived legal duties (duties which in actuality this Court determines from the context, after the fact) that the directors would actively shirk their fiduciary obligations and in the process ignore their own economic self-interests.).

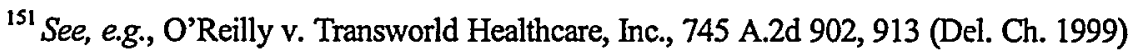
(allowing complaint to go forward with duty of loyalty claims where directors of target received cash compensation in the merger or would have been penalized financially had the merger not gone forward). On the restrictive definition of what constitutes a fiduciary's self-interest, see Crescent v. Tumer, No. 17455, 2000 Del. Ch. LEXIS 145, at *40*41 (Sept. 29, 2000) 
where there is a rare showing of the irrational. ${ }^{152}$ Even the classic "intermediate"

("Second, plaintiffs assert that Turner dominated and controlled Hunt. In support, they allege that Turner controls Hunt because of their long-standing, fifteen-year professional and personal relationship. This allegation alone fails to raise a reasonable doubt that Hunt could not exercise his independent business judgment in approving the transaction."); Solomon v. Armstrong, 747 A.2d 1098, 1117-18 (Del. Ch. 1999) (holding that self-interest is not legally present where directors owned one class of stock, as opposed to another). When courts do intervene in board decision-making because of concem that the corporate fiduciary's actions were motivated by self-interest, however, they can be searching and critical in their analysis of a fiduciary's behavior. See, e.g., Bomarko, Inc. v. International Telecharge, Inc., No. 13052, 1999 Del. Ch. LEXIS 211 (Nov. 4, 1999) (court strongly condemns controlling shareholder who engineers freeze-out merger in a deceptive way). Courts sometimes intervene when directors follow their or others' interests for reasons that are not necessarily rational, but perhaps indirectly selfinterested. See, e.g., Harbor Finance Partners, 751 A.2d at 889 ("Close familial relationships between directors can create a reasonable doubt as to impartiality.").

${ }^{152}$ This intervention often appears when there is a hard-to-establish waste claim. See, e.g., Brehm v. Eisner, 746 A.2d 244, 263 (Del. 2000) ("To be sure, there are outer limits, but they are confined to unconscionable cases where directors irrationally squander or give away corporate assets."); Cede \& Co. v. Technicolor, Inc., 634 A.2d 345, 361 (Del. 1993) (citing Sinclair Oil Corp. v. Levien, 280 A.2d 717, 720 (Del. 1971)); Ash v. McCall, No. 17132, 2000 Del. Ch. LEXIS 144, at *28 (Del. Ch. 2000) ("Moreover, it is simply illogical to presume that McKesson directors would knowingly cause McKesson to acquire a company with significant, undisclosed earnings misstatements."); Leung v. Schuler, No. 17089, 2000 Del. Ch. LEXIS 134 , at *14 (Sept. 29, 2000) ("If, however, there is any substantial good faith judgment that in the circumstances the transaction is worthwhile, there should be no finding of waste, even if the fact finder would conclude ex post that the transaction was unreasonably risky.") (emphasis added); Harbor Finance Partners, 751 A.2d at 893 ("Rather, the fundamental basis for a waste claim must rest on the pleading of facts that show that the economics of the transaction were so flawed that no disinterested person of right mind and ordinary business judgment could think the transaction beneficial to the corporation.') (emphasis added). But see Parnes v. Bally Entertainment, 722 A.2d 1243, 1246-47 (Del. 1999) (finding a complaint about the behavior of a target's CEO and his fellow directors in a merger, where CEO demanded a huge sum for the transaction to proceed, to state a claim for violation of the business judgment rule); Crescent, 2000 Del. Ch. LEXIS 145, at *45 (explaining how board members' lack of good faith implicated duty of loyalty, the court writes:

In other words, it does not matter here that the Complaint fails to establish that Sweezey and Hunt were either interested directors or that they lacked the ability to form an independent judgment. Their approval of Turner's alleged self-interested "side-deals" allegedly taint the entire merger process and strips the board of the protection of the business judgment rule. Even though the remaining directors failed to benefit personally from the merger, their judgments were aligned with that of Turner and not that of Holdings or its minority stockholders.);

Hills Stores Co. v. Bozic, 769 A.2d 88, 109 (Del. Ch. 2000) (noting that courts would intervene where a board acted with spite, but presuming that here board members were loyal to managers who worked with company during its hard times following bankruptcy, the court writes:

Notably, this is not a situation where the plaintiffs have produced evidence that the board, realizing it was going to be thrown out of office, triggered the Severance out of spite or 
standard of Unocal v. Mesa Petroleum, where the court scrutinizes the reasons for a board's defensive actions towards an unwanted bid, is triggered only by a judicial concern that board members may be focusing more on maintaining their board positions than on shareholder interests in a takeover situation. ${ }^{153}$

For the courts, a touchstone of the presumed board rationality is its orderly gathering and processing of information, ${ }^{154}$ which includes the board's reliance upon experts' preparation and "digesting" of the information for the board. ${ }^{155}$ Similarly with respect to a shareholder vote, courts hold that board members have a duty of disclosure. Under this duty, they must give shareholders all material information regarding a matter to be voted upon, such as a merger, that a rational person would consider important. ${ }^{156}$ Courts assume that a shareholder will be

hard feelings. Evidence that would support a finding that board members were sore losers and took action out of a bad faith desire to exact revenge on the stockholders for voting the wrong way would justify a trial to determine whether the board had violated its duty of loyalty.);

Sander v. Wang, No. 16640, slip op. at 25-26 (Del. Ch. Nov. 8, 1999) (allowing claim to proceed that directors violated their fiduciary duty in granting more shares under an executive stock option plan than what the plan literally allowed).

${ }^{153}$ See Unitrin, Inc. v. American General Corp., 651 A.2d 1361, 1373 (Del. 1995); Unocal Corp. v. Mesa Petroleum, 493 A.2d 946, 954-55 (Del. 1985); In re Gaylord Container Shareholders Litig., 753 A.2d 462, 475 (Del. Ch. 2000).

${ }^{154}$ See Smith v. Van Gorkom, 488 A.2d 858, 872 (Del. 1985); see also Brehm, 746 A.2d at 259. The Brehm court, in setting the standard for excuse of demand when a duty of care violation is alleged, explains:

Presuit demand will be excused in a derivative suit only if the Court of Chancery in the first instance, and this Court in its de novo review, conclude that the particularized facts in the complaint create a reasonable doubt that the informational component of the directors' decision-making process, measured by concepts of gross negligence, included consideration of all material information reasonably available.

Id.; see also id. at 262 (reliance on expert reports); Gaylord, 753 A.2d at 479 ("Furthermore, the Gaylord board engaged in a rational deliberative process to define the threat it faced, meeting on two occasions and receiving detailed legal advice from a distinguished outside law firm."). The corporate law bar assumes that this information-processing approach is the correct one to address most problems affecting boards. See, e.g., Gregory V. Varallo \& Srinivas M. Raju, $A$ Process Based Model for Analyzing Deal Protection Measures, 55 Bus. LAW. 1609, 1635-47 (2000) (arguing that the use of deal protection measures in merger contracts should be analyzed by the courts on the basis of whether the board followed the correct process in negotiating them). Yet cognition scholars consider this model of human information processing to be flawed. See Walsh, supra note 43, at 307.

${ }^{155}$ See, e.g., Ash, 2000 Del. Ch. LEXIS 144, at *30 ("What would plaintiffs have the McKesson board do in the course of making an acquisition other than hire a national accounting firm and investment bank to examine the books and records of the target company?").

${ }^{156}$ Courts call such information "material information." See Skeen v. Jo-Ann Stores, Inc., 750 A.2d 1170, 1172 (Del. 2000) (citing Louden v. Archer Daniels Midland Co., 700 A.2d 135, 142 (Del. 1997)); Zim v. VLI Corp., 681 A.2d 1050, 1056 (Del. 1996); Rosenblatt v. Getty Oil Company, 493 A.2d 929, 944 (Del. 1985) (citing TSC Industries, Inc. v. Northway, Inc., 426 
undistracted, will generally pay attention to the information given and weigh all of it equally, will ignore, or discount, any exaggeration or "puffing," and will generally be able to separate the facts from any such rhetorical embellishment. ${ }^{157}$ In one of their few psychological insights regarding shareholder decision-making, courts acknowledge that shareholders cannot absorb all information and that, as a result, they should not be inundated with unimportant details that would deflect them from consideration of key facts. ${ }^{158}$ Indeed, if shareholders are fully informed and then approve a merger, this ratification extinguishes any claim of, at a minimum, a breach of the duty of care on the board's part for self-interested behavior. It also transforms any duty of loyalty claim about board behavior, absent the presence of a controlling shareholder, to one evaluated by courts under the deferential business judgment rule. ${ }^{159}$ Moreover, shareholders' access to abundant information about firms has persuaded courts that they are on the right track in restricting their analysis of shareholder decision-making to this information processing. ${ }^{160}$

U.S. 438 (1976) (adopting the TSC standard of materiality established under federal securities law); Turner v. Berstein, No. 16190, 2000 Del. Ch. LEXIS 96, at *32 (June 6, 2000) (finding that "the defendant directors defaulted on this obligation [to disclose material facts in a merger] and did not even attempt to put together a disclosure containing any cogent recitation of the material facts pertinent to the stockholders' choice").

${ }^{157}$ See In re Newell-Rubbermaid, No. 99-C-6853, 2000 U.S. Dist. LEXIS 15190, at *19*20 (N.D. IIl. Oct. 4, 2000). Yet when courts suggest an underlying rationale for the shareholder vote, they not only couch it in terms of economic and political freedom, but also discuss its psychological implications! See, e.g., In re G.M. Class H Shareholders Litig., 734 A.2d 611, 621 (Del. Ch. 1999) (justifying a decision that upholds the freedom of shareholders to choose whether to exchange their shares for other consideration, the court says: "But mature societies like ours recognize that freedom's psychic costs are far outweighed by its emotional, spiritual, communal, and economic benefits.").

${ }^{158}$ See, e.g., TSC Industries, Inc., 426 U.S. at 448. The Court states:

Some information is of such dubious significance that insistence on its disclosure may accomplish more harm than good. The potential liability for a Rule 14a-9 violation can be great indeed, and if the standard of materiality is unnecessarily low, not only may the corporation and its management be subjected to liability for insignificant omissions or misstatements, but also management's fear of exposing itself to substantial liability may cause it simply to bury the shareholders in an avalanche of trivial information-a result that is hardly conducive to informed decisionmaking.

Id:; Solomon v. Armstrong, 747 A.2d 1098, 1130 (Del. Ch. 1999). Under federal securities laws, as interpreted by courts, disclosure is generally limited to "material" information, a term of art that is designed to eliminate from shareholder consideration (and thus to avoid shareholder distraction regarding) insignificant information.

${ }^{159}$ See, e.g., In re Lukens, Inc. Shareholders Litig., 757 A.2d 720, 736-37 (Del. Ch. 1999); Harbor Finance Partners v. Huizenga, 751 A.2d 879, 900 (Del. Ch. 1999); Solomon, 747 A.2d at 1113-17; In re Wheelabrator, Inc. Shareholders Litig., 663 A.2d 1194, 1203 (Del. Ch. 1995).

${ }^{160}$ See Harbor Finance Partners, 751 A.2d at 901 . The Delaware Chancery Court explains: 
This article's empirical evidence of the psychological factors in merger decision-making of boards, and potentially of shareholders, underscores that the judicial view of rational decision-making is overly simplistic and does not accurately reflect reality. This conclusion suggests that courts are basing their analysis of disputes arising from merger decision-making on a one-sided, incomplete, and inaccurate account of the process. Because courts are erecting the law upon this defective foundation, the capability of their jurisprudence to address adequately any problems arising in this kind of decision-making is seriously called into question. A more accurate account of the role of quasi-rationality in the process would appear to require a sustained review of, and potentially a substantial revision to, corporate and securities law on the regulation of merger decision-making.

Yet instead of undertaking this review, many legal scholars applying psychological insights to the law have looked for ways of justifying, on psychological grounds, the current deferential judicial review of business decision-making. One justification involves the argument that, in a common sense way, courts have taken the psychological factors into consideration in fashioning the law. Professor Rachlinski, a prominent law and psychology scholar, argues that the deferential attitude of the courts to boards and shareholders in their decision-making shows that the courts are aware of their own inclination to be affected by hindsight bias when reviewing a past business decision that clearly led to a bad outcome. By the deferential business judgment rule, he contends, courts guard against their exercise of the bias. ${ }^{161}$

Related to this justification is the contention that, by their deference, judges recognize, in a practical way, the psychological and other complexities of such business decisions as mergers and accord considerable leeway to decision-makers who must navigate amid this complexity. Thus, judges at least understand that they could not make the business decisions any better than the actual players did. ${ }^{162}$ This is a kind of psychological rephrasing of the well-known concept of the courts' recognition of their limited institutional competence. By their deference, they acknowledge that they can sort out neither the business reasons

In this day and age in which investors also have access to an abundance of information about corporate transactions from sources other than boards of directors, it seems presumptuous and paternalistic to assume that the court knows better in a particular instance than a fully informed corporate electorate with real money riding on the corporation's performance.

Id.

${ }^{161}$ See Jeffrey J. Rachlinski, A Positive Psychological Theory of Judging in Hindsight, in BEHAVIORAL LAW \& ECONOMICS, supra note 26, at 95, 110-11.

${ }^{162}$ In a related vein, one could argue that the Unocal rule in Delaware jurisprudence could be justified as a way of allowing directors of a target corporation to resist the psychological pressures to take a bid ("myopia") by allowing them to draw back to consider other alternatives. See Unocal v. Mesa Petroleum Co., 493 A.2d 946 (Del. 1985). 
for merging nor the complex psychological and other factors affecting business people in these difficult decisions. ${ }^{163}$

Yet, as reasonable as this response is, it appears to be a psychological apology for the status quo. ${ }^{164}$ By relying upon a model of decision-making based upon rationality, courts clearly ignore the influence of psychological factors in decision-making, especially when they intervene only in the rare decision that they can characterize as irrational. ${ }^{165}$ In addition, the stark contrast between the rational and the irrational ignores the numerous ways in which psychological factors are intertwined with rationality in the quasi-rationality. ${ }^{166}$ And it is

${ }^{163}$ On the limitation regarding judicial intrusiveness, see 1 AMERICAN LAW INSTITUTE, PRINCIPLES OF CORPORATE GOVERNANCE 135 (1994); JAMES D. COX ET AL., CORPORATIONS 607 (1997).

${ }^{164}$ I owe this observation to Professor Christine Jolls. In a recent article, Professor Rachlinski exhibits more skepticism about the psychological "optimality" of existing legal nules. See Jeffrey J. Rachlinski, The "New" Law and Psychology: A Reply to Critics, Skeptics, and Cautious Supporters, 85 CORNELL L. REV. 739, 748 (2000). The status quo bias in current corporate law jurisprudence is also suggested (although on other grounds) by corporate law scholars who believe that corporate law, including the law dealing with takeovers, is favorable to corporate managers because those managers control incorporation decisions and decisions to continue a firm's incorporation in a particular jurisdiction. But see Daines, supra note 147, at 12-15 (presenting evidence that Delaware corporate law increases market value of firms). See generally Lucian Arye Bebchuk \& Allen Ferrell, Federalism and Corporate Law: The Race to Protect Managers from Takeovers, 99 COLUM. L. REV. 1168 (1999) (reviewing the arguments for managerial influence on takeovers). My argument on the need for courts to acknowledge psychological reality does not require that I take a position on these arguments, which go to the relative value of current or possible corporate laws. See id. at 38 ("Nor do these results show that Delaware law is better than a hypothetical Federal [sic] code or that all of Delaware's laws are optimal.").

${ }^{165}$ Professor Rachlinski points out that, apart from dealing with the hindsight bias, courts generally are weak in recognizing and addressing the influence of psychological factors. See Rachlinski, supra note 164 , at 756 . There are cases, however, particularly in the partnership context, when courts show a kind of common sense appreciation of the psychological background to a dispute. See, e.g., Juran v. Bron, No. 16464, 2000 Del. Ch. LEXIS 143, at *9 (Oct. 6; 2000), where the Chancery Court states:

As noted above, personality differences between Bron and Juran have driven, and continue to drive, this litigation. Their feud began during their tense and difficult negotiations regarding the Employment Agreement and Partnership Agreement. Following the second closing, an irreparable rift had developed between the two. It is apparent from record evidence and the testimony at trial, Juran's rigid, meticulous style simply clashed with Bron's more "fast and loose" approach.

${ }^{166}$ For example, many problems with defective decision-making have nothing to do with gathering information, but with processing (i.e., paying sufficient attention to) the information at hand. See, e.g., JANIS, supra note 42, at 174-75 (describing "symptoms of defective decisionmaking" due to "groupthink," such as "[f]ailure to examine risks of preferred choice," "[f]ailure to reappraise initially rejected altematives," "[s]elective bias in processing information at hand," and "[f]ailure to work out contingency plans"). 
contradictory for scholars to argue that courts have enough insight to recognize their own tendency to be influenced by psychological factors but not enough to detect the presence of these factors in others' decisions. It is possible for courts to acknowledge the existence of psychological factors by a rule that, rather than overly intruding upon the private ordering of a business decision, takes into account more realistically how in practice people make these decisions. ${ }^{167}$

A related justification for the current judicial approach in merger and other business decision-making is that people have done the best they can and, therefore, it is unwise to tamper with the approach. As the argument goes, managers, board members, and shareholders are always influenced by psychological factors, but they attempt to resist some and incorporate others all within a calculative rationality motivated by self-interest. ${ }^{168}$ This rationality with some psychological baggage, as developed over a long time, is the best available decision-making system. It is not perfect, but it will eventually take care of problems in a given business domain. Indeed, from an evolutionary perspective, this outcome might well be a remnant of prehistoric times and may be a highly effective manner of decision-making because it takes into account human cognitive limitations. ${ }^{169}$ For example, it may well be extremely adaptive for individuals to be optimistic, even over-optimistic, in business so as to be emotionally able to overcome frequent setbacks, to face risks, and to be ready to form cohesive groups that give them the support of a social network in difficult times. ${ }^{170}$ This optimism with its cohesiveness may help decision-makers respond quickly in business, especially in a time of industry shock brought about by rapidly changing technology, and thus triumph over their competitors.

This justification, which is also highly influenced by the status quo bias, is

${ }^{167}$ For an example of a proposed legal rule that takes into consideration psychological issues, see Donald C. Langevoort, Organized Illusions: A Behavioral Theory of Why Corporations Mislead Stock Market Investors (and Cause Other Social Harms), 146 U. PA. L. REV. 101, 157-63 (1997) (proposing that disclosure liability in a firm should not be limited to knowledge by top officials because often their knowledge is not crucial to the disclosure violation). See also James D. Cox \& Harry L. Munsinger, Bias in the Boardroom: Psychological Foundations and Legal Implications of Corporate Cohesion, 48 LAW \& CONT. PROB. 83, 132-34 (1985) (in this classic study on psychological biases that make board members sympathetic and partial to fellow board members, the authors discuss how this sympathy can undermine the independent litigation committee approach to derivative suits created under Delaware and other corporate laws; the authors propose to eliminate court reliance on a director recommendation with respect to a suit against a fellow director and, as an alternative, to have the special litigation committee appointed by a court); Fanto, supra note 10, at 334-51 (arguing for a legal nule that would require the negative consequences of the merger to be emphasized in board merger decision-making).

${ }^{168}$ Management literature attempts to improve this rationality so as to better board performance. See Carpenter \& Westphal, supra note 53, at 3-4.

${ }^{169}$ See Langevoort, supra note 167, at 152-56; Posner, supra note 21, at 1561-64.

${ }^{170}$ See LANGEVOORT, HUMAN NATURE, supra note 50, at 13 (explaining that "highly collegial groups create a better environment for productive work'). 
really an indirect form of confidence in the "invisible hand" of the market. ${ }^{171}$ From its perspective, the present form of business decision-making, as sanctioned by the courts, is thought to be the lowest-cost way of making good decisions and dealing with the psychological factors. Yet, once again, the justification raises more questions than it provides answers. What if the current system of decisionmaking is not the second best way of making decisions and accommodating psychological factors? ${ }^{172}$ Because of the evidence of the persistence of value destruction in mergers, and of the tendency of people either not to learn from their mistakes in mergers or other business decisions or to learn slowly only after much value destruction, ${ }^{173}$ can we really say that, at least with respect to this kind of decision-making, we have arrived at a truly second best solution? Although any legal reform must proceed cautiously so as to recognize the evolutionary adaptive nature of, and not to upset, beneficial uses of quasi-rationality in business decision-making, it would seem to be at the very least necessary, given the empirical evidence on the psychological factors, to consider how to make courts explicitly understand the complex psychological reality of this decision-making when articulating legal standards governing it. This understanding, which would be so different from the current simplistic judicial account of decision-making, would likely result in changes to these standards.

\section{B. Suggested Legal Responses to the Psychological Factors}

The above reflection leads to the inquiry on the proper guidance to offer courts and other legal policy-makers on a reform of the legal oversight of business decisions that recognition of the presence and strength of psychological factors requires. One problem is that most psychologically inspired work on legal reforms of defective decision-making is in public law, which deals with situations

${ }^{171}$ It thus is in agreement with the most prominent approach in business law scholarship. For example, even some scholars who criticize current Delaware corporate law on takeovers do so because it inappropriately constrains the working of the takeover market. See, e.g., RONALD J. GILSON, UNOCAL FIFIEEN YEARS LATER (AND WHAT WE CAN DO ABOUT IT) 13-14, 22 (Columbia L. Sch. Center for L. \& Econ., Working Paper No. 177, 2000), at http://papers.ssm.com/sol3/papers.cfm (Aug. 1, 2000) (arguing that Unocal and its progeny allows a target board to resist absolutely a tender offer, but not to preclude an election to replace the board, and that the better outcome would be to allow target boards to negotiate with bidders and then to let shareholders (i.e., the market) decide whether to accept the bid). This perspective completely glosses over the presence of psychological factors in board or shareholder decisionmaking.

${ }^{172}$ See Jolls et al., supra note 21 , at 1599-1600 (observing that the evolutionary argument is highly speculative and not always provable).

${ }^{173}$ See Langevoort, supra note 21 , at 1521 (referring to business context where feedback from bad decisions is not immediate and where people need to stress, despite setbacks, optimism and control); see also Carey, supra note 51, at 146 (providing remarks of Alex Mandl, CEO of Telegent, that dismissed out of hand studies of merger failure). 
where emotions are seen to nullify a rational consideration of policy alternatives. ${ }^{174}$ That world is seen as the opposite of the realm of business decisions inhabited by hard-nosed, cost/benefit rationality and self-interested capitalists focused on maximizing profits. The empirical results of this article, however, suggest that this kind of rationality is not even the paradigm in the business arena, and that psychological factors are inevitably intertwined with, and are not secondary to, a decision that one could also characterize as rational. ${ }^{175} \mathrm{An}$ effort to improve legal oversight of business decision-making might thus be especially important, particularly if, because of the popular and scholarly acceptance of the rationality paradigm in business, scholars are less vigilant about the presence and influence of psychological factors in this kind of decisionmaking and are all too ready to dismiss or to discount them heavily.

The refocused.inquiry, therefore, is to ask what legal reform is demanded by the quasi-rationality of current business decision-making and, more specifically for the purposes of this article, of mega-merger decision-making. At this stage, in light of the insufficiency of empirical results establishing a clear correlation or causation between specific psychological factors and poor merger decisionmaking and given other promising research efforts, ${ }^{176}$ it is advisable to tread slowly and not rush precipitately to advocate specific legal reforms. It might make more sense to establish the general goals of legal reform affecting merger decision-making that are inspired by the psychological data and then to offer a few concrete examples of possible specific legal changes. And these changes could be in the two areas of law governing this decision-making-corporate law and federal securities law. ${ }^{177}$

As a general matter, one of the goals is relatively easy to articulate and has already been suggested above: more understanding by courts and policy-makers

${ }^{174}$ The best representative of this kind of work is Professor Cass Sunstein. See, e.g., CASS R. SUNSTEIN, COGNITION AND COST-BENEFIT ANALYSIS (U. of Chicago John M. Olin L. \& Econ. Program, Working Paper No. 85, 1999), at http://papers.ssm.com/sol3/papers.cfm (Oct. 14, 1999).

${ }^{175}$ Courts may occasionally acknowledge the influence of emotions in decision-making, but consider them as a secondary influence. See, e.g., Harbor Finance Partners v. Huizenga, 751 A.2d 879, 889 (Del. Ch. 1999) (discussing motivating factor of familial relations in decisionmaking); HMG/Courtland Properties, Inc. v. Gray, 749 A.2d 94, 119 (Del. Ch. 1999) ("When he does so [represent family members' interests], I have no doubt that Fieber attempts to protect his family members' financial interests no less avidly than he attempts to protect his own."). From a rational (and even genetic) perspective, of course, family interest may be no different from self-interest. See PINKER, supra note 29, at 44 (claiming that the human goals of enjoying health, life, sex, and family allow genes to survive across generations).

${ }^{176}$ One related promising avenue of understanding and improving decision-making is scholarship on the effects of norms. See, e.g., Scott, supra note 46, at 16 ("The more we leam about norms, therefore, the more we should demand evidence of the comparative inadequacy of these extralegal constraints on behavior before we impose additional, legal constraints.").

${ }^{177}$ The examples of possible legal reform provided below would thus be in addition to those offered in Fanto, supra note 10, at 331-51. 
of the psychological complexity of decision-making. It is also not difficult to imagine ways of implementing this goal, such as giving judges and others general training in psychology (offered by an expert, such as Professor Rachlinski). A second goal is just as easy to articulate-to regulate decision-making in order to address the adverse effects arising from the psychological factors-but its implementation is not as clear. As a general implementation framework for this goal, it is helpful to use an approach proposed by two prominent scholars in the law and psychology arena, Timur Kuran and Cass Sunstein. They propose that decision-making should try to achieve a "comprehensive rationality" that is designed to resist adverse effects of the psychological factors, particularly the social "cascades" of adoption of a point of view that might flow from myopia; biases, such as loss aversion or extremeness aversion; or heuristics, such as anchoring. ${ }^{178}$ This kind of rationality would mean, among other things, having decision-makers critically compare alternative plans of action before deciding upon one, subject the selected course of action to considerable scrutiny for its risks, and constantly re-evaluate the elected course for possible reasons to change it. ${ }^{179}$ The framework would also involve strengthening the role of any available science or discipline relevant to the decision-making. ${ }^{180}$

Achievement of any "comprehensive rationality," moreover, must be done with care, not with its own over-optimism, and with sensitivity to psychological constraints and to the power of the psychological factors. Simply compelling people to consider more information does not necessarily mean better decisionmaking, especially in light of findings that further deliberation does not necessarily make people reassess their viewpoints. ${ }^{181}$ It is also important not to undermine the positive, adaptive aspects of psychological factors that help make people productive. ${ }^{182}$ The goal would be to enhance the behavior of a decisionmaker, like a board member, where he or she is already acting seriously and in good faith. ${ }^{183}$

${ }^{178}$ See Kuran \& Sunstein, supra note 44, at 748.

${ }^{179}$ This approach would echo proposals on resisting "groupthink" which suggest that a policy should be arrived at only after much contentious debate and exposure to criticism of all viewpoints. See JANIS, supra note 42, at 132-58, 260-71 (discussing resistance to groupthink in Kennedy administration's dealing with the Cuban missile crisis).

${ }^{180}$ See, e.g., SUNSTEIN, supra note 174, at 9-19 (explaining how a cost/benefit analysis can address problems arising from psychological factors).

${ }^{181}$ See Korobkin \& Ulen, supra note 21, at 1094 (explaining that "people seem to use more evidence to solidify their views, rather than to alter them").

${ }^{182}$ See LANGEVOORT, HUMAN NATURE, supra note 50, at 14; Rachlinski, supra note 164, at 753 ("Finally, many of the psychological phenomena are quite adaptive. If these phenomena are mental shortcuts that serve people well, or even enhance their well-being, then crafting legal rules that induce people to avoid them could do more harm than good.").

${ }^{183}$ See, e.g., Jonathan L. Johnson et al., Boards of Directors: A Review and Research Agenda, 22 J. MGT. 409, 427 (1996) ("Perhaps the greatest support for the service role lies in directors' self-reports that they devote a considerable proportion of their board-related time and 
Here it is useful to offer a few examples of how the law does not lead to, and even undermines, comprehensive rationality and how it might be changed to achieve this goal. The first example comes from both federal securities and state corporate law. Many of the statements in the SEC documents that reveal the presence of the psychological factors are, in securities law parlance, "forwardlooking" statements because they look towards, or forecast, the future. For instance, firms' over-optimistic discussions of merger synergies or their justification of a transaction as addressing potential changes in an industry and a potential loss of competitive position (loss aversion), which appear, among other places, in the "Reasons For the Merger" section of the document, would fall into this category. As noted earlier, the predictions are free of securities law liability so long as they are accompanied by language cautioning a shareholder that the foretold events or results may never occur. ${ }^{84}$ Accordingly, it is standard practice for a Form S-4 or Schedule 14A to include language in which the parties preparing the disclosure documents claim legal protection for the forward-looking statements. ${ }^{185}$

effort to contributing to corporate decision making.").

${ }^{184}$ See supra note 126 and accompanying text. Moreover, similar reasoning is used under Delaware's corporate law duty of disclosure. If shareholders receive even boilerplate warnings about the risks involved in the predictions, then boards satisfy their legal obligations. See Solomon v. Armstrong, 747 A.2d 1098, 1130 (Del. Ch. 1999) ("Where clear and explicit language has the incontrovertible effect of changing or modifying meaning, I cannot ignore that meaning. This is true even if such qualifying language is routinely employed in disclosure statements that tout potential benefits.").

${ }^{185}$ The following example is typical:

This joint proxy statement-prospectus contains "forward-looking statements" within the meaning of the Private Securities Litigation Reform Act of 1995. These statements may be made directly in this joint proxy statement-prospectus or they may be made a part of this joint proxy statement-prospectus by appearing in other documents filed with the Securities and Exchange Commission by Chase and J.P. Morgan and incorporated by reference in this joint proxy statement-prospectus. These statements may include statements regarding the period following completion of the merger.

Words such as "anticipate," "estimate," "expect," "project," "intend," "plan," "believe," "target," "objective," "goal" and words and terms of similar substance used in connection with any discussion of future operating or financial performance of Chase, J.P. Morgan or J.P. Morgan Chase \& Co. or the merger identify forward-looking statements. All forward-looking statements are management's present expectations of future events and are subject to a number of factors and uncertainties that could cause actual results to differ materially from those described in the forward-looking statements. In addition to the factors relating to the merger discussed under the caption "Risk Factors" above, the following risks related to the businesses of Chase and J.P. Morgan, among others, could cause actual results to differ materially from those described in the forward-looking statements: the risk of adverse impacts from an economic downturn; increased competition; unfavorable political or other developments in foreign markets; governmental or regulatory policies; market volatility in securities markets, interest or foreign exchange rates or indices; other factors impacting our operational plans; or legislative or regulatory developments. 
Shareholders of the acquiring and target firms have natural, rational reasons to want to know what their board members and CEOs think about the future prospects of the mega-merger. And, as just described, the law encourages the provision of this kind of information. However, it also-no doubt unintentionally-allows corporate fiduciaries to make full use of the psychological factors to influence shareholders' decision-making. ${ }^{186}$ Some resistance to the psychological factors on the shareholders' part is stimulated by the cautionary language and the required presentation of the transaction's risks in the SEC documents. How influential can the psychological factors be on shareholders if there are detailed warnings that a particular transaction may not succeed or that it may not produce the intended effects?

However, the presentation of the negative may not be psychologically effective when the use of the psychological factors enhances such a positive view of the transaction. Because the positive has been so enhanced, both in the original announcement of the transaction and in the Form $\mathrm{S}-4$ or Schedule 14A, shareholders will likely anchor to it and completely overlook or discount the negative, as the board had done before them. ${ }^{187}$ Moreover, there may well be qualitative differences in the psychological presentation of the positive and negative. For one salient example, negative consequences of the transaction are generally not quantified. For example, there is no prediction of the losses that could arise from the transaction as the competitive position of the combined firm erodes. Yet, without some highlighting of these losses or costs, the effect of the psychological factors cannot be adequately reduced, and even this kind of presentation may not alone be sufficient to counterbalance the factors' effects. It

We caution you not to place undue reliance on the forward-looking statements, which speak only as of the date of this joint proxy statement-prospectus, in the case of forwardlooking statements contained in this joint proxy statement-prospectus, or the dates of the documents incorporated by reference in this joint proxy statement-prospectus, in the case of forward-looking statements made in those incorporated documents.

For additional information about factors that could cause actual results to differ materially from those described in the forward-looking statements, please see the quarterly reports on Form 10-Q and the annual reports on Form 10-K that Chase and J.P. Morgan have filed with the Securities and Exchange Commission as described under "Where You Can Find More Information."

WE EXPRESSLY QUALIFY IN THEIR ENTIRETY ALL FORWARDLOOKING STATEMENTS ATTRIBUTABLE TO EITHER OF US OR ANY PERSON ACTING ON OUR BEHALF BY THE CAUTIONARY STATEMENTS CONTAINED OR REFERRED TO IN THIS SECTION.

CHASE/J.P. MORGAN FORM S-4, supra note 79, at 19-20.

${ }^{186}$ Indeed, for a long time the SEC opposed the provision of forward-looking information, which opposition it based upon the ever-present possibility of "puffing" by companies about their future prospects. See generally JAMES D. COX ET AL., SECURITIES REGULATION: CASES AND MATERIALS 71-73 (2d ed. 1997). The SEC may have understood in a rough psychological way that this kind of language inevitably highlights aspects of quasi-rationality over rationality.

${ }^{187}$ See Korobkin \& Ulen, supra note 21 , at 1100-05. 
thus is psychologically inappropriate, because of their failure to promote or achieve a comprehensive rationality, for federal securities law and state corporate law to permit the psychological enhancement of the positive without imposing the risk of liability merely because the positive presentation is "balanced" by a presentation of the negative. ${ }^{188}$

Furthermore, current law permits disclosure documents to be oriented towards the positive and thus undermines the promotion of a comprehensive rationality in the shareholders and among board members. It is well established under federal securities law that corporate officers who seek shareholder approval of a particular course of action are under no obligation to argue against the action that they recommend or to present every potential negative consequence that might arise from the transaction. ${ }^{189}$ Similarly, under the Delaware corporate law duty of disclosure, a board does not have to include speculative or abandoned possibilities other than the recommended course when requesting shareholder action. ${ }^{190}$ The board has only to make adequate disclosure about its proposal,

${ }^{188}$ E.g., In re Newell-Rubbermaid, No. 99-C-5853, 2000 U.S. Dist. LEXIS 15190, at *26*30 (N.D. Ill. Oct. 4, 2000).

${ }^{189}$ See, e.g., Desaigoudar v. Meyercord, 223 F.3d 1020, 1024 (9th Cir. 2000) ("Section 14(a) and Rule 14a-9 do not obligate corporate officials to present, no matter how unlikely, every conceivable argument against their own recommendations."). This kind of logic appears throughout the SEC's rules promulgated under Section 14(a) and is founded on the basic corporate law concept that board members, not shareholders, control the corporation. For example, the board is under no obligation to accept from a shareholder a proposal that is counter to one that it has proposed. See 17 C.F.R. $\$ 240.14 a-8(i)(9)$ (2001).

${ }^{190}$ See, e.g., State of Wisconsin Investment v. Bartlett, No. 17727, slip op. at 28 (Del. Ch. Feb. 24, 2000) ("The mere existence of unrequited attraction with other entities does not lead to acceptance of plaintiff's assertion of materiality - namely that shareholders would then know other deals might be possible and that there might be better options than the King merger agreement."). See, for example, O'Reilly v. Transworld Healthcare, Inc:

Furthermore, while it is not necessary for the resolution of this motion, I note that it does not appear that the duty of disclosure would obligate corporate fiduciaries to disclose information regarding whether a merger represents the highest value available to a corporation when the corporation has received, or its directors have obtained, only one offer. While under certain circumstances a board's failure to obtain, through an auction of the company, the most valuable offer available to the stockholders may constitute a violation of their duties under Revlon v. MacAndrews \& Forbes Holdings, Inc., the duty of disclosure does not appear to require them, when they have received only one offer, to disclose information from which the stockholders could assess whether the offer represents the highest value reasonably available to the company's stockholders, as opposed to whether the offer at issue represents fair value.

745 A.2d 902, 929 (Del. Ch. 1999) (citing Revlon v. MacAndrews \& Forbes Holdings, Inc., 506 A.3d 173 (Del. 1986)); In re Lukens, Inc. Shareholders Litig., 757 A.2d 720, 736 (Del. Ch. 1999) ("What the proxy statement does not do is explain why the board chose not to take particular courses of action. Of course, requiring disclosure of every material event that occurred and every decision not to pursue another option would make proxy statements so voluminous that they would be practically useless."). 
which will enable shareholders to decide, on their own, whether or not to follow this advice. ${ }^{191}$ Indeed, in presenting its recommendation that shareholders approve a transaction like a merger, a board need not discuss in detail the transaction's background, which might otherwise raise the issue of alternative and rejected courses of action. ${ }^{192}$

How can federal securities law and state corporate law change to increase comprehensive rationality in merger decision-making without a radical transformation in the law? As noted earlier, psychological research establishes that a radical change is unlikely to be either proposed or accepted, for people are rarely willing to undertake more than incremental changes in non-emergency situations. With respect to federal securities law, the preferred approach, because of its likely success, would be for the SEC to strengthen disclosure in a way that would counter the influence of the psychological factors on shareholders and on the board. To take one prominent example, throughout Form $S-4 s$, the customary boilerplate language found generally at the end of each section on a particular board's "Reasons for the Merger" is that, after listing all the factors relevant to the merger decision, there has been no attempt to identify which factor a particular director thought to be important, and the board has not assigned a particular weight to an enumerated factor in its decision-making. ${ }^{193}$ Yet under this approach, a board member can hide behind a group decision, and the board itself is under no obligation to give a detailed account of its decision-making and explain which of the listed factors were most significant.

\footnotetext{
${ }^{191}$ See, e.g., In re G.M. Class H Shareholders Litig., 734 A.2d 611, 626 (Del. Ch. 1999) (referring to choice of shareholders to accept or reject board's recommendation).

${ }^{192}$ See, e.g., Matador Capital Mgmt. v. BRC Holdings, 729 A.2d 280, 295 (Del. Ch. 1998) ("The application of [the disclosure] standard does not require a blow-by-blow description of events leading up to the proposed transaction."); id. at 297 ("Nor need [the disclosure document] disclose the details of the board's discussions and deliberations."); Newman v. Warren, 684 A.2d 1239, 1246 (Del. Ch. 1996) (no requirement of disclosure of views of directors who opposed transaction). Again, DEL. CODE ANN., tit. 8, § 102(b)(7) (2000) extinguishes any claim for damages based on a violation of the duty of care as well as related violations of the duty of disclosure, and a fully-informed shareholder vote approving a merger may well extinguish most claims for a breach of fiduciary duty. See, e.g., Lukens, 757 A.2d at

${ }_{193}^{732-35,737-38 .}$ For example, in giving its reasons for AOL's merger with Time Warner, the AOL board states:
}

This discussion of the information and factors considered by the America Online board is not intended to be exhaustive, but includes the material factors considered. The America Online board did not assign particular weight or rank to the factors it considered in approving the merger. In considering the factors described above, individual members of the America Online board may have given different weight to various ones. The America Online board considered all these factors as a whole, and overall considered them to be favorable to and to support its determination.

See AOL/TIME WARNER FORM S-4, supra note 92, at 33. 
One possible reform is for the SEC to require a company proposing a megamerger to disclose the board's assignment of a numerical weight and order of importance to each of the enumerated reasons for and against the transaction. ${ }^{194}$ This approach, which is not intended to suggest the correct weight to be given to a specific reason or reasons a board should consider, is designed to stimulate a comprehensive rationality on the board's part. This rationality would in turn be conveyed to the shareholders and help produce a similar rationality in them. It would thus not assume that rationality exists-or quasi-rationality can be adequately addressed-simply because a board lists the information or factors that it has considered in its decision-making and that shareholders should understand to be important. ${ }^{195}$ Instead, this approach assumes that the psychological factors and the group momentum they create may be countered only when a board member or shareholder is pulled out of the group framework by being forced to consider critically a proposed transaction and confront negative information about it. ${ }^{196}$

A complementary reform to the above SEC effort would involve a reformulation of the "duty of disclosure" under Delaware corporate law, as interpreted by the Delaware Chancery Courts. Under the fiduciary principles that provide the basis for this duty, ${ }^{197}$ a court might well hold that a board's disclosure

${ }^{194}$ The SEC's intervention is justified here because the role of government would be to affect a process that is socially disadvantageous (to stop the "cascade" of mergers). See CASs R. SUNSTEN \& EDNA ULLMANN-MARGALIT, SOLIDARITY IN CONSUMPTION 17-18 (U. of Chicago John M. Olin L. \& Econ. Program, Working Paper No. 98, 2000), at http://papers.ssrn.com/sol3/papers.cfm (May 3, 2000) (giving a broad definition of the "good" to include practices and suggesting that when a practice becomes social, but is harmful, the government can intervene to push society to reject the practice). The "market," as represented by buyers or sellers as well as by private norm agents outside government who are currently criticizing mega-mergers, may ultimately achieve the goal of addressing the psychological factors, but for various reasons they are not succeeding now. See Fanto, supra note 10, at 29598.

${ }^{195}$ Occasionally, a Form S-4 will achieve an approximation of this proposal. See, e.g., PFIZER/WARNER-LAMBERT FORM S-4, supra note 81, at I-35-46 (weighing various reasons for and against the merger). This presentation may be due to the fact that the merger came from a contested bidding situation and spawned shareholders' lawsuits.

${ }^{196}$ Board discussions about the proper ordering and consideration of factors arguing for and against a merger may also stimulate more board critical analysis of the transaction. Other improvements to disclosure, which would affect board and shareholder behavior, are imaginable. The SEC could require a detailed cost-based analysis of the negative consequences potentially arising from the merger. Naturally, the SEC would have to be careful in its enhanced disclosure not to undermine board solidarity and thus harm well-functioning, cohesive boards. See LANGEVOORT, HUMAN NATURE, supra note 50, at 30 ("When the law becomes too aggressive, it risks altering the social dynamic of the board in a way that makes it less effective as a working group."). It might do this by placing less emphasis on the factors influencing individual board members (unless they were relevant) and more emphasis on a quantified presentation of all factors material for the entire board.

${ }^{197}$ See O'Reilly v. Transworld Healthcare, Inc., 745 A.2d 902, 925 (Del. Ch. 1999) 
to shareholders on a proposed transaction must be appropriately balanced. To fulfill the duty, the board should not offer one-sided, unfocused advocacy of its desired course of action, but it must explain in detail, and in their order of importance, the arguments against its position and its specific reasons for rejecting them. Again, this legal reform would be more legally significant-and thus more difficult to achieve-than the SEC's enhanced disclosure since it would run counter to accepted court interpretation of this duty that directors need not argue against their recommended course of action. ${ }^{198}$

Another possible disclosure reform designed to further comprehensive rationality in decision-making would involve the faimess opinions of investment bankers. As explained earlier, a board of directors of a company involved in a merger, particularly the target company, almost always seeks an opinion from an investment banking firm on whether the exchange ratio is "fair" to the company's shareholders. ${ }^{199}$ Indeed, investment bankers are sometimes critical for the instigation and design of a particular transaction. ${ }^{200}$ Yet in the typical investment banking opinion, investment bankers give their opinion in artistic, not scientific, terms. They suggest, for example, that no deal is similar to another and, as in a board's summary of its reasons for a merger, they make no effort to identify the factors in order of importance that influenced their opinion. ${ }^{201}$ Certainly, this

('Stockholders should be entitled to rely on the truthfulness of statements in communications from corporate fiduciaries without having to question each representation against potentially conflicting statements or facts that would lead to conflicting conclusions.").

${ }^{198}$ Yet there is certainly language in Delaware court decisions that could be read to support the proposal. See Malone v. Brincat, 722 A.2d 5, 12 (Del. 1998) ("Directors are required to provide shareholders with all information that is material to the action being requested and to provide a balanced, truthful account of all matters disclosed in the communications with shareholders.") (emphasis added). From a procedural perspective, moreover, the proposal is workable since, upon a plaintiff's motion for an injunction against a transaction proceeding with faulty disclosure, a court could mandate that the disclosure be revised. See, e.g., Matador Capital Mgmt. v. BRC Holdings, 729 A.2d 280, 296-97 (Del. Ch. 1998) (ordering target company to revise Schedule 14D-9 to reflect actual board deliberations, actions, and reasons regarding their support of a tender offer).

${ }^{199}$ See supra note 128 and accompanying text.

${ }^{200} \mathrm{~A}$ good example is the story of the role of the investment bankers in the Daimler/Chrysler merger, as recounted in VLASIC \& STERTZ, supra note 54, at 53 (role of the Deutsche Bank); id. at 78 (role of Bank of America); id. at 212-14 (role of First Boston).

${ }^{201}$ A typical example is that offered by Chase Securities, which provided a faimess opinion to Chase in its merger with J.P. Morgan:

The preparation of a faimess opinion is a complex process and involves various judgments and determinations as to the most appropriate and relevant assumptions and financial analyses and the application of these methods to the particular circumstances involved. Such an opinion is therefore not readily susceptible to partial analysis or summary description and taking portions of the analyses set out above, without considering the analyses as a whole, would, in the opinion of Chase Securities, create an incomplete and misleading picture of the processes underlying the analyses considered in rendering Chase Securities' opinion. Chase Securities did not form an opinion as to 
language is designed to deflect liability if the transaction turns out badly by having the bankers remain somewhat vague about the sources of their opinion. As a result, they cannot later be accused of overemphasizing one factor and missing another. And the opinions, which are attached as exhibits to the Form S-4, are detailed in their analyses. However, the vagueness of the statements in the opinions does nothing to counter the psychological factors, which, as seen in the case of anchoring, it actually promotes.

The SEC might consider a disclosure rule that would hold investment bankers to a higher standard in their opinions by requiring them to consider the potential negative consequences and costs arising from the transaction and to quantify the likely negative results of the merger. In the same vein, investment bankers could be required to give an opinion that explicitly addresses the rationality of the deal from both the acquirer's and target's perspective as opposed to their current limited focus on the faimess of the exchange ratio. After all, since they are so involved in promoting the mega-mergers, it is appropriate for them to be enlisted in the effort to achieve a comprehensive rationality on the part of boards and shareholders. In addition, by expanding their opinions to address the evidence on the negative results of mega-mergers, investment bankers would enhance the comprehensive rationality of merger decision-making. They would also present a stronger scientific rationale than that contained in the watereddown, self-interested version of financial economics currently used to justify their fairness opinions. ${ }^{202}$

The most important reform proposal would have to address the present deferential attitude of the courts to merger decision-making when they apply corporate law and their equity jurisprudence. This application does little to counter the effects of the psychological factors. ${ }^{203}$ As discussed above, courts

whether any individual analysis, considered in isolation, supported or failed to support Chase Securities' opinion. In arriving at its opinion, Chase Securities considered the results of all such analyses and did not assign specific weights to particular analyses. The analyses performed by Chase Securities, particularly those based on forecasts, are not necessarily indicative of actual values or actual future results, which may be significantly more or less favorable than suggested by such analyses. Such analyses were prepared solely as part of Chase Securities' analysis of the fairness, from a financial point of view, to Chase's stockholders of the exchange ratio in the merger. The foregoing summary is qualified in its entirety by reference to the full text of Chase Securities' opinion.

CHASE/J.P. MORGAN FORM S-4, supra note 79, at 36.

${ }^{202}$ Cf. Kuran \& Sunstein, supra note 44 , at 748 (discussing the need for a scientific approach to counter psychological influences). See generally WILLIAM MEADOW \& CASS R. SUNSTEIN, STATISTICS, NOT EXPERTS (U. of Chicago John M. Olin L. \& Econ. Program, Working Paper No. 109, 2000) (unpublished manuscript), at http://papers.ssm.com/sol3/paper.cfm (Dec. 8, 2000) (arguing for a reliance upon statistical data, rather than expert opinions, since these opinions tend to be affected by over-optimism).

${ }^{203}$ This is related to the issue of the design of the best board of directors, a goal that is difficult to reach given the difficulty of doing empirical research on what makes a board 
generally defer to board decisions and intrude little in board decision-making, other than to ensure that boards have appropriately gathered information, ${ }^{204}$ and the deferential approach helps explain the psychological one-sidedness of a typical Form S-4. Even under enhanced judicial scrutiny-which is not involved in most mega-mergers - a court simply reviews whether a board's decision is reasonable within the range of alternatives, rather than asking whether the board made the best decision. ${ }^{205}$ If, in its deferential review, a court happens to consider momentarily the transaction, the outcome of its consideration is pre-ordained precisely because of the use of the psychological factors, particularly framing. That is, expressing the merger with the help of the psychological factors invariably makes the merger appear rational to the CEOs, the board, shareholders, and even to the courts! $!^{206}$

This reform would be difficult, for it runs counter to a longstanding status quo of corporate law and to courts' interpretations of it and of their own equitable powers. But the reform is not inconceivable. In an earlier article, I proposed

function well. See generally Benjamin E. Hermalin \& Michael S. Weisbach, Boards of Directors as an Endogenously Determined Institution: A Survey of the Economic Literature (June 15, 2000) (unpublished manuscript), at http://papers.ssm.com/sol3/papers.cfm (June 29, 2000) (discussing empirical results on boards from an economic and finance perspective).

${ }^{204}$ See Brehm v. Eisner, 746 A.2d 244, 264 (Del. 2000). The court writes:

As for the plaintiffs' contention that the directors failed to exercise 'substantive due care,' we should note that such a concept is foreign to the business judgment rule. Courts do not measure, weigh or quantify directors' judgments. We do not even decide if they are reasonable in this context. Due care in the decisionmaking context is process due care only. Irrationality is the outer limit of the business judgment rule. Irrationality may be the functional equivalent of the waste test or it may tend to show that the decision is not made in good faith, which is a key ingredient of the business judgment rule.

Id.; Ash v. McCall, No. 17132, 2000 Del. Ch. LEXIS 144, at *26 (Del. Ch. 2000) ("To analyze this claim under the waste standard confuses the due care standard with substantive due care-a concept that is foreign to the business judgment rule. Due care in the decision-making context is process due care-whether the board was reasonably informed of all material information reasonably available at the time it made its decision."); McMillan v. InterCargo, 768 A.2d 492, 505 (Del. Ch. 2000) ("Whether it is wiser for a disinterested board to take a public approach to selling a company versus a more discreet approach relying upon targeted marketing by an investment bank is the sort of business strategy question Delaware courts ordinarily do not answer.").

${ }^{205}$ See Paramount Communications Inc. v. QVC Network, 637 A.2d 34, 48 (Del. 1993) (citing Unocal Corp. v. Mesa Petroleum, 493 A.2d 946, 955-56 (Del. 1985) ("[A] court applying enhanced judicial scrutiny should be deciding whether the directors made $a$ reasonable decision, not $a$ perfect decision. If a board selected one of several reasonable altematives, a court should not second-guess that choice even though it might have decided otherwise.... [C]ourts... will determine if the directors' decision was, on balance, within a range of reasonableness.").

${ }^{206}$ See Brehm, 746 A.2d at 265 (the Delaware Supreme Court, while stating that it does not evaluate the alternatives facing the Disney board regarding its president, in fact presents the path chosen by the board as the most reasonable in the circumstances). 
adoption of an intermediate standard of judicial review of a board decision to engage in a mega-merger and explained how the standard could be seen to be consistent with current law. ${ }^{207}$ Under this standard, courts could encourage boards to improve the process of merger decision-making by ensuring that boards were aware of the psychological factors and adopted procedures to accommodate them and resist psychological momentum. The earlier suggestion about a revised judicial view of the duty of disclosure in a merger context would be another step in corporate law reform consistent with this proposal.

The best corporate law reform, however, may simply be to allow courts to become aware of the findings of psychological literature, which show them the effects of psychological factors and the inadequacy of their own view of rationality based solely upon information processing, and of the evidence of negative merger outcomes. Certainly, at times courts have shown themselves to be psychologically sensitive to business situations and able to conduct hard-nosed evaluations of business strategies where they think judicial intervention is justified. $^{208}$ With an enhanced psychological understanding and with more disclosure available about board decision-making, courts may develop their jurisprudence on merger decisions in incremental and unexpected but important ways. For example, they may begin to expand their understanding of what constitutes an appropriate decision-making process for a board about to engage in a mega-merger so that the process is not limited to information gathering but requires the board to make a showing that it addressed psychological factors.

Similarly, courts could augment the extremely small category of "irrational" decisions to include those where boards did nothing more than gather information, cite reasons for the merger in no particular order of importance, and fail to consider the influence of psychological factors on their decision-making. From a psychological perspective, in the absence of numerous merger disasters that would create a crisis mentality, courts will not likely change their review of

${ }^{207}$ See Fanto, supra note 10, at 333-51.

${ }^{208}$ On psychology, see Chesapeake Corp. and Sheffield, Inc. v. Shore, 771 A.2d 293, 328 (Del. Ch. 2000) (pointing out that the substantive coercion argument regarding shareholders may be overused: "Our law should also hesitate to ascribe rube-like qualities to stockholders. If stockholders are presumed competent to buy stock in the first place, why are they not presumed competent to decide when to sell in a tender offer after an adequate time for deliberation has been afforded to them?"); id. at 97 ("There is always the possibility that subjectively wellintentioned, but nevertheless interested directors, will subconsciously be motivated by the profoundly negative effect a takeover could have on their personal bottom lines and careers."). On evaluation of strategic altematives (when there is a claim of self-interest), see Strassburger v. Earley, 752 A.2d 557, 573-76 (Del. Ch. 2000) (critically reviewing and rejecting defendants' assertion that alternatives to a self-interested shareholder buy-back were seriously considered); HMG/Courtland Properties, Inc. v. Gray, 749 A.2d 94, 116-18 (Del. Ch. 1999) (discussing alternatives available to corporation regarding the sale of its properties when considering a faimess claim against a director who, with others, purchased the property through his familycontrolled corporation). 
mergers overnight. Change will probably come only after judges become aware of their own uncritical acceptance of the influence of the psychological factors. ${ }^{209}$

\section{CONCLUSION}

The empirical study of this article shows that psychological factors are forcefully present in merger decision-making. This finding suggests that the factors influence the outcome of the decision, even if the extent of this influence is unclear and if the exact relationship between the factors and poorly performing mega-mergers cannot be established from the study itself. The finding, however, is important because merger decisions, more than many business decisions, are used as the paradigm of decision-making by rational actors. By contrast, this article's study reveals that basic impulses, biases, and mental shortcuts that influence rational activity and transform it into quasi-rational behavior lie at the very heart of this mental activity. Moreover, in light of the overwhelming evidence available from this study and others that mergers in general decrease value for shareholders, it is fair to assume that there is some relationship between the psychological factors and the negative results of these transactions.

State corporate law and federal securities law, however, do not usually acknowledge the presence of the psychological factors or the quasi-rational framework in mega-merger decision-making. Rather, they presume that board members and shareholders make rational decisions so long as they engage in information processing and make no extremely bizarre decisions. Courts and the SEC thus rarely intrude upon merger decisions, and this deference blinds them to the quasi-rationality that is at work in the transactions.

On the basis of both its study and past studies in this ongoing research project, this article argues that there is a need for a fundamental reconsideration of how courts and securities regulators review mega-merger decision-making in producing and applying corporate and securities laws. It offers several examples of possible legal reform, which are designed to produce a comprehensive rationality in the boardroom that will also benefit shareholders when they vote on a transaction. With more detailed empirical research, the reform proposals should make board members focus on negative consequences of the transaction and should stimulate more debate in the board room. Board members will then be more likely to address better the influence of specific psychological factors. Moreover, much legal improvement may naturally result if those who make legal decisions become more aware of the influences of psychological and behavioral factors on merger decision-making.

${ }^{209}$ An economic downtum or recession might spur this judicial analysis by bringing even more rapidly to the foreground the inevitable negative results of mega-mergers. See, e.g., Dealmaking Done, ECONOMIST, Jan. 27, 2001, at 71 (discussing trouble at Bank of America and other banks formed from mega-mergers). 


\section{APPENDIX A}

\section{Psychological Issues \& Merger DeCISION-MAKING}

1. Myopia (also known as "focus on the present"): People often focus on the present to the exclusion of the future. They are impulsive and short term in nature. This is not a cognitive problem, as much as it is an impulse or emotional issue.

Comment: In merger decision-making, this could be represented by the desire to respond to a recent change in the industry that, although portrayed as important or even "path-breaking," may be seen to be relatively unimportant when judged from a long-term perspective. There is evidence that many mergers are "reactive" in nature (e.g., a firm merges because its competitors have merged); mergers could be "impulsive."

\section{Bounded Rationality}

a. Loss aversion: People are more displeased with losses than pleased with gains. People become attached to what they have ("endowment effect"). They are · very averse to a loss of the status quo. This is the realm of "prospect theory": people are simply not rational in their preferences or in their calculations and they do not act as rational economic actors. Another way of expressing this cognitive issue is to call it a "bias" (see infra). It is a "status quo bias" or, put another way, an attachment to things as they are.

Comment: A typical example of this in merger decision-making would be to justify a merger as necessary to maintain a company's current position in the industry (i.e., that if it does not do the transaction, it will not keep up with its competitors and/or will not maintain its competitive position). Another example is that if the firm is a leader in the industry, it must "do the merger" to maintain its leadership position. This factor may explain why firms so often cling to the same management and continued existence of headquarters. Firms are willing to take risks to maintain the status quo.

b. Biases: These are ways of viewing the world that distort facts. These are cognitive, as opposed to impulse, errors.

(1) Extremeness Aversion: People do not like extremes and tend to select the "middle" strategy or outcome.

Comment: This bias is not immediately obvious in merger decision-making. Yet it would be the case if the merger is presented as a balanced response to events with the decision-making grid as follows: (1) first extreme, doing nothing; (2) second extreme, doing other transactions or trying to develop capacity in a particular product on one's own; and (3) the merger (the middle outcome).

(2) Over-optimism: People tend to be unrealistically optimistic about 
themselves and their own abilities.

Comment: This is the classic explanation for value-decreasing mergers and will likely be evidenced throughout Form S-4s and other company statements about the merger. Even a seemingly neutral assessment of the likely growth of the two companies is usually highly colored by optimism (for example, the observation that the firm will succeed after the merger if everything goes right).

(3) Hindsight Bias: People often feel that what happened is inevitable. They feel that a past event is more predictable than in fact it was.

Comment: This may be a difficult bias to detect in merger decision-making, which deals with predicting a future event, not re-predicting a past one. It is usually exemplified when one is trying to blame someone for not foreseeing certain consequences that, in retrospect, seem inevitable (e.g., "You should have known that if you did this, you would cause this harm, because the harm actually occurred."). Perhaps it might appear as a justification for a merger as follows: earlier management should have seen the development of the industry in one direction; they did not; and we, the current management, are trying to address past failings.

(4) Status Quo Bias: See "Loss Aversion," supra.

c. Framing Effects: Peoples' preferences can be manipulated. For example, people can be encouraged to select an outcome because it is framed to be the middle choice (extremeness aversion) or a strategy because it is framed to be designed to avoid a loss (loss aversion).

Comment: If we find certain biases or other psychological factors, such as loss aversion, we should be able to point out how the proxy statements and Form $\mathrm{S}-4 \mathrm{~s}$ are creating them by framing; i.e., recognizing that the statements are written in a particular way to elicit psychological reactions.

d. Heuristics: Ways of thinking that people use to simplify tasks, which can sometimes produce poor results.

(1) Availability Heuristic: People think that something is more likely to happen or is more likely to be a problem if they can call it readily to mind. This also explains "herd behavior" as people find to be more likely what others are talking about (the "availability cascade").

Comment: A simple example of this is the justification of a merger by reference to a merger of competitors, to some industry shock, or to a regulatory change. Generally, once a merger occurs in an industry, it is followed by numerous other transactions. Industry analysts and investment bankers articulate the need for other transactions based on a past transaction or some current event (e.g., oil mergers were necessary because of the drop in the price of oil). 
(2) Anchoring: People make judgments based on an initial value or "anchor" that may be arbitrarily chosen, such as a value from their personal lives or initial impressions.

Comment: One example of anchoring in merger decision-making would be a merger justified by a given prior transaction of a competitor. If a competitor does a mega-merger at a given price, this becomes the anchor or measuring stick for any ensuing transactions and the event by which later transactions are judged. Alternatively, a merger may be justified or measured in relation to past transactions by the acquirer.

(3) Case-based decisions: People are reluctant to do full cost/benefit analysis, so they reason from past examples ("representativeness") and take small, incremental, reversible steps.

Comment: This kind of bias may not be very common in mergers, for these are large, irreversible transactions. The representative bias, however, may be exhibited for the reasons stated under the other biases. 


\section{APPENDIX B}

\section{PSYCHOLOGICAL FACTORS FOR DAIMLER/CHRYSLER MERGER, 1998}

\section{Myopia (Impulses) (STRONG)}

Explanation of Chrysler's reasons: "The likelihood that the automotive industry will undergo significant consolidation, resulting in a smaller number of larger companies surviving as effective global competitors."

\section{Bounded Rationality}

\section{a. Loss Aversion (status quo bias) (STRONG)}

The Form F-4 noted that:

Messrs. Schrempp and Eaton believed industry consolidation was likely because of industry overcapacity and the potential benefits of combining automotive companies arising from joint product design, development and manufacturing, combined purchasing, other economies of scale and brand expansion and diversification. In discussing the possibility of a business combination between Daimler-Benz and Chrysler, they considered it essential that their respective companies play a leading role in this process of expected industry consolidation and choose a partner with optimal strategic fit. ${ }^{2}$

Note that the non-employee portion of the board is roughly divided between directors of former companies, and management is also shared. ${ }^{3}$

This transaction is clearly presented as a "merger of equals," which itself highlights the status quo bias: "Daimler/Chrysler AG shall have a corporate governance structure reflecting that the Transactions contemplate a 'merger-ofequals." This structure included shared supervisory and management boards, shared integration committees, and use of both headquarters. This is even more highlighted when the release later states that, as a result of the merger-of-equals, "Chrysler's directors and senior management will be in a position to help bring about the realization of the enhanced growth prospects and synergies expected from the combination of the two companies, for the benefit of stockholders of Daimler/Chrysler AG (including former stockholders of Chrysler)."

b. Extremeness Aversion (STRONG)

\footnotetext{
${ }^{1}$ DAIMlER/ChRYSLER AG, Registration STATEMENT ON FORM F-4 49 (1998).

${ }^{2} I d$. at 46.

${ }^{3} I d$. at 16.

${ }^{4}$ Id.

${ }^{5}$ Id. at 50.
} 
One alternative is for each company to remain independent and pursue its own strategy. But this is suggested to be an almost unthinkable extreme because of industry consolidation, which will result "in a smaller number of larger companies surviving as effective global competitors." A middle alternative is "[t] he Chrysler Board's view that Daimler-Benz was the best partner for a business combination with Chrysler. While each company was strong by itself, the combined company would be stronger than either one individually, because of the two companies' complementary strengths."

This opportunity is presented as "unique": "The Chrysler Board believed that a combination with Daimler-Benz represented a unique strategic opportunity for Chrysler and its stockholders, who could continue to participate as stockholders in the combined company.... Therefore, the Chrysler Board did not seek a transaction with any other company."”

This approach is echoed by Daimler, which points out that "automobile companies that consolidate currently are likely to enjoy the most attractive prospects for materially enhancing their long-term competitive position." ${ }^{8}$ Note that management has no incentive to talk about other merger partners, so as not to give ideas to other parties. However, there is a mention of the ability to consider a "Superior Proposal." The implication also is that other combinations would not have "complementary strengths."

An interesting point on "extremeness" is that the combination is said to reduce the risk of each company operating on its own: "The combination with Chrysler will help reduce the risk associated with the dependency on the premium segment of the automobile market by introducing brand diversity."

\section{c. Over-optimism (STRONG)}

Over-optimism appears throughout the document. One example is Chrysler's reasons for the merger: "The opportunities for significant synergies afforded by a combination of Chrysler and Daimler-Benz-based not on plant closings or layoffs, but on such factors as shared technologies, distribution, purchasing and know-how."10

Moreover, although the risks of the transaction are highlighted (e.g., synergies may not be realized), there is the simple statement that "[t]he Chrysler Board believed that these potential risks and disadvantages were greatly outweighed by the potential benefits anticipated from the Transactions."11 On the

\footnotetext{
${ }^{6} I d$. at 49.

${ }^{7}$ Id.

${ }^{8} \mathrm{Id}$. at 58.

${ }^{9}$ Id.

${ }^{10} \mathrm{Id}$. at 50.

${ }^{11}$ Id. at 51 .
} 
other hand, Daimler quantifies the short and long-term synergies. ${ }^{12}$

\section{d. Hindsight Bias (NOT PRESENT)}

e. Framing Effects

See supra "Loss Aversion" or "Extremeness Aversion."

f. Availability Heuristic

See supra "Myopia" (the focus on industry consolidation).

g. Anchoring (MIDDLE)

Refer to discussion of CSFB's faimess opinion for Chrysler in which CSFB looks at other business combinations. ${ }^{13}$ The same could be said about Goldman Sachs' opinion for Daimler. ${ }^{14}$

h. Case-Based Decisions

Perhaps representativeness is present as in "anchoring" above.

${ }^{12} I d$. at 58.

${ }^{13} \mathrm{Id}$. at 53,56 .

${ }^{14}$ Id. at 60 . 
